\title{
THE GENUS BATHYSCIOLA JEANNEL, 1910 IN THE IBERIAN PENINSULA AND PYRENEES. TAXONOMIC REVISION OF SECTIONS IV, VI AND VII (JEANNEL, 1924) (COLEOPTERA, CHOLEVIDAE, LEPTODIRINAE)
}

\author{
J. Fresneda* y J. M. Salgado-Costas**
}

\begin{abstract}
The taxonomy of the Iberian and Pyrenean species of Bathysciola Jeannel, 1910 (sections IV, VI and VII of Jeannel, 1924) is revised. The proposed ordenation is based on the study of the genital structures of both sexes, in particular the sclerotised shield of the internal sac of the aedeagus. According to the different models of internal sac were identified the following species groups in the genus Bathysciola Jeannel, section IV: aubei group of Peyerimhoff (1 taxon): $B$. aubei (Kiesenwetter); madoni new group (2 taxa): $B$. madoni Jeannel and $B$. penicillata Jeannel; zariquieyi new group (2 taxa): B. zariquieyi zariquieyi Bolívar and B. zariquieyi serratensis Coiffait; section VII or ovata group of Perreau (8 taxa): B. asperula asperula (Fairmaire), B. asperula subasperata (Saulcy) (= intermedia Jeannel), $B$. ovata ovata (Kiesenwetter), $B$. ovata aragonica Coiffait, $B$. ovata catalana Coiffait, $B$. ovata gabasensis Hustache, $B$. simonis (Abeille de Perrin) and $B$. talpa (Normand); section VI: lapidicola new group (4 taxa): B. arcuatipes Jeannel, B. lapidicola lapidicola (Saulcy), B. lapidicola rectipes Coiffait and B. lapidicola simplex Coiffait; meridionalis new group (3 taxa): B. finismillennii sp. n., B. grenieri (Saulcy) and B. meridionalis (J. Du Val) (= nitidula Normand); larcennei new group (2 taxa): B. convena Jeannel new rank and B. larcennei (Abeille de Perrin); schiodtei group of Perreau (9 taxa): B. bigerrica Jeannel new rank (= convexa Coiffait n. syn.), B. breuili Bolívar (= azuai Bolívar n. syn.), B. diegoi Salgado \& Fresneda, $B$. fauveli Jeannel, B. grandis (Fairmaire), B. obermaieri Bolívar, B. parallela (Jeannel), $B$. rugosa (Sharp) and $B$. schiodtei (Kiesenwetter) (= navarica Coiffait). Incertae sedis: Bathysciola aranensis Coiffait and Bathysciola minuscula (Abeille de Perrin).
\end{abstract}

Key words: Coleoptera, Cholevidae, Leptodirinae, genus Bathysciola, revision, Iberian Peninsula, Pyrenees.

\section{RESUMEN}

El género Bathysciola Jeannel en la Península Ibérica y Pirineos. Revisión taxonómica de las secciones IV, VI y VII (Jeannel, 1924) (Coleoptera, Cholevidae, Leptodirinae)

Se realiza una revisión taxonómica de las secciones IV, VI y VII (Jeannel, 1924) con las especies Ibéricas y de los Pirineos del género Bathysciola. Esta propuesta de orde-

\footnotetext{
* Ca de Massa, 25526 Llesp-El Pont de Suert, Lleida, España. E-mail: ffresned@xtec.net

** Dpto. de Biología Animal. Facultad de Biología. Universidad de León. E-24071 León. España. E-mail: dbajsc@unileon.es
}

This study was financed by the "Fauna Ibérica" project (DGICYT PB95-02353 and REN2001-1956-C17-09/GLO). 
nación tiene como base el examen de las estructuras genitales de los dos sexos, y de un modo especial el estudio de la armadura esclerotizada del saco interno del edeago. Se han diferenciado los siguientes grupos de especies en el género Bathysciola Jeannel, section IV: grupo aubei de Peyerimhoff (1 taxon): B. aubei (Kiesenwetter); madoni nuevo grupo (2 táxones): $B$. madoni Jeannel y $B$. penicillata Jeannel; zariquieyi nuevo grupo (2 táxones): $B$. zariquieyi zariquieyi Bolívar y $B$. zariquieyi serratensis Coiffait; sección VII o grupo ovata de Perreau (8 táxones): B. asperula asperula (Fairmaire), B. asperula subasperata (Saulcy) (= intermedia Jeannel), B. ovata ovata (Kiesenwetter), B. ovata aragonica Coiffait, B. ovata catalana Coiffait, B. ovata gabasensis Hustache, B. simonis (Abeille de Perrin) y $B$. talpa (Normand); sección VI: lapidicola nuevo grupo (4 táxones): B. arcuatipes Jeannel, B. lapidicola lapidicola (Saulcy), B. lapidicola rectipes Coiffait y $B$. lapidicola simplex Coiffait; meridionalis nuevo grupo (3 táxones): $B$. finismillennii sp. n., B. grenieri (Saulcy) y B. meridionalis (J. Du Val) (= nitidula Normand); larcennei nuevo grupo (2 táxones): $B$. convena Jeannel, nueva posición en el grupo, y $B$. larcennei (Abeille de Perrin); grupo schiodtei de Perreau (9 táxones): B. bigerrica Jeannel, nueva posición en el grupo (= convexa Coiffait n. syn.), B. breuili Bolívar (= azuai Bolívar n. syn.), B. diegoi Salgado \& Fresneda, B. fauveli Jeannel, B. grandis (Fairmaire), B. obermaieri Bolívar, B. parallela (Jeannel), B. rugosa (Sharp) y $B$. schiodtei (Kiesenwetter) (= navarica Coiffait). Incertae sedis: Bathysciola aranensis Coiffait y Bathysciola minuscula (Abeille de Perrin).

Palabras clave: Coleoptera, Cholevidae, Leptodirinae, género Bathysciola, revisión, Península Ibérica, Pirineos.

\section{Introduction}

Jeannel (1924a) divided the genus Bathysciola Jeannel 1910 into eight sections. The ordenation proposed by this author is based on the geographical distribution and morphological characters, so that species with different models of masculine genitalia, spermathecal complex and occulate or anophthalmic, are grouped together. The only precedent is that Jeannel (1924a) formed his section IV based on the "Bathyscia the aubei group of Peyerimhoff (1905)". The ordenation proposed by Jeannel (1924a) is still valid; the only change made concerns the naming of the sections, which has been replaced by "group species" in the manner of "groupe schiodtei" or other proposals made by Perreau (2000). This genus, which now contains 83 species distributed from the western Pyrenees to the Caucasus could be compared to a sack containing taxa of dubious phylogenetic value. The need for a review of the complex has already been suggested by Vailati (1988) who, with regard to the "Bathysciola complex", states that "... ancora resta in attesa di migliore definizione"; also Giachino (1998) points out that the systematic position of the genus is dubious and is currently being completely restructured. Fresneda \& Salgado (2000) state that the genus Bathysciola appears in several dichotomies of the identification key proposed for Iberian Leptodirinae: this is an extremely heterogenous group which "will probably have to be divided into different genera". Of the sections proposed by Jeannel (1924a) only the fourth, sixth and seventh have Iberian species. The fourth section includes the type species of the genus so this taxon will be taken as the genus model; however, this section includes a number of species distributed in the Provence area (France and Italy) which have not been studied as the aim of this paper is to attempt to order Iberian fauna on both sides of the Pyrenees. The species in this section not found in the Iberian Peninsula will be studied at a later date. The species in the sixth and seventh sections have all been studied, as they are distributed preferably in the Pyrenees; only one species in the sixth section inhabits areas at a considerable distance from the Pyrenees and it has also been studied. The other sections of the genus (sensu Jeannel, 1924a) will be considered some time in the future; the species in these sections are also absolutely heterogenous as regards models of genitalia: the entire genus should perhaps be fragmented into several genera for reasons of coherence.

\section{Material and methods}

The following described species and subspecies have been studied: $B$. aranensis Coiffait, $B$. arcuatipes Jeannel, B. asperula asperula (Fairmaire), B. asperula subasperata (Saulcy) (= intermedia Jeannel), B. aubei (Kiesenwetter), B. azuai Bolívar, 
B. breuili Bolívar, B. diegoi Salgado \& Fresneda, $B$. fauveli Jeannel, $B$. finismillennii sp. n., $B$. grandis (Fairmaire), B. grenieri (Saulcy), B. lapidicola lapidicola (Saulcy), B. lapidicola rectipes Coiffait, $B$. larcennei convena Jeannel, $B$. larcennei larcennei (Abeille de Perrin), B. lapidicola simplex Coiffait, B. madoni Jeannel, B. meridionalis (J. Du Val) (= nitidula Normand), $B$. minuscula (Abeille de Perrin), B. obermaieri Bolívar, B. ovata aragonica Coiffait, $B$. ovata catalana Coiffait, $B$. ovata gabasensis Hustache, $B$. ovata ovata (Kiesenwetter), $B$. parallela bigerrica Jeannel, B. parallela parallela (Jeannel), B. penicillata Jeannel, B. rugosa (Sharp), $B$. simonis (Abeille de Perrin), B. schiodtei convexa Coiffait, B. schiodtei schiodtei (Kiesenwetter) (= navarica Coiffait), B. talpa (Normand), B. zariquie$y i$ serratensis Coiffait and $B$. zariquieyi zariquieyi Bolívar.

The aim of this study is to characterize the different models of internal sac of the aedeagus and to group together those species corresponding to this criterion to provide data for a future ordenation; however, a new generic category has not been established as this should be done as part of a revision of the whole genus. The characterised models are determined by different sclerotized pieces, their shape and position in the sac: support and copulatory pieces (Dupré, 1992). Other genital characters, such as the number of setae on the tip of the lateral style of the aedeagus or the median lobe itself, have been added to this criterion. There is no doubt about the validity of using the internal sac of the aedeagus to form natural groups and this as been used by several authors since Jeannel (1910), who used these characters in the first reordenation of "Silphides cavernicoles". Jeannel (1911) insists that these structures could be the basis for systematic ordenations; therefore, they enable the phylogenetic history of the species in question to be restructured. He states that each species has a consistent and specific copulatory shield corresponding to «... en quelque sorte à la signature d'une série phylétique» (Jeannel, 1922). Jeannel (1924a) published his revision of the Bathysciinae Horn 1880 , giving a general description of the different models of internal sac on which he based his proposed ordenation. Jeannel (1950) proposed the ordenation of the genus Speonomus Jeannel 1908, based on the tip of the lateral style. Finally, Jeannel (1955) established what is considered to be the most primitive division of the Bathysciinae: "supraflagellates" and "infraflagellates". A decade later Laneyrie (1967, 1969 and 1978) proposed a new ordenation based on the copulatory shield of the internal sac, basically the structures in the basal region. Guéorguiev (1974a, 1974b and 1976) proposed a new ordenation using the external morphology: the series of combs and spurs on the tibiae. He established dichotomies for four genera only, based on the parts of the aedeagus. Bellés et al. (1978) proposed a new ordenation for the Iberian species using studies by Jeannel, Laneyrie and Guéorguiev, and they basically use the characters of the male genital structures (internal sac, tip of the lateral style, etc) to include new records on Iberian fauna. Bellés (1983) first used the characters of the internal sac of the aedeagus to establish a dichotomy between Speonomus puncticollis Jeannel 1910 and S. espinosai Bellés 1983. Bellés (1984) carried out a detailed study of the internal sacs of two species in the genus Parvospeonomus Bellés \& Escolà 1977 and also established the naming of their different pieces. In studies by Bellés, or later, Bellés \& Comas (1986), the need for a revision of the species of Iberian Leptodirinae is underlined in the light of a detailed study of the characters of the internal sac of the aedeagus. With these criteria Comas \& Escolà (1989) described the subgenus Ceretophyes Comas \& Escolà 1989, and Comas (1983) reviewed the genus Anillochlamys Jeannel 1909. Following the same line Dupré (1989, 1990 and 1991) reviewed and ordered the Leptodirinae from the western confines of the Pyrenees until, in 1992, he presented an ordenation based on a detailed and very complete study of the internal sac of the aedeagus; he also redefined the divisions proposed by the previously-mentioned researchers (Dupré, 1992). Fresneda \& Hernando (1994) and Fresneda et al. (1994) used the same method to describe the genus Bellesia Fresneda \& Hernando 1994 and the subgenus Naspunius Fresneda, Hernando \& Lagar 1994. Salgado (1975, 1993, 2000) ordered the Iberian supraflagellates in the series Quaestus Schaufuss 1861 and Speonomidius Jeannel 1924 in groups of species with the same model of internal sac of the aedeagus; Fresneda (1998) and Fresneda \& Salgado (2000) did something similar with the Iberian "infraflagellates". Also in the same line is the latest revision of the series Spelaeochlamys (= section Anillochlamys) by Salgado \& Fresneda (2003). The latter studies (Salgado, 2000, Fresneda, 1998 and Fresneda \& Salgado, 2000) also consider some elements of the female genitalia -in the line of Perreau (1989)- adding observations on characters that had not previously been studied: detailed structure of the spermathecal complex (length and thickness of the spermathecal duct, type of insertion in the sper- 
matheca and in the bursa copulatrix); this is an open line of investigation with few available data, but which appears to be quite promising. In summary, in the last hundred years numerous authors have proposed various ordenations based on different characters to reflect the phylogeny of a group; these contributions have been complementary in some cases and contradictory in others, but all of them make the debate more interesting. The constant increase in described taxa underlines the need to search for new characters or reinterpret traditionally used ones. Following this line of work, Bellés (1984) consolidated the basis of the study of the sclerotised shield of the internal sac of the aedeagus; it has also been followed by different authors including Fresneda et al. (in press) who demonstrated that these are the most consistent characters when establishing phylogenetic relationships based on a binary matrix with multiple characters according to the cladistic method used. In any case, this paper does not include a phylogenetic study to establish relationships between the different groups of species; its aim is to define groups that will provide a reasonably simple identification of the species. In a later study, which has already been started, an effort will be made to establish relationships between these taxa and other genera of Leptodirinae inhabiting the same regions.

All the insects in this study should be included in the Leptodirinae infraflagellates. Contributions by Jeannel (1924a, 1955), Laneyrie (1967), Guéorguiev (1974a, b and 1976), Casale et al. (1991) and Giachino et al. (1998) are considered, but the meaning given to the term infraflagellates is that contributed by Dupré (1992) who redefines this group based on the study of histological sections of the internal sac of the aedeagus: models of internal sac with a Y-shaped piece in the basal region, and dorsal phanerae in the median region. The spermathecal complex in all these genera correspond to "type 1" of the spermatheca defined by Perreau (1989).

The terminology used to designate the different pieces of the copulatory shield of the internal sac of the adeagus according to the denominations established by Bellés (1984), Bellés \& Comas (1986), Dupré (1992) and Fresneda (1998). For each model the situation and name of the structures considered are indicated in the corresponding illustration. Whenever necessary, a new name is included if there is no equivalent piece in the quoted referente (see Figs. 1, 5, 12, 15, 31, 42, 48, 80).

As for the specific identity of the taxa of a determined group, all those species with differences in the genital structures have been considered as different species, and those with identical genitalia but different external morphology as subspecies. These criteria are argueable, however an effort has been made to apply an aseptic system to give some coherence to the proposed ordenation and mimimize as far as possible the observer's own perception. There are several subspecies described and in most cases the description is based on a small number of specimens, often only one; an effort has been made not to directly establish synonymies with the respective nominotypic subspecies as the person responsable for the description did not consider the constancy of the differential characters in question in a population; this is also the reason why there are not enough data to deny the validity of these taxa; all the subspecific names in the same situation have been kept in the hope that future samplings will shed some light.

Abbreviations.- Ar., Ariège; BI, Vizcaya; B. Pyr., Basses Pyrénnees; ICZN, International Code of Zoological Nomenclature; S, Spain; F, France; GI, Girona; P. Or., Pyrénnees Orientales; HC, Henri Coiffait; H. Gar., Haute Garone; i, impreso; JF, Javier Fresneda; L, Lleida; MNCNM, Museo Nacional de Ciencias Naturales de Madrid; MNHNP, Musée National d'Histoire Naturelle de Paris; hw, handwriting; MZB, Museu de Zoologia de Barcelona; NA, Navarra; OE, Oleguer Escolà; RJ, René Jeannel; SS, San Sebastián; V, Vaucluse; VI, Álava.

\section{Results and discussion}

Genus Bathysciola Jeannel, 1910

Catopsinus Motschulsky, 1868. Horae Soc. entomol. Ross., 6: 58 Bathysciola Jeannel, 1910. Arch. Zool. exp. gén., 45(1): 9

TYPE SPECIES: Bathyscia aubei Kiesenwetter, 1850

The model of male genitalia and spermatheca of the genus is that belonging to Bathysciola aubei (Kiesenwetter), described in the section on the species.

Section IV of Jeannel, 1924

Bathysciola Sectio IV of Jeannel, 1924. Arch. Zool. exp. gén., 63(1): 104

The Bathysciola species lacking transverse striolae on the elytra but with a sutural stria not parallel to the suture were grouped together by Jeannel (Jeannel, 1924a) and named section IV. This section includes the true Bathysciola as it includes the type species of the genus; in the 
Iberian Peninsula there are three species, belonging to two groups. In his check list Perreau (2000) establishes the correspondence between "Bathysciola Section IV Jeannel, 1924" and "Groupe aubei of Peyerimhoff, 1905"; in this study the two categories are maintained because although $B$. madoni, $B$. penicillata and $B$. zariquieyi do, in fact, belong to section IV, they cannot be included in the same group as $B$. aubei.

\section{The aubei group of Peyerimhoff, 1905}

Groupe aubei of Peyerimhoff, 1905. Bull. Soc. entomol. Fr., 10: 297

DiAGNOSIS. Characterised by the internal sac of the aedeagus (Fig. 1) which has a robust strongly sclerotized axial piece (Fig. 1: AP) and U-shaped phanerae (Fig. 1: UP) on both sides and identical, strongly sclerotized nodules (Fig. 1: SN) near the base of the phanerae; at the base of the reinforcing bands (Fig. 1: ARB) there are oblique phanerae (Fig. 1: OP) but no membranous ligulae or sclerotized nodules. The tip of the lateral style of the aedeagus has three setae (Fig. 3).

GeOgRAPHICAL Distribution. The Bathysciola of the group aubei are distributed in the Provence area, all the Golfe du Lion to northern Italy.

\section{Bathysciola (Bathysciola) (aubei group) aubei} (Kiesenwetter, 1850)

Bathyscia aubei Kiesenwetter, 1850. Stettiner entomol. Ztg., 11(7): 223

Adelops epuraeoides Fairmaire, 1869. Stettiner entomol. Ztg., 30: 231

Bathyscia epuraeoides Fairmaire: Abeille de Perrin, 1882. Rev. Entomol. Caen, 1: 18

Adelops aubei (Kiesenwetter): Miller, 1885. Verh. Zool.-botan. Ges. Wien, 5: 508

Bathyscia (Bathyscia) aubei Kiesenweter: Reitter, 1885. Verh. naturforsch. Ver. Brünn, 23(1884): 25

Bathyscia (Bathyscia) epuraeoides Fairmaire: Reitter, 1885. Verh. naturforsch. Ver. Brünn, 23(1884): 25

Bathysciola aubei (Kiesenwettter): Jeannel, 1910. Arch. Zool. exp. gén., 45(1): 27

Bathysciola (Bathysciola) aubei (Kiesenwetter): Jeannel, 1914. Coleopterorum catalogus pars 60: 7

Bathysciola aubei var. epuraeoides (Fairmaire): Jeannel, 1910. Arch. Zool. exp. gén., 45(1): 27

Bathysciola (Bathysciola) aubei var. epuraeoides (Fairm.): Jeannel, 1914. Coleopterorum catalogus pars 60: 7

Bathysciola nerusorum Fagniez, 1922. Bull. Soc. entomol. Fr., 27: 317

Bathysciola aubei var. nerusorum Fagniez, 1922: Jeannel, 1924. Arch. Zool. exp. gén., 63(1): 104

Bathysciola aubei aubei (Jeannel): Bonadona, 1985. l'Entomologiste, 41(1): 3
Bathysciola (Bathysciola) aubei (Kiesenwetter): Perreau, 2000. Mém. de la SEF, 4: 224

Material studied.- F-V, Avignon, Vareilles leg., 7 exs. (col. MZB).

Male Genitalia. Median lobe of aedeagus (Fig. 2) robust and, in lateral view, curved almost in a right angle, one third from the tip; apical third weakly sinuous; lateral style as long as median lobe; fine, curved pointed and bearing 3 setae inserted in distal extreme (Fig. 3); internal sac of aedeagus (Fig. 1) with very long basal region, Y-shaped piece with fine, long arms; median region with long, strong and sclerotized axial piece, exhibiting U-shaped phanerae on both sides, with one arm robust and folded back on itself and the other fine; two similar very sclerotized nodules near base of phanerae; reinforcement bands in apical region short, wide with one fine oblique phanera at base.

Female Genitalia. Spermatheca (Fig. 4) short, robust and folded in right angle; both lobes practically joined together as the hyaline median region is quite small; very developed basal lobe; thick spermathecal duct not forming nodule at insertion point.

Discussion. A series of specimens from Avignon (France) was used for the description and illustrations. This taxon is the type species of the genus, so the model of genitalia described is that identifying the genus. No data is given on presumibly related species outside the Iberian distribution area -those in section IV- as they are yet to be studied. The Iberian specimens in the section, although coinciding with aubei in the type of elytral sculpture and the fact that their sutural stria is not parallel to the suture, their respective internal sacs are considerably different. Also, the tip of the lateral style has three setae in aubei and always between 5 and 14 in the others (B. madoni, B. penicillata and $B$. zariquieyi), depending on the species. The differences are so considerable that when revising the remaining taxa in section $\mathrm{IV}$, the Iberian species at least, may form a new genus. Affinities with $B$. $a u b e i$, and therefore the genus, are probably found amongst the Leptodirinae Provence distribution: the Alps and northern part of the Italian peninsula. There are five subspecies in the aubei complex (Perreau, 2000).

\section{The madoni new group}

Diagnosis. This group of species is characterised by strongly sclerotized U-shaped piece (Fig. 5: UP) in the internal sac of the aedeagus (Figs. 5 and 
a

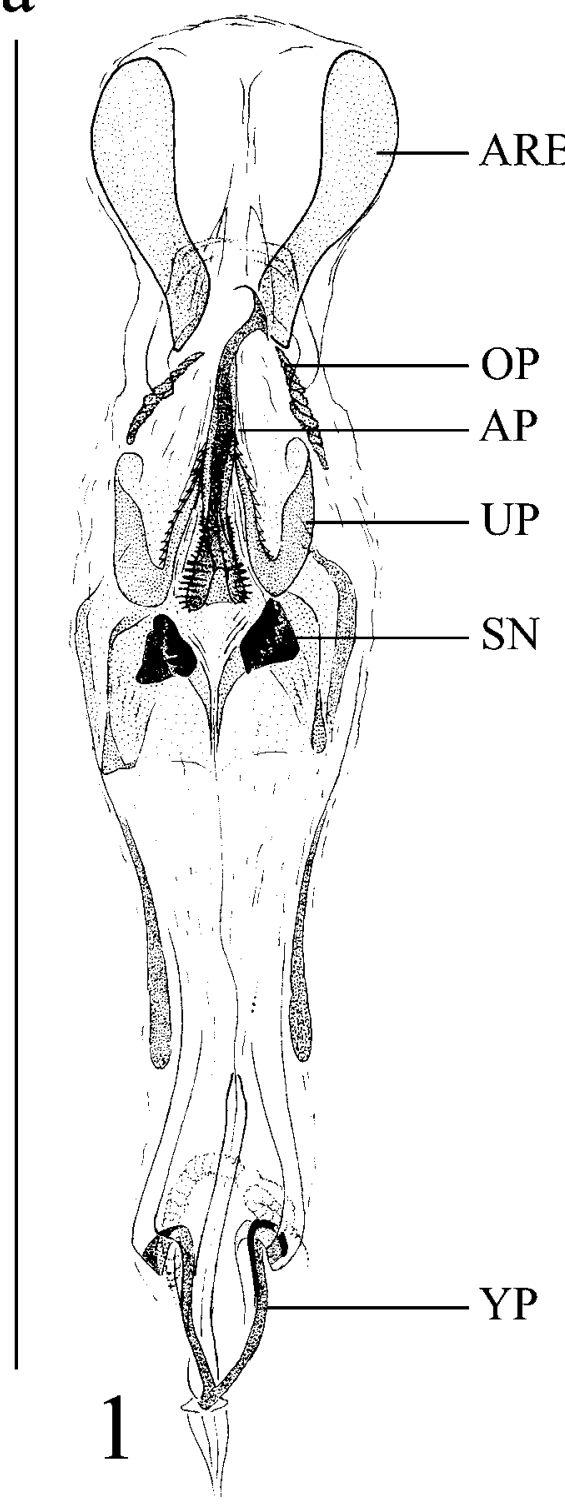

b

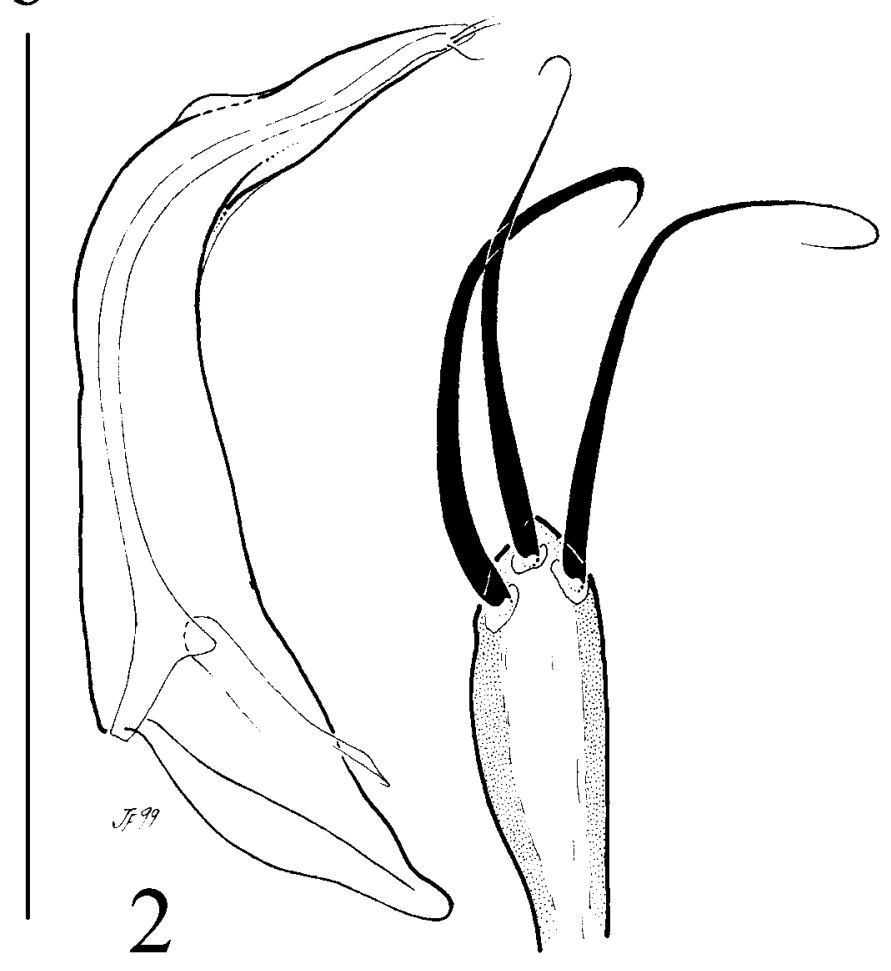

3

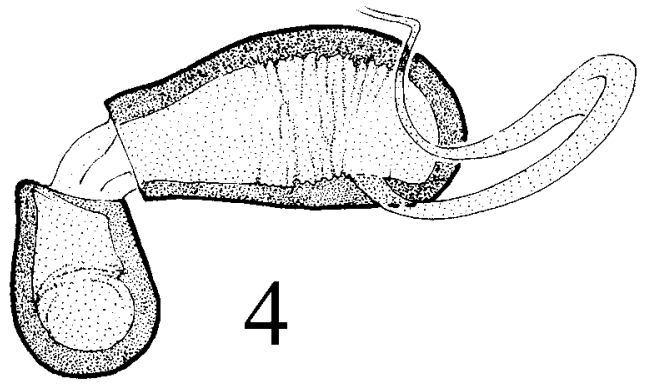

$\mathrm{C}$

Figs. 1-4.- Bathysciola (Bathysciola) aubei. 1) internal sac of the aedeagus in dorsal view. 2) aedeagus in lateral view. 3) apical region of the lateral style. 4) spermatheca. Scale bar: a-b, $0.5 \mathrm{~mm}: 1,2 ; \mathrm{c}, 0.1 \mathrm{~mm}$ : 4. AP, axial piece; ARB, apical reinforcement band; OP, oblique phanerae; UP, U-shaped phanerae; SN, sclerotized nodule; YP, Y-shaped piece.

Figs. 1-4.-Bathysciola (Bathysciola) aubei. 1) visión dorsal del saco interno del edeago. 2) visión lateral del edeago. 3) región apical del estilo lateral. 4) espermateca. Escala: a-b, $0.5 \mathrm{~mm}: 1,2$; c, $0.1 \mathrm{~mm}$ : 4. AP, pieza axial; ARB, banda de refuerzo apical; OP, fanera oblicua; UP, fanera en forma de U; SN, nódulo esclerotizado; YP, pieza en forma de Y. 

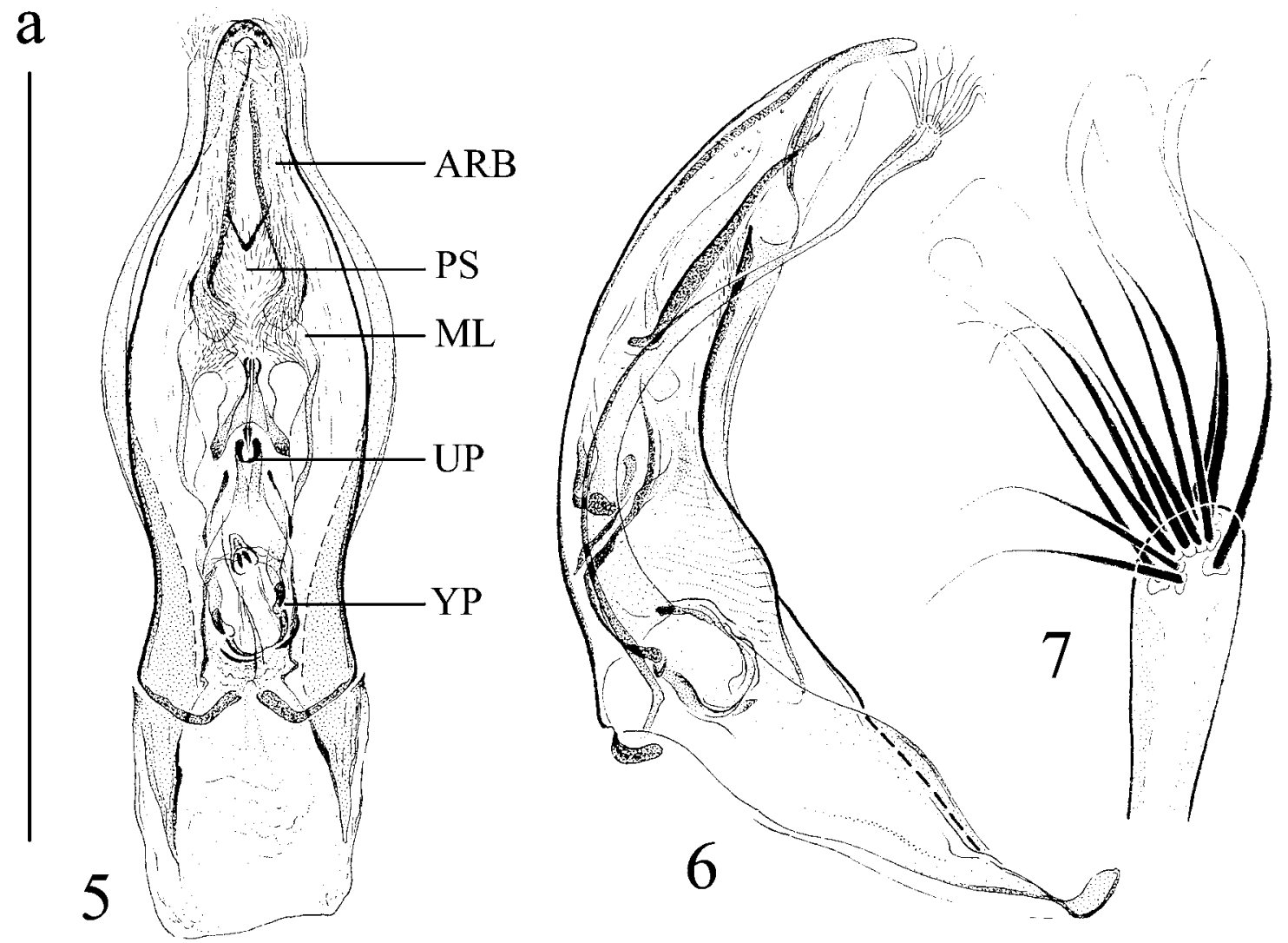

Figs. 5-7.- Bathysciola (Bathysciola) madoni. -5) aedeagus and internal sac in dorsal view. 6) aedeagus in lateral view. 7) apical region of the lateral style. Scale bar: a, $0.5 \mathrm{~mm}: 5,6$. ARB, apical reinforcement band; ML, membranous ligulae; PS, pilose sac; UP, U-shaped phanerae; YP, Y-shaped piece.

Figs. 5-7.-Bathysciola (Bathysciola) madoni. -5) edeago y saco interno en vista dorsal. 6) vista lateral del edeago. 7) región apical del estilo lateral. Escala: a, $0.5 \mathrm{~mm}: 5$, 6. ARB, banda de refuerzo apical; ML, lígula membranosa; PS, saco piloso; UP, fanera en forma de U; YP, pieza en forma de Y.

8), where the hyaline axial piece originates; no differentiated (sclerotized) phanerae in median region, reinforcement bands (Fig. 5: ARB) resting upon membranous ligulae (Fig. 5: ML); amongst the apical reinforcement bands there is a sac covered in pilosity (Fig. 5: PS). The tip of the lateral style of the aedeagus is armed with 8-14 setae. Two species.

GEOGRAPHICAL DistribUtion. The species in the madoni group are found in the northern peninsula area, from the north of the western Pyrenees to the pre-Pyrenean mountains in the south, in interior regions of Catalonia; there are not many data on captures and their distribution areas are marked by a number of collection points at a considerable distance from each other.

\section{Bathysciola (Bathysciola) (madoni group) madoni} Jeannel, 1923

Bathysciola madoni Jeannel, 1923. Bull. Soc. entomol. Fr., 28: 104

Bathysciola (Bathysciola) madoni Jeannel, 1923: Jeannel, 1924. Arch. Zool. exp. gén., 63(1): 109

Bathysciola (Bathysciola) madoni Jeannel: Perreau, 2000. Mém. de la SEF, 4: 227

Material STUDIED AND BIBliographical Data. The description of the species indicates that there were three specimens in the type series, one male and two females: "Types: un mâle et deux femelles..." (Jeannel, 1923); in the MNHNP general collection, but there are, in fact four, all from the same locality. One of them, the only male, has the "type" red label. This specimen is labelled as follows: 1. (hw): Prats de Mollo / 4.18. Tourau; 2. (hw) R. Madon; 3. (i): TYPE; 4. (i): MUSÉUM PARIS / Coll. R. Jeannel 1931; 5. (hw): Madoni / 
Je. The other three specimens are females. Two of them are considered syntypes. The first because it has the same collection inscription as the male, "Tourau"; and the second because it has "feuilles" written on it, and the original description states: “... , en tamisant des feuilles, ..." (Jeannel, 1923). The third one is not included in the type series because it bears the word "piquets", a term that does not appear in the description by Jeannel. First specimen: 1. (hw): Prats de Mollo / 77 Tourau; 2. (i): MUSÉUM PARIS / Coll. R. Jeannel 1931. Second specimen: 1. (hw): Prats de Mollo / 21.7 feuilles; 2. (i): MUSÉUM PARIS / Coll. R. Jeannel 1931; 3. (hw): Madoni. The third female, which does not form part of the type series, is labelled as follows: 1. (hw): Prats de Mollo / 7.7- piquets; 2. (i): MUSÉUM PARIS / Coll. R. Jeannel 1931. Two males and one female from the MZB collection, labelled by R. Jeannel himself and collected by R. Madon have been studied: 1. (hw) Prats de Mollo / 23-VIII Madon; 2. (hw) Bathysciola / (hw) madoni / (hw) Jeannel / (i) R. JEANNEL det. After reviewing the material referred to in bibliographical references: S-B, Puigsacalm, 22.VII.1951, Montada leg. (Lagar, 1954; Español, 1956); S-B, Montesquiu, X.1934, Español leg. (Lagar, 1954; Español, 1956); S-GI, Camprodón (Español, 1956). The following specimens are in the col. Coiffait preserved at the MNHNP: S-GI, Ripoll, 28.XII.1955, HC leg., 1 ex.; 19.V.1956, HC leg., 4 exs. (Coiffait, 1959); S-GI, Ribes de Fresser, 2.XI.1955, HC leg., 1 ex.; 26.XII.1955, HC leg., 4 exs.; 5.IV.1956, HC leg., 12 exs. (Coiffait, 1959).

Male Genitalia. Median lobe of aedeagus in dorsal view with mid region expanded (Fig. 5); in lateral view (Fig. 6) uniformly arcuate from one end to the other and of uniform thickness, even the apical third. The tip of the lateral style of the male of the type series (Fig. 7) bearing twelve arcuate setae of similar length. Internal sac (Fig. 5) with symmetrical branches of Y-shaped piece prolonged over sides of the sac to median region where they come into contact with the appendage of the dorsal sacs; strongly sclerotized U-shaped piece where the axial piece originates; there is a sac densely covered in fine pilosity amongst the reinforcing bands, and another one covered in small thick spines between the hyaline protruberances of the Y-shaped piece; V-shaped piece amongst reinforcing bands.

Discussion. The male genitalia of a specimen from Prats de Mollo in France was illustrated. With regard to $B$. aubei, the differences are enormous, especially in the internal sac of the aedeagus; the genital structures of these two taxa cannot be considered as belonging to the same model (Figs. 1 and 5). B. madoni is extremely similar to B. penicillata. The difference between these species is not very clear. The specimens collected in the area of Ripollès (Gerona) were identified as $B$. penicillata by Jeannel (preserved in the MNHNP general collection) and B. madoni by Coiffait (Coiffait, 1959); the latter author points out that the number of setae on the tip of the lateral style of the aedeagus varies considerably (eight to fourteen), which was perhaps the main character justifying the description of $B$. penicillata; it was also discovered that the lateral style preserved from the single type specimen of $B$. penicillata has ten setae in the distal extreme, and not nine as indicated in the description. The internal sac of both species is very similar, but the median lobe is quite different in lateral view: uniformly arcuate in $B$. madoni (Fig. 6) and subrectilinear with the apical third sinuous in B. penicillata (Fig. 9). The determination of all the Iberian references of this species should be reviewed as it is highly likely that many specimens classified as $B$. madoni are in fact B. penicillata. The genitalia of the male of the type series was extracted from the glass slide cover and prepared again on an acetate paper slide placed in Canada Balsam and inserted on the same pin as the specimen it belongs to; the two lateral styles had been separated from the median lobe by R. Jeannel.

\section{Bathysciola (Bathysciola) (madoni group) penicillata} Jeannel, 1924

Bathysciola penicillata Jeannel, 1924. Treb. Mus. Ciènc. nat. Barcelona, 4(8): 11

Bathysciola (Bathysciola) penicillata Jeannel, 1924: Jeannel, 1924. Arch. Zool. exp. gén., 63(1): 109

Bathysciola (Bathysciola) penicillata Jeannel: Perreau, 2000. Mém. de la SEF, 4: 228

Material STUDIED. The original description indicates the existence of only one male designated. "Type: un mâle..." (Jeannel, 1924b). This specimen is stored in the MNHNP general collection and labelled as follows: 1.: (i) CATALUÑA / (hw) Llinas-Berga / (i) Zariquiey; 2. (i, in red) TYPE; 3. (i): MUSÉUM PARIS / Coll. R. Jeannel 1931; 4. (hw): penicillata / Jeann. The following specimens determined by R. Jeannel are also in the MNHNP general collection: España, Girona, route Ripoll-Vic, VIII.1957, Franz leg., 6 exs. The following specimens identified as B. madoni: S-B, Vidrà, Ermita de Sant Bertomeu, 3.X.1948, Español leg., 2 males and 2 females (Español, 1956) from the MZB col. have been studied. Also the following material collected: S-L, Llinàs, Sant Pere de Graudescales, 21.4.2000, JF and Escoll leg., 2 females; tr.: 6.12.2001/10.11.2002, Escoll and JF leg., 16 males and 5 females.

Male Genitalia. Observed laterally, median lobe of aedeagus (Fig. 9) arcuate in basal two thirds, a thick area, whereas the apical third is sinuous and gradually decreasing to the tip, with a small depression in the dorsal face; distal extreme slightly prolonged and peak-shaped. Lateral style fine, slender, almost as long as median lobe with tip inflated in the shape of an elyptic club, armed with ten long setae (Fig. 10). Internal sac (Fig. 8) with 
a

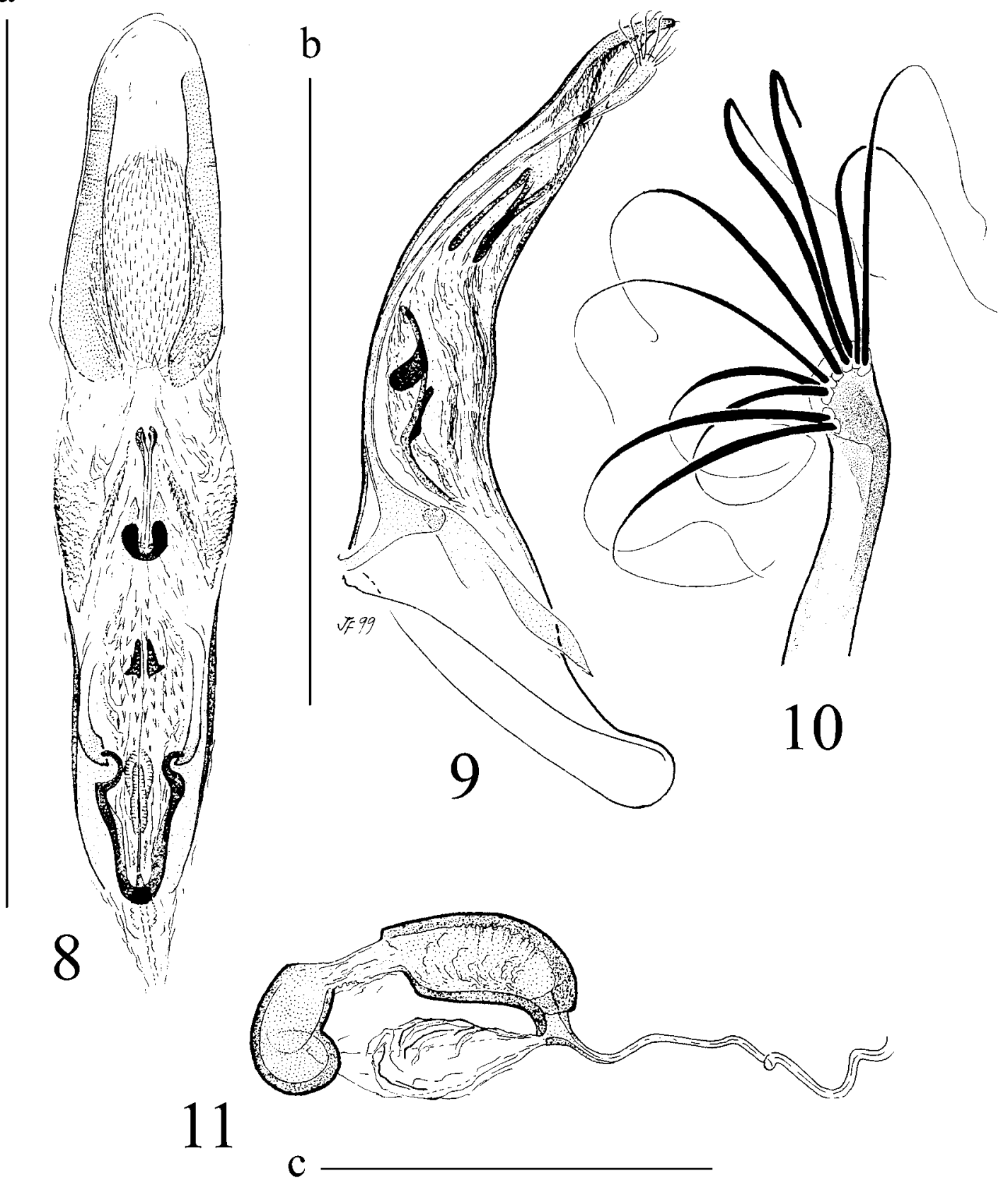

Figs. 8-11.-Bathysciola (Bathysciola) penicillata. 8) internal sac of the aedeagus in dorsal view. 9) aedeagus in lateral view. 10) apical region of the lateral style. 11) spermatheca. Scale bar: a-b, $0.5 \mathrm{~mm}: 8,9 ; \mathrm{c}, 0.1 \mathrm{~mm}: 11$.

Figs. 8-11.- Bathysciola (Bathysciola) penicillata. 8) vista dorsal del saco interno del edeago. 9) vista lateral del edeago. 10) región apical del estilo lateral. 11) espermateca. Escala: a-b, $0.5 \mathrm{~mm}: 8,9$; c, $0.1 \mathrm{~mm}: 11$. 
symetrical branches of the Y-shaped piece prolonged along the sides of the sac to median region where they come into contact with the appendix of the dorsal sacs; strongly sclerotized U-shaped piece where the axial piece begins; sac densely covered in fine pilosity between the reinforcing bands and another covered in thick small spines between the hyaline prolongations of the Y-shaped piece.

Female Genitalia. Spermatheca (Fig. 11) curved throughout, both lobes much larger than median region.

Discussion. Jeannel (1924b) described this species from one specimen. The genitalia of this specimen was prepared between two slides; it is completely flattened laterally and one of the lateral style is separated; it was prepared again on an acetate paper slide in Canada Balsam and inserted on the same pin as the specimen it belongs to. Only the tip of the lateral styles of this specimen was illustrated (Fig. 10) as the rest is completely deformed; the remaining structures weren illustrated using the type locality specimens. The number of setae on the lateral style of the aedeagus varies considerably and overlaps with the number of setae in B. madoni. Only the shape of the median lobe of the aedeagus enables the correct determination, which has already been indicated in the discussion on B. madoni.

\section{The zariquieyi new group}

Diagnosis. This group is characterised by the internal sac of the aedeagus (Fig. 12) with evident ventral phanerae (Fig. 12: VPM), and very small dorsal ones (Fig. 12: DPM) prolonged until coming into contact with the Y-shaped piece (Fig. 12: YP); apical reinforcing bands (Fig. 12: ARB) resting upon membranous ligulae (Fig. 12: ML) whose tegument is densely covered in spines; these ligulae have a sclerotized peduncle in the inferior region. The tip of the lateral style of the aedeagus armed with 5-6 setae. Only one species with two subspecies. The term "group" is used though we are dealing with only one species in coherence with the proposed ordenation.

GeOgRAPHiCAL Distribution. Distributed in mountains situated on the Catalonian coast.

\section{Bathysciola (Bathysciola) (zariquieyi group) zariquieyi zariquieyi Bolívar, 1919}

Bathysciola (Bathysciola) zariquieyi Bolívar, 1919. Butll. Inst. cat. Hist. nat., 19: 18
Bathysciola Zariquieyi Bol.: Lagar, 1954. Speleon, 5(4): 250

Bathysciola (Bathysciola) zariquieyi zariquieyi Bolívar: Perreau, 2000. Mém. de la SEF, 4:

Material STUdied AND BIBLIOGRAPHICAL DATA. In the original description (Bolívar, 1919) the number of specimens studied is not given. "Type: one specimen male from Vallvidrera (Barcelona)" (Bolívar, 1919); although besides the type locality, Vallvidrera, there is also material from: Vilafranca del Penedès and Montseny (Bolívar, 1919). Two specimens from the type series were located. First specimen: 1.: (i) CATALUÑA / (hw Bolívar) Vallvidrera 1916 / (i) Zariquiey; 2.: (hw Bolívar) Bathysciola zariquieyi C. Bol. TIPO. Second specimen: 1.: (i) CATALUÑA / (hw) Montseny 9.VI-16 / (i) Zariquiey; 2. (hw Bolívar): Bathysciola / zariquieyi / Co-Tipo. C. Bol.; 3. (i): MUSÉUM PARIS / Coll. R. Jeannel 1931. The following specimens in the MNCNM, MNHNP and MZB collections have also been studied: S-B, Sant Celoni, Santa Fe del Montseny, X.1959, Español leg., 1 ex. (col. MZB) (Español, 1956); S-B, Mosqueroles (labelled Muscarolas), 20.IX.1927, Zariquiey leg., 2 exs. (1 ex. in col. MZB; 1 ex. in col. Coiffait in MNHNP); S-B, Vidrà, San Bartolomé, 12.X.1950, Mateu leg., 4 exs. (3 in the general collection and 1 in the col. Coiffait, MNHNP); S-GI, Calonge, 2.I.1960, HC leg., 1 ex. (col. Coiffait in MNHNP); S-GI, Llagostera, 1.I.1960, HC leg., 1 ex. (col. Coiffait in MNHNP); S-GI, Tossa de Mar, 27.XII.1960, HC leg., 1 ex., (col. Coiffait in MNHNP); S-L, Rocallaura, Mas de Xaxars, 1 ex. (MNCNM col and another specimen in the MNHNP) (Español, 1956). In the MNHNP general collection there is another specimen labelled with a subspecies name which was never published. The specimen was collected by F. Español; R. Zariquiey studied the insect, as seen on a label written in his own handwriting; he must have thought it was a new taxon and probably sent the specimen to Jeannel to consult him; Jeannel added the insect to the specimens of B. zariquieyi: S-B, Montesquiu, X.1934, Español leg., 1 ex.; has the following label handwritten by Zariquiey: Bathysciola madoni ssp. juncadellai Zar. B. zariquieyi was recorded from the following localities: S-B, Vallvidrera, IV.1925, Zariquiey leg. (Bolívar, 1919; Lagar, 1954; Español, 1956); S-B, Vilafranca del Penedés, 24.VI.1917, Zariquiey leg. (Bolívar, 1919; Lagar, 1954; Español, 1956); S-B, Montseny, 8.VI.1916, Zariquiey leg. (Bolívar, 1919; Lagar, 1954).

MALE GENITALIA. In lateral view, median lobe of aedeagus (Fig. 13) arcuate in basal two thirds, which are more or less thick, in apical third lobe subrectilinear or sinuous and decreasing uniformly to tip; there may be a small depression on the dorsal face; distal extreme pointed or peak-shaped. Lateral style fine, slender, shorter or as long as median lobe and with tip inflated in the shape of an elyptic club bearing five setae, two longer and three shorter (Fig. 14). Internal sac (Fig. 12) with symetrical branches of the Y-shaped piece prolonged along sides of the sac to median region where they come into contact with a quadrangular sclerotized piece; two large sacs covered in spines at base of apical region.

Discussion. The internal sac of the aedeagus of one specimen of the type series was extracted and 

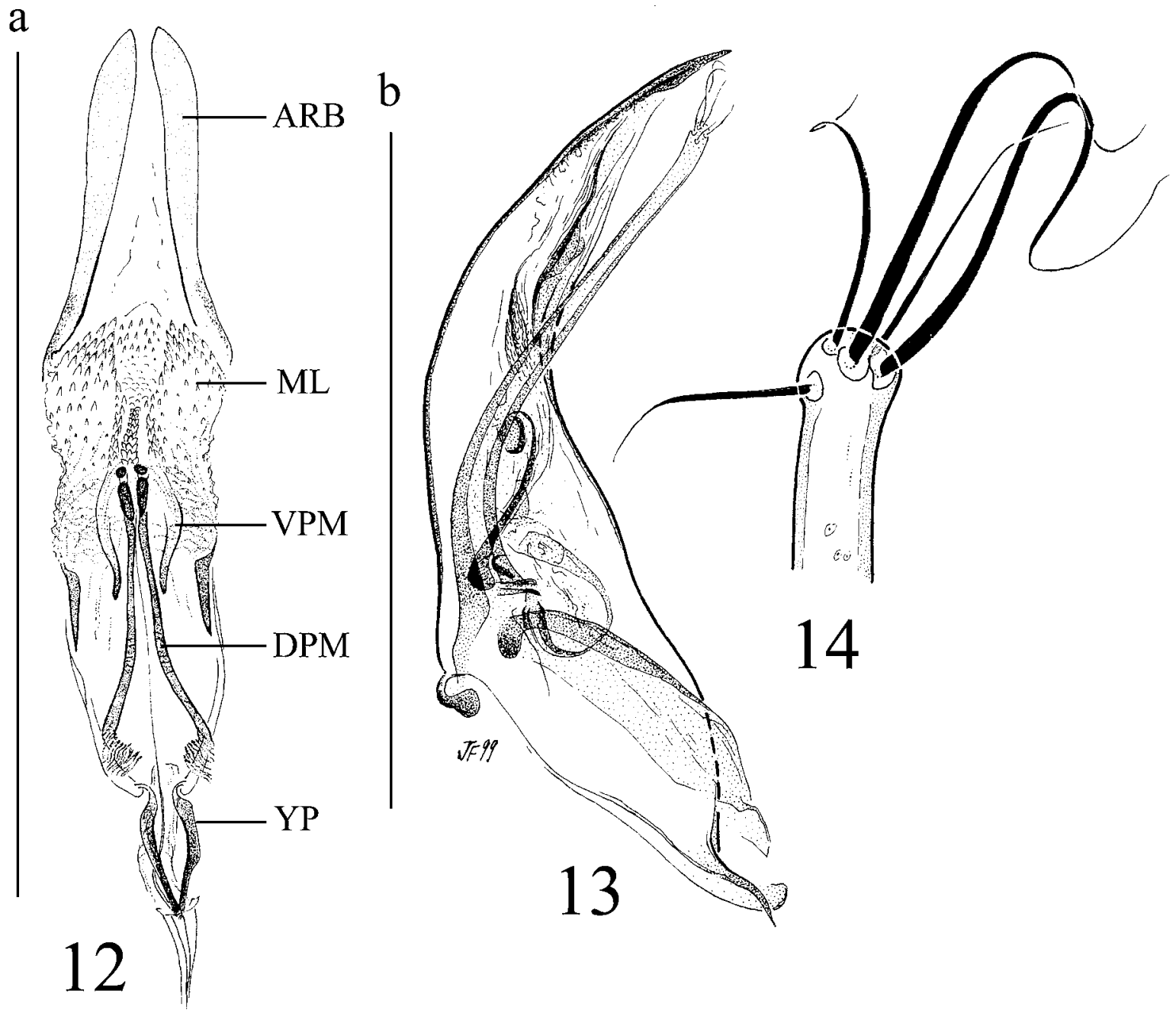

Figs. 12-14.-Bathysciola (Bathysciola) zariquieyi. 12) internal sac of the aedeagus in dorsal view. 13) aedeagus in lateral view. 14) apical region of the lateral style. Scale bar: $0.5 \mathrm{~mm}$. ARB, apical reinforcement band; DPM, dorsal phanerae of the medial region; ML, membranous ligulae; VPM, ventral phanerae of the medial region; YP, Y-shaped piece.

Figs. 12-14.- Bathysciola (Bathysciola) zariquieyi. 12) vista dorsal del saco interno del edeago. 13) vista lateral del edeago. 14) región apical del estilo lateral. Escala: $0.5 \mathrm{~mm}$. ARB, banda de refuerzo apical; DPM, fanera dorsal de la región media; ML, lígula membranosa; VPM, fanera ventral de la región media; YP, pieza en forma de Y.

the two lateral styles separated; it is prepared between two glass slides, and separated from the specimen it belongs to. In the illustrations, the internal sac of the aedeagus and tip of the lateral style belong to this specimen, whereas the other structures were illustrated from a specimen from the Montseny massif. The original description (Bolívar, 1919) indicates that the tip of the lateral style of the aedeagus has five setae, two longer and three shorter ones; the datum is correct for the two lateral styles of the studied male of the type series, but Jeannel (1924a, b) states that the specimens he studied have six. This taxon is quite isolated; the internal sac of its aedeagus is very different to that of the other Iberian species in section IV. It should probably have its own genus, but this division should be made from the perspective of a revision of the genus, especially the species in section IV. For the moment, no taxonomical changes are to be made. 
a

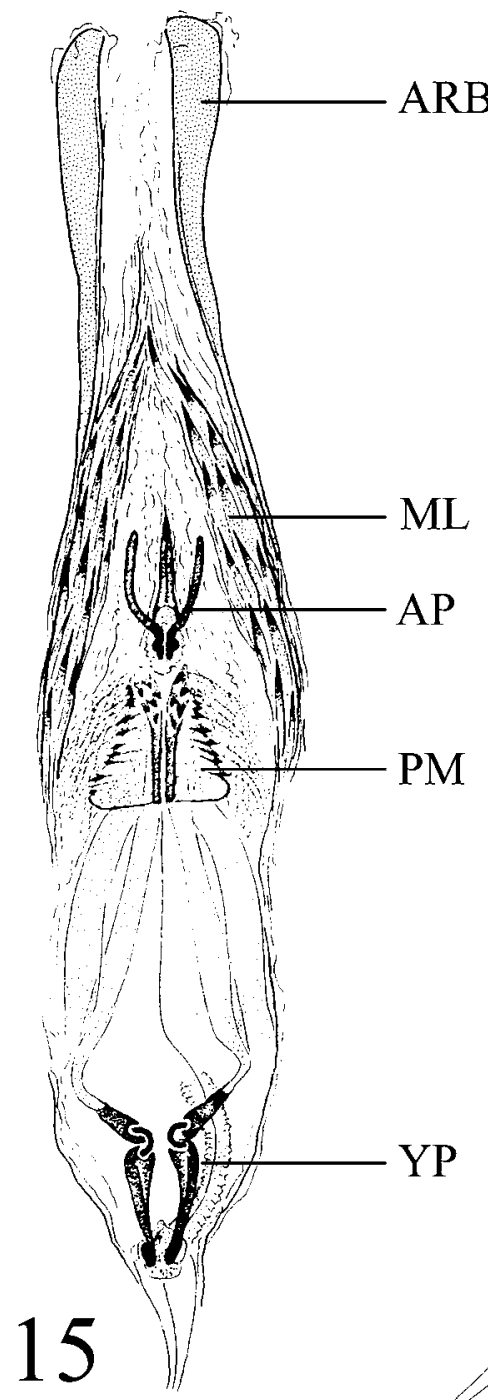

b
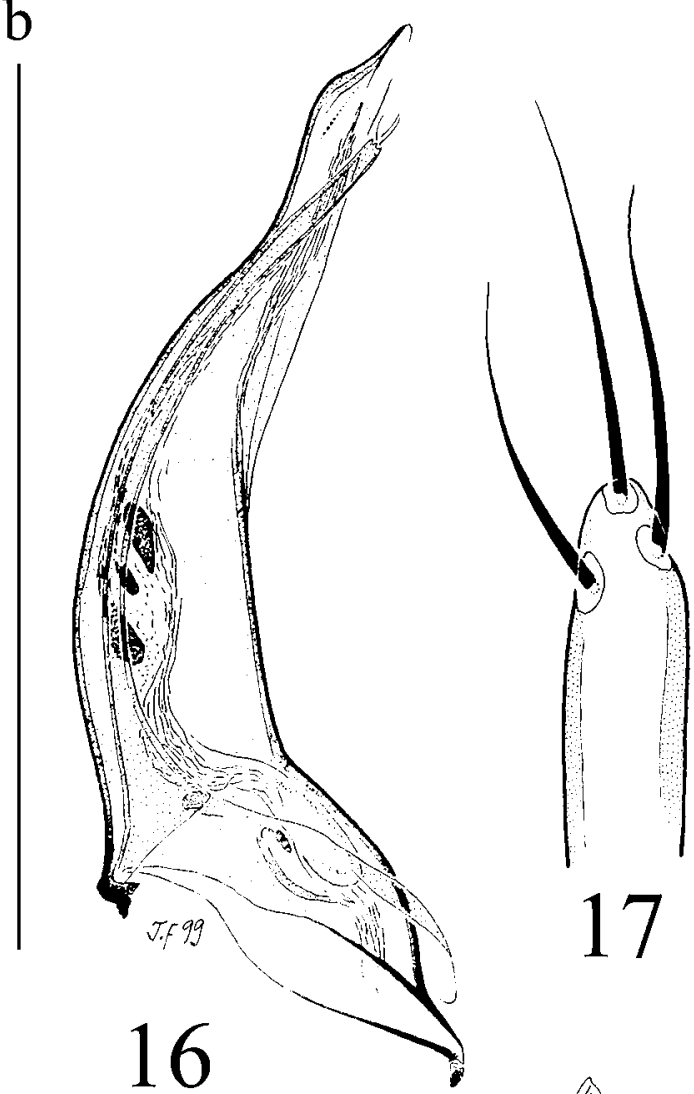
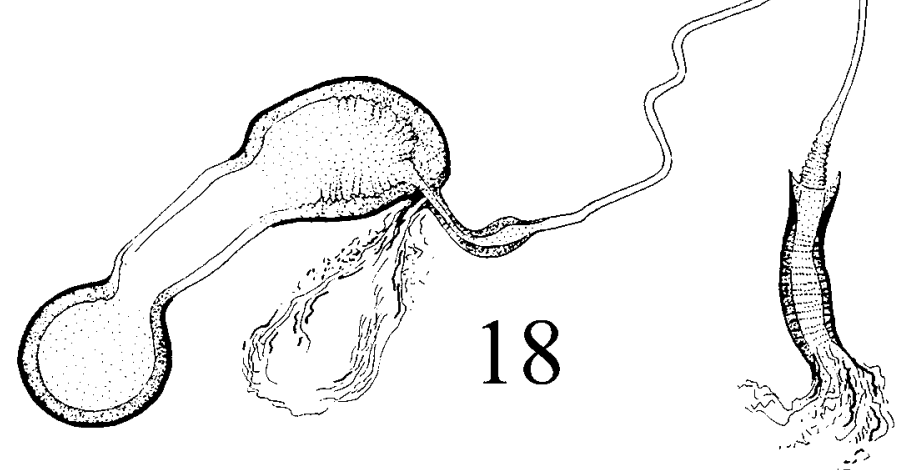

$\mathrm{C}$

Figs. 15-18.-Bathysciola (Bathysciola) ovata. 15) internal sac of the aedeagus in dorsal view. 16) aedeagus in lateral view. 17) apical region of the lateral style. 18) spermathecal complex. Scale bar: a-b, $0.5 \mathrm{~mm}: 15-16$; c, $0.1 \mathrm{~mm}$ : 18. AP, axial piece; ARB, apical reinforcement band; ML, membranous ligulae; PM, phanerae of the medial region; YP, Y-shaped piece.

Figs. 15-18.- Bathysciola (Bathysciola) ovata. 15) vista dorsal del saco interno del edeago. 16) vista lateral del edeago. 17) región apical del estilo lateral. 18) complejo espermatecal. Escala: a-b, $0.5 \mathrm{~mm}: 15-16$; c, $0.1 \mathrm{~mm}$ : 18. AP, pieza axial; ARB, banda de refuerzo apical; ML, lígula membranosa; PM, fanera de la región media; YP, pieza en forma de Y. 


\section{Bathysciola (Bathysciola) (zariquieyi group) zariquieyi serratensis Coiffait, 1959}

Bathysciola zariquieyi subsp. serratensis Coiffait, 1959. Ann. Spéléol., 14(1-2): 159

Bathysciola (Bathysciola) zariquieyi serratensis Coiffait: Perreau, 2000. Mém. de la SEF, 4: 229

MATERIAL STUDIED. The original description does not indicate how many specimens were studied, but there must have been several as the body size goes from " 1.5 to $1.7 \mathrm{~mm}$ " (Coiffait, 1959). Only one male specimen was examined stored in the Coiffait collection in MNHNP and labelled: 1. (hw Coiffait): Prov. Barcelona / Montserrat / St. Cécile 1 / 2.4.56. H Coiffait; 2. (hw Coiffait): subsp. / serratensis / Coiff.

COMPARATIVE STUDY. The type form is differentiated by its smaller size; also, the male protarsi with the first segment narrower than the distal extreme of the protibia in serratensis, of similar width in zariquieyi.

\section{Section VII of Jeannel, 1924 or ovata group of} Perreau, 2000

Bathysciola Sectio VII of Jeannel, 1924. Arch. Zool. exp. gén. 63(1): 113

Groupe ovata of Perreau, 2000. Mém. de la SEF, 4: 230

DiAgnosis. The Bathysciola in section VII are characterized by not having a parasutural stria, and the transverse striolae on the elytra. The internal sac of the aedeagus (Fig. 15) has an axial piece (Fig. 15: AP) and very small phanerae (Fig. 15: $\mathrm{PM}$ ) joined together in the median region, which may be triangular or practically forming a blunt nodule (Figs. 19, 22 and 25); the apical reinforcing bands (Fig. 15: ARB) rest on membranous ligulae (Fig. 15: ML) whose tegument may be covered in large spines. The internal sac of this group of species is very similar to that of Iberian species in the madoni group. Four species.

GeOgRAPHICAL Distribution. Both sides of the Pyrenees, French Massif Central and western foothills of the Alps, near Lyon (France).

\section{Bathysciola (Bathysciola) (ovata group) ovata ovata} (Kiesenwetter, 1850)

Bathyscia ovata Kiesenwetter, 1850. Stettiner entomol. Ztg., 11(7): 223

Adelops ovatus (Kiesenwetter): Miller, 1855. Verh. zool.botan. Ges. Wien, 5: 508

Bathyscia (Bathyscia) ovata Kiesw.: Reitter, 1885. Verh. naturforsch. Ver. Brünn, 23(1884): 34

Bathysciola ovata (Kiesenwetter): Jeannel, 1910. Arch. Zool. exp. gén., 45(1): 28

Bathysciola (Bathysciola) ovata (Kiesw.): Jeannel, 1914 Coleopterorum catalogus, pars 60: 10
Bathysciola (Bathysciola) ovata ovata (Kiesenwetter): Perreau, 2000. Mém. de la SEF, 4: 231

MATERIAL STUDiEd AND BIBLIOGRAPHICAL DATA. S-L, València d'Àneu, Mata de València, Español leg. (Español, 1956); S-L, Val d'Aran, VIII.1916, Zariquiey leg. (Bolívar, 1919); S-L, Vielha-Mijaran, Baricauba, Español leg. (Español, 1956); S-L, Bóssost, El Portilló, Español leg. (Español, 1956); S-L, Bóssost, 15.V.1916, Hilaire leg. (Bolívar, 1919); S-L, Baix Aran, Artiga de Lin, 18.IX.1954, HC leg., numerous specimens (Coiffait, 1959); S-L, Baix Aran, Artiga de Lin, 20.6.2001, JF leg., 6 exs.; 13.11.2002, JF leg., 4 ejs.; S-L, Baix Aran, Lés, (Español, 1956).

Male genitalia. In lateral view (Fig. 16) median lobe of aedeagus with basal two thirds rectilinear and base expanded; apical third folded in obtuse angle, strongly attenuated and sinuous; lateral style (Fig. 17) fine, sinuous and shorter than median lobe; bearing three long setae of similar length at tip, one of which possibly slightly shorter and finer; upper part of median region of internal sac of aedeagus (Fig. 15) with two sclerotized bands covered in long, fine spines; amongst them the shield of the axial piece is formed by two pieces joined together in a U-shape bearing a fine stylet in the middle; just below there are two triangular phanerae with an expanded interior margin also bearing a number of strongly robust spines.

Female Genitalia. Spermatheca (Fig. 18) short, rectilinear and robust; two differentiated spherical lobes joined by a cylindrical median region; spermathecal duct very short, as long as spermatheca; small nodule at insertion point and sclerotized tubular piece at point of contact with bursa copulatrix. Ovipositor corresponding to the model described for the phyletic series Speonomus (Fresneda, 1998); nevertheless, articulated distal piece not triangular but very fine with base slightly expanded at articulation point.

Discussion. The original description does not indicate the number of specimens studied and the specimen or the specimens of the type series have not been found in the investigations carried out in different museums. So, apart from the interpretation of the original description (Kiesenwetter, 1850 ), the characterisation of the species provided by different authors who state that they have identified the species (Bolívar, 1919; Jeannel 1911 \& 1924a; Español, 1956; Coiffait, 1959) has been accepted. Numerous specimens of French origin determined by R. Jeannel and H. Coiffat deposited in the M NHNP collection, have been located and studied. The original description indicates the type locality: "Bagnières de Luchon" (Kisenwetter, 
1850); different samplings carried out in the locality did not provide any specimens though some were found in a nearby locality; alter comparing them with the MNHNP specimens and verifying that it was the same species, they were used for the descriptions and illustrations in this study. A number of specimens from Artiga de Lin, Baix Aran, Lérida (Spain) were used for the description and illustrations. Bathysciola ovata belongs to section VII of the genus Bathysciola proposed by Jeannel (1924a). Considering the genital characters the relationship between $B$. ovata and the Iberian Bathysciola in section IV (B. madoni and B. penicillata) is quite evident: the internal sac of the aedeagus has a number of sacs with the tegument covered in spines, very short, triangular ventral phanerae and a robust sclerotized shield on the axial piece resembling a nodule situated in the upper part of the median region of the sac. The external morphology cannot be confused with other species and genera due to the peculiar facies: very small and apparently spherical. There is another character which is not found in the other specimens in the series of Iberian Speonomus or in the other three species in the group: the mesosternal carina is prolonged over the metasternum in a similar way to most of the specimens in the series Quaestus (supraflagellates). Five subspecies which are difficult to place were described. One of them (Bathysciola ovata minuscula Abeille de Perrin, 1901) has been considered in the section incertae sedis as the single specimen of the type series is a female and its identity and relationship have not been determined. The complex is distributed on both sides of the Pyrenees.

\section{Bathysciola (Bathysciola) (ovata group) ovata aragonica Coiffait, 1959}

Bathysciola ovata subsp. aragonica Coiffait, 1959. Ann. Spéléol., 14(1-2): 164

Bathysciola (Bathysciola) ovata aragonica Coiffait: Perreau, 2000. Mém. de la SEF, 4: 230

Material STUDied. The original description does not indicate how many specimens were studied. "Type: Espagne, Province de Lérida, Bono, dans la vallée de la Noguera Ribagorzana (ma collection)" (Coiffait, 1959). Only one specimen of the type series has been located preserved in the Coiffait collection at the MNHNP. It is labelled: 1. (hw Coiffait): Prov. Lerida / Bono / 1-XI-55. H. Coiff. The following material was studied: S-HU, Bonansa, Borda Ansuilo, 6.V.1998, JF leg., 3 males and 3 females preserved in col. JF; S-HU, Bonansa, Cova de Sant Salvador de Bibils, 14.XI.2004, JF leg., 17 exs., in col. JF and col. Ribera; 20.XI.2004, JF leg., 20 exs., in col. JF.
COMPARATIVE STUDY. The male genitalia is identical to that of the nominotypic subspecies. It is distinguished from B. o. ovata by the elytral sculpture, considerably more visible and rugose in aragonica.

\section{Bathysciola (Bathysciola) (ovata group) ovata catalana Coiffait, 1959}

Bathysciola ovata subsp. catalana Coiffait, 1959. Ann. Spéléol., 14(1-2): 164

Bathysciola (Bathysciola) ovata catalana Coiffait: Perreau, 2000. Mém. de la SEF, 4: 230

Material StUdied. Coiffait (1959) studied a series of specimens indicating: "Type: Espagne, Province de Gérone, Ripoll. Une série d'exemplaires des deux sexes...". The material belonging to the type series, suitably labelled and preserved at the MNHNP has been studied; two of the specimens have holotype and paratype labels: one specimen: 1. (hw Coiffait): Prov. Gerona Ripoll / 28.12.55 H. Coiffait; 2. (hw Coiffait): HOLOTYPE; One specimen: 1. (hw Coiffait): Prov. Gerona Ripoll / 28.12.55 H. Coiffait; 2. (hw Coiffait): PARATYPE. There are 21 more specimens: 1. (hw Coiffait): Prov. Gerona Ripoll / 28.12.55 H. Coiffait.

COMPARATIVE STUDY. The male genitalia is identical to that of $B$. o. ovata. It is differentiated from the nominotypic subspecies by the lower and even more obtuse mesosternal carina.

\section{Bathysciola (Bathysciola) (ovata group) ovata gabasensis Hustache, 1913}

Bathysciola ovata var. gabasensis Hustache 1913. Bull. Soc. entomol. Fr., 18: 86

Bathysciola (Bathysciola) ovata subsp. gabasensis Hustache: Jeannel, 1914. Coleopterorum catalogus pars 60: 10

Bathysciola ovata subsp. gabasensis Hustache: Fagniez, 1927. Misc. entomol., 30 (1926) (3): 20

Bathysciola (Bathysciola) ovata gabasensis Hustache: Perreau, 2000. Mém. de la SEF, 4: 231

MATERIAL STUDIED. Bathysciola ovata gabasensis was described as a variety from the Ossau valley (Gabas) and later recorded in other localities in the department of the Pyrénées Atlantiques in France. In the original description no indication was made of the number of specimens in the type series, though Hustache (1913) clearly states having studied several specimens: "j'ai capturé en nombre Bathysciola ovata Kiesw.,...", "ils constituent une race spéciale à cette region, pour laquelle je propose le nom de var. gabasensis, n. var.". In the MNHNP general collection three ejemplares of the type series were found inserted in the same pin and separated. They are: 1 (hw): Gabas; 2 (i, red letters): TYPE; 3 (i): MUSEUM PARIS / Coll. R. JEANNEL 1931. Two specimens male and female identified with a copy of the original labels, identical to those of the other specimen. Also, other specimens in the same collection have been studied: F-B. Pyr., Grotte de Malarade, VIII.1913, RJ leg., 2 males and 2 females. 
COMPARATIVE STUDY. The male genitalia is identical to B. o. ovata. B. o. gabasensis is characterised by its high mesosternal carina which form a right or somewhat acute angle; whereas the carina in $B . o$. ovata is lower and clearly obtuse.

\section{Bathysciola (Bathysciola) (ovata group) asperula asperula (Fairmaire, 1857)}

Adelops asperulus Fairmaire, 1857. Ann. Soc. ent. Fr., 26: 731 Bathyscia (Bathyscia) asperula (Fairm.): Reitter, 1885. Verh. naturforsch. Ver. Brünn, 23(1884): 34

Bathysciola asperula (Fairmaire): Jeannel, 1910. Arch. Zool. exp. gén., 45(1): 28

Bathysciola (Bathysciola) asperula (Fairm.): Jeannel, 1914 Coleopterorum catalogus pars 60: 7

Bathysciola (Bathysciola) asperula subsp. asperula (Fairmaire, 1857): Jeannel, 1924. Arch. Zool. exp. gén., 63(1): 114

Bathysciola (Bathysciola) asperula asperula (Fairmaire): Perreau, 2000. Mém. de la SEF, 4: 230

MATERIAL STUDIED. In the original description the author studied "quelques individus" (Fairmaire, 1857). A male specimen belonging to the type series was found, deposited in the general MNHNP collection and labelled: 1. (hw): 6231; 2. (hw): A. aspirn / leg Fairm; 3. (i): TYPE; 4. (i): MUSÉUM PARIS / Collection Léon / Fairmaire 1906; 5. (hw): Adelops / asperulus F.

Male Genitalia. Median lobe of aedeagus (Fig. 20) slender, basal region rectilinear in lateral view, whereas the rest is smooth and uniformly arcuate to pointed tip; lateral style almost as long as median lobe; fine, arcuate, with distal area strongly folded towards median lobe; three subequal setae inserted in distal extreme (Fig. 21); internal sac of aedeagus (Fig. 19) with few delicately sclerotized pieces; Y-shape in basal region with very fine arms; median region exhibiting small elongate bifurcate nodule in axial position; very long reinforcing bands in apical region.

Discussion. A series of specimens from the Grotte de l'Herm, Ariége (France) was used in the description. These specimens are identical to the specimen of the type series found in the col. MNHNP. The male genitalia of Bathysciola asperula is different to that of $B$. ovata, including the median lobe and in particular, the internal sac. It is similar to B. simonis and related to B. talpa. The most similar species is $B$. simonis. The internal sacs of the aedagus of these two taxa are similar but the median lobe is shaped differently: it is uniformly curved in B. simonis, the basal portion being much more robust, whereas the basal portion in $B$. asperula is rectilinear and elongate. Also, the lateral styles -in lateral view- are fine and slender in $B$. asperula and more robust in B. simonis. As for $B$. talpa: lateral style fine to tip and the distal tip of the fine, weakly curved median lobe in B. asperula are very different to the thick lateral style ending in a club and the thick strongly curved tip of the median lobe in B. talpa; in any case although the relationship between these taxa must be distant, their genitalia have a vaguely similar facies. $B$. asperula is distributed in the French departments of Ariége and Aude on the northern slope of the Pyrenees.

\section{Bathysciola (Bathysciola) (ovata group) asperula subasperata (Saulcy, 1872)}

Adelops subasperatus Saulcy, 1872. In Abeille de Perrin, Synopsis des Adelops Pyrénéens: 22

Bathyscia (Bathyscia) meridionalis Duv.: Reitter, 1885. Verh. naturforsch. Ver. Brünn, 23(1884): 33

Bathyscia schioedtei subsp. subasperata (Saulcy): Jeannel, 1907. Ann. Soc. entomol. Fr., 76: 423

Bathyscia asperula subsp. intermedia Jeannel, 1909. Bull. Soc. entomol. Fr., 14: 19

Bathysciola schiodtei subsp. subasperata (Saulcy): Jeannel, 1911. Arch. Zool. exp. gén., 47(1): 248

Bathysciola (Bathysciola) schiodtei subsp. subasperata (Saulcy): Jeannel, 1914. Coleopterorum catalogus pars 60: 10 Bathysciola (Bathysciola) asperula subasperata (Saulcy): Perreau, 2000. Mém. de la SEF, 4: 230

MATERIAL STUDied. Lectotype male labelled: 1. (hw): Ornolac; 2. (hw): male; 3. (hw, in red): Collect de Saulcy; 4. (i, in red): Type; 5. (hw, in red): Type; 6. (hw): subasperatus; 7. (hw): Bathysciola subasperata Saulcy; 8. (i): Muséum Paris, Coll. F. P. de Saulcy, Coll. A. Argod. 1931; 9. (i, hw, in red): Lectotype male, B. Secq dés. 1994; 10. (hw): Bathysciola asperula subasperata $($ Saulcy) $=$ intermedia Jeannel, B. Secq dét. 1994. In the original description of Bathyscia asperula intermedia (Jeannel, 1909) the number of studied specimens was not given. Lectotype male labelled: 1. (hw): Mt Estelas; 2. (i, in red): Type; 3. (i): Muséum Paris, Coll. R. Jeannel. 1931; 4. (hw, in red): intermedia, Type; 5. (i, hw, in red): Lectotype male, B. Secq dés. 1994; 6. (hw): Bathysciola asperula subasperata $($ Saulcy $)=$ intermedia Jeannel, B. Secq dét. 1994.

COMPARATIVE STUDY. The male genitalia is identical to that of the nominotypic subspecies; they are basically differentiated from the latter by being slightly larger. Secq \& Secq (1996) established the synonym $B$. asperula intermedia with $B$. asperula subasperata. The lectotype and paralectotypes of these taxa were designated in the same study. In the original description of Adelops subasperatus (Saulcy, 1872) the number of studied specimens was not specified.

\section{Bathysciola (Bathysciola) (ovata group) simonis} (Abeille de Perrin, 1875)

Adelops simonis Abeille de Perrin, 1875. Ann. Soc. entomol. Fr. (Bull. séances), 44: 199 

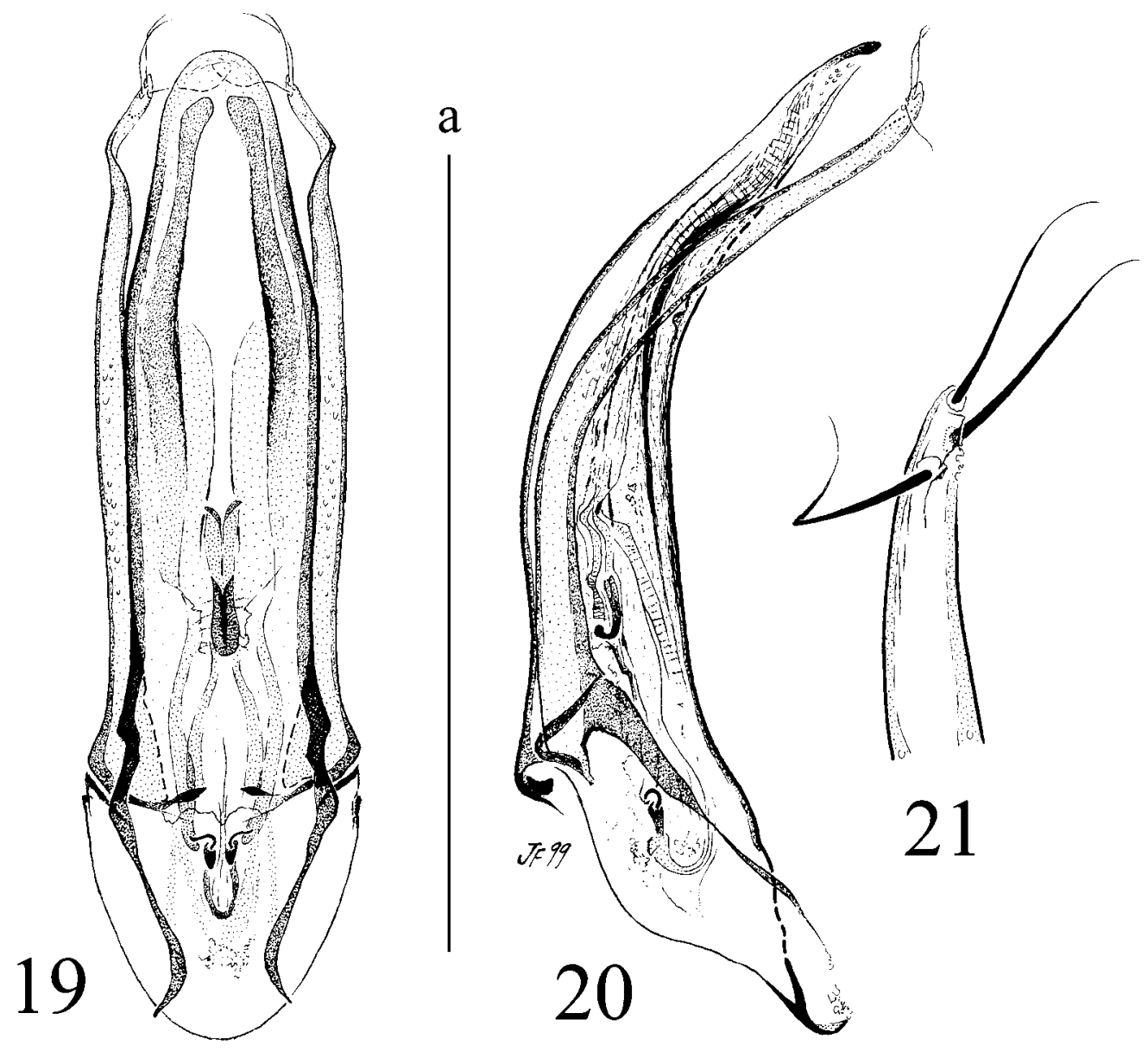

Figs. 19-21.-Bathysciola (Bathysciola) asperula. 19) aedeagus and internal sac in dorsal view. 20) aedeagus in lateral view. 21) apical region of the lateral style. Scale bar: a, $0.5 \mathrm{~mm}: 19,20$.

Figs. 19-21.- Bathysciola (Bathysciola) asperula. 19) edeago y vista dorsal del saco interno. 20) vista lateral del edeago. 21) región apical del estilo lateral style. Escala: a, $0.5 \mathrm{~mm}:$ 19, 20.

Bathyscia (Bathyscia) simonis (Abeille): Reitter, 1885. Verh natursforsch. Ver. Brünn, 23(1884): 34

Bathysciola asperula subsp. simoni (Abeille): Jeannel, 1910. Arch. Zool. exp. gén., 45(1): 28

Bathysciola (Bathysciola) asperula subsp. simoni (Abeille de Perrin): Jeannel, 1914. Coleopterorum catalogus pars 60: 7 Bathysciola (Bathysciola) asperula simonis (Abeille de Perrin): Perreau, 2000. Mém. de la SEF, 4: 230

MATERIAL STUDIED. In the original description of $B$. simonis the number of studied specimens is not indicated: "Découvert par M. Eugène Simon dans des mousses, au Lioran (Cantal)" (Abeille de Perrin, 1875). The specimens of the type series were not found. The following specimens from the MNHNP general collection were studied: F-Tarn et Garonne, Lacaune, alt. 850 m., Galibert leg., 4 males and 5 females; F, Le Lioran, 28.10.1892, Grouvelle leg., 1 female; F, Le Lioran, Falcoz leg., 1 male; F, Aveyron, La Cavalerie, 17.7.1925, 1 female.
MALE GENITALiA. Median lobe of aedeagus slender (Fig. 23) and uniformly curved from base to apical third; in lateral view, from this point sinuous, pointed tip slightly expanded and curved; lateral style almost as long as median lobe; robust, arcuate with distal region strongly folded towards median lobe; bearing three subequal setae inserted in distal extreme (Fig. 24); internal sac of aedeagus (Fig. 22) with few weakly sclerotized pieces; Yshaped piece in basal region with fine arms; median region with two elongate nodules touching on the axial line of the sac, set out on a triangular piece and covered in striate tissue; reinforcing bands without any outstanding characters. 

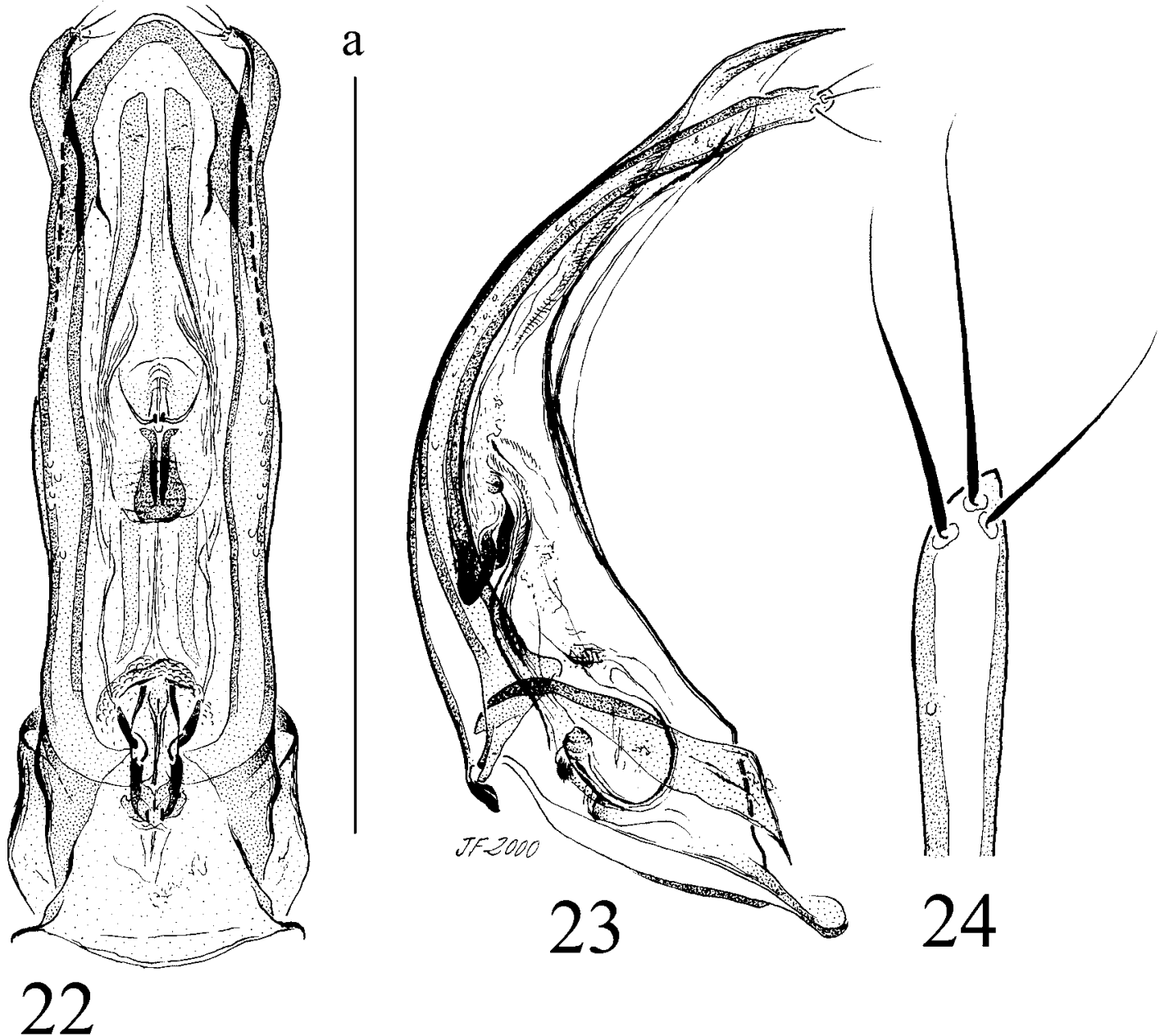

Figs. 22-24.-Bathysciola (Bathysciola) simonis. 22) aedeagus and internal sac in dorsal view. 23) aedeagus in lateral view. 24) apical region of the lateral style. Scale bar: a, $0.5 \mathrm{~mm}: 22,23$.

Figs. 22-24.- Bathysciola (Bathysciola) simonis. 22) edeago y vista dorsal del saco interno. 23) vista lateral del edeago. 24) región apical del estilo lateral. Escala: a, $0.5 \mathrm{~mm}: 22,23$.

Discussion. A series of specimens from Lacaune in the department of Tarn (France) were used for the description and illustrations. The most similar species is $B$. asperula, which is clearly related. The internal sacs of the aedeagus of these taxa are very similar but the shape of the median lobe is quite different: rectilinear and elongate in $B$. asperula and uniformly arcuate in $B$. simonis, in the latter species the basal portion is much more robust. The lateral styles, in lateral view, are more robust in $B$. simonis than in the other species. This taxon was described as a species but considered by Jeannel (1910) as a subspecies of $B$. asperula.

\section{Bathysciola (Bathysciola) (ovata group) talpa}

(Normand, 1907)

Bathyscia talpa Normand, 1907. Bull. Soc. entomol. Fr., 12: 121

Bathyscia asperula ssp. talpa Normand: Jeannel, 1909. Bull. Soc. entomol. Fr., 14: 19

Bathysciola asperula ssp. talpa (Normand): Jeannel, 1910. Arch. Zool. exp. gén., 45 (1): 28

Bathysciola (Bathysciola) asperula subsp. talpa (Normand): Jeannel, 1914. Coleopterorum catalogus pars 60: 7

Bathysciola talpa (Normand): Coiffait, 1959. Ann. Spéléol., 14 (1-2): 164

Bathysciola (Bathysciola) talpa (Normand): Perreau, 2000. Mém. de la SEF, 4: 231 


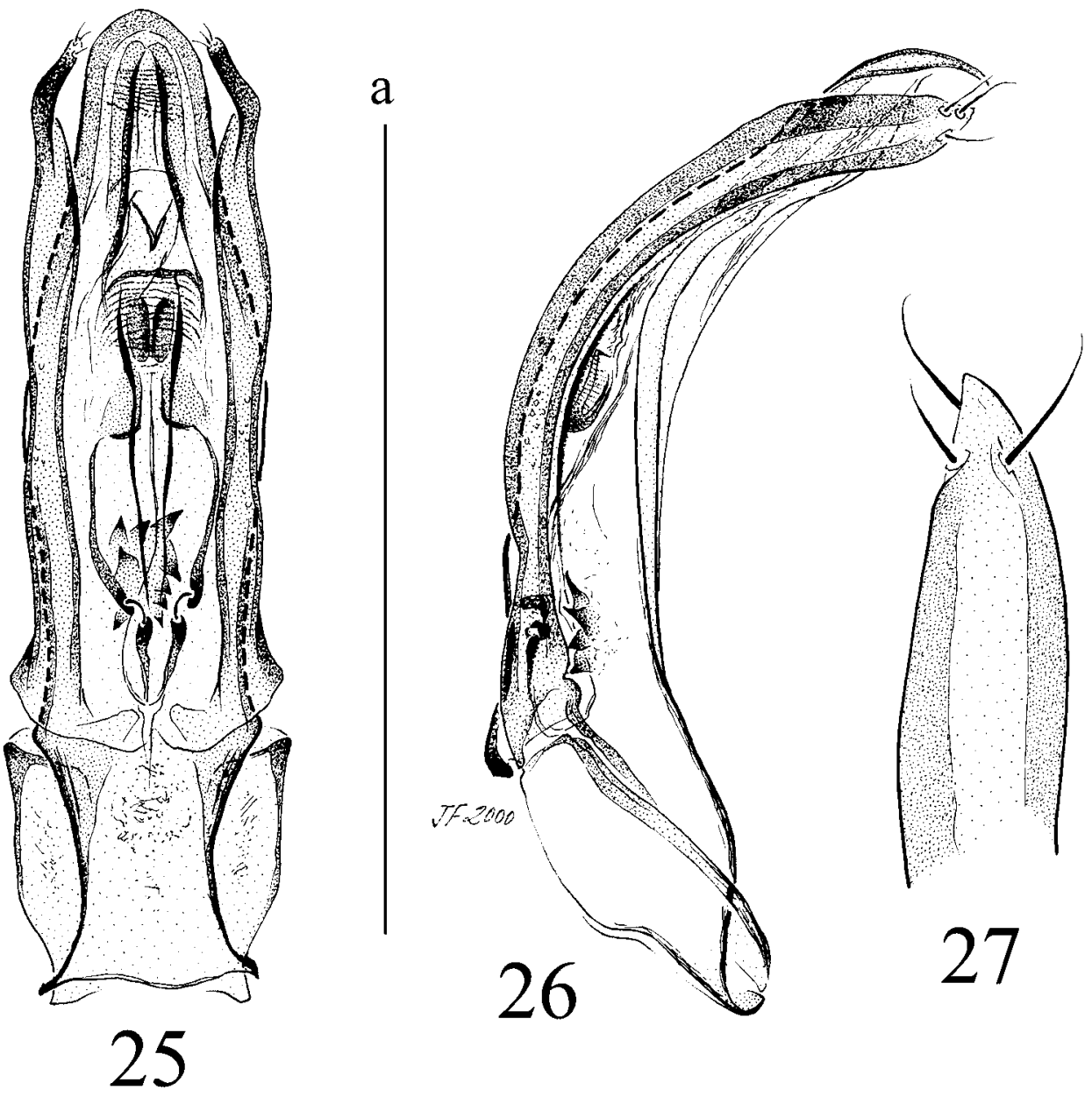

Figs. 25-27.-Bathysciola (Bathysciola) talpa. 25) aedeagus and internal sac in dorsal view. 26) aedeagus in lateral view. 27) apical region of the lateral style. Scale bar: a, $0.5 \mathrm{~mm}: 25,26$.

Figs. 25-27.- Bathysciola (Bathysciola) talpa. 25) edeago y vista dorsal del saco interno. 26) vista lateral del edeago. 27) región apical del estilo lateral. Escala: a, $0.5 \mathrm{~mm}: 25,26$.

MATERIAL STUDIED. The original description does not specifiy the number of specimens in the type series, though Normand (1907) studied both sexes. One of the species mentioned in the original description has been located in the MNHNP general collection and is labeled as follows: 1 (hw): Serres Foix / Dr. Normand; 2 (i): MUSEUM PARIS / Coll. R. JEANNEL 1931; 3 (hw): talpa. Also, the following specimens from the same collection have been from the same collection have been studied: F-Ar., Grotte de Ferolac, RJ leg., 1 female; F-Ar., Massat, 1 female.

Male genitalia. Median lobe of aedeagus (Fig. 26) slender, basal region rectilinear in lateral view, rest curved to terminal third where it becomes strongly sinuous; tip expanded and strongly curved; lateral style almost as long as median lobe, very thick and arcuate, distal region strongly expanded and club-shaped bearing three short subequal setae (Fig. 27); a small number of weakly sclerotized pieces in the internal sac of the aedeagus (Fig. 25); Yshaped piece in basal region with short fine arms; inferior area of the median region with six thick spines, and upper part two small elongate nodules, touching, set out on a lamina; reinforcing bands of the apical region with no outstanding characters.

Discussion. A specimen from Foix in the department of Ariège (France) was used for the description and illustrations. The internal sac of the aedeagus clearly resembles to $B$. asperula; howe- 
ver, differences in the genitalia of the two taxa are enormous: the very thick lateral style ending in a club and the thick strongly curved tip of the median lobe in $B$. talpa contrasts heavily with the lateral style which are fine to the tip, and distal tip of the fine, weakly curved median lobe in $B$. asperula. The six strong spines in the median region of the internal sac of $B$. talpa are found exclusively in this species. The first segment of the male protarsi in $B$. talpa is also remarkable: it is much wider than the distal extreme of the protibia and heart-shaped. There is no similar case amongst the Leptodirinae in this study in which the first segment is always equal, slightly wider or narrower than the protibia. This species was considered a subspecies of $B$. asperula by Jeannel (1910) and bona species by Coiffait (1959); Normand (1907) posed the possibility of describing it as a subspecies subordinate to B. asperula.

\section{Section VI of Jeannel, 1924}

Bathysciola Sectio VI of Jeannel, 1924. Arch. Zool. exp. gén., 63(1): 169

Elytra lacking sutural stria, but with transverse striolae; the tip of the lateral style of the aedeagus is armed with four setae.

\section{The lapidicola new group}

DiAgnosis. The male genitalia of Bathysciola lapidicola (Saulcy, 1872) is taken as the model. A series of specimens from Aubert, Ariège (France) were used for the description and illustrations. This group is characterised by the more or less slender aedeagus in lateral view (Figs. 29 and 32), and folded in an obtuse angle in the mid region; there may be an expanded ventral area in the upper part of the basal region; in dorsal view it is robust, with almost parallel sides, weakly converging to the slightly truncate tip; lateral style somewhat shorter than median lobe and four tiny setae in line transversally inserted in tip (Figs. 30 and 33); internal sac of aedeagus (Figs. 28 and 31) characterized by two elongate, triangular shaped phaneroid complexes (Fig. 31: PCM), situated on either side of the symmetry axis of the sac, in the median region; the apical reinforcing bands (Fig. 31: ARB) rest upon membranous ligulae (Fig. 31: ML). This complex is related to the Bathysciola of the meridionalis group because of certain similarities in the internal sac of the aedagus: it is as though the basal pieces of the two longitudinal phaneroid complexes of the lapi- dicola group were joined by their internal margin in the same way as the phanerae in the meridionalis group, and forming a U-shape or almost a ring formed by several pieces. There is no similarity with other models of internal sac. In any case the differences between the internal sac of lapidicola and the meridionalis group are considerable and affect the number, shape and position of the sclerotized shield. Two species.

GEOGRAPHICAL DISTRIBUTION. The group is distributed throughout low altitude mountainous regions in the French departments of Haute Garonne and Ariège, on the northern slope of the Pyrenees.

\section{Bathysciola (Bathysciola) (lapidicola group) arcuatipes Jeannel, 1924}

Bathysciola (Bathysciola) arcuatipes Jeannel, 1924. Arch. Zool. exp. gén., 63(1): 112

Material StUdied. Jeannel (1924a) does not indicate the number of specimens in the type series. "Type: grotte d'Aubert (coll. A. Dodero)". Six specimens in the type series have been located in the MNHNP. First specimen: 1. (hw): grotte / d'Aubert; 2.: (i) R. Jeannel / (hw) Ar. VIII-26; 3. (i): TYPE; 4. (i): MUSÉUM PARIS / Coll. R. Jeannel 1931. There are another four specimens labelled but without the «TYPE" label, in the MNHNP general collection. Finally, one last specimen is included in the description of the species: Cazavet / 21.IV.1914 / Dodero. It should be pointed out that whilst the description of the taxon is dated 1924, the type series -as indicated by the label handwritten by Jeannelwas collected in 1926 by Jeannel himself; however, there is no doubt about its identity as one of the specimens had the "TYPE" red label. R. Jeannel may have made a mistake when labelling or the number corresponding to 1924 of the Arch. Zool. exp. gén. may have been published late. The following specimens are also found in the MNHNP general collection: F-Ar., Aubert, Grotte d'Aubert, Argod leg., 2 exs. Also in the MNHNP, but in the Coiffait collection are: F-Ar., Aubert, Grotte d'Aubert, 18.6.1943, HC leg., 3 exs.; 28.9.1945, HC leg., 2 exs.; F-Ar., Foret de Lestelas, VII.1958, HC leg., 1 ex.

Male Genitalia. Aedeagus in lateral view (Fig. 29) uniformly curved and robust, especially the basal portion, without expanded ventral area in the median region; tip prolonged and very pointed. Lateral style tip with four tiny setae transversally set out in a line (Fig. 30). Internal sac of aedeagus (Fig. 28) characterised by two elongate triangularshaped phaneroid complexes, situated on both sides of the symmetry axis, in median region; upper area of these pieces prolonged in bundles of weakly defined twisted fibres in the upper parts of the internal sac; the two lateral phanerae of tip of basal 


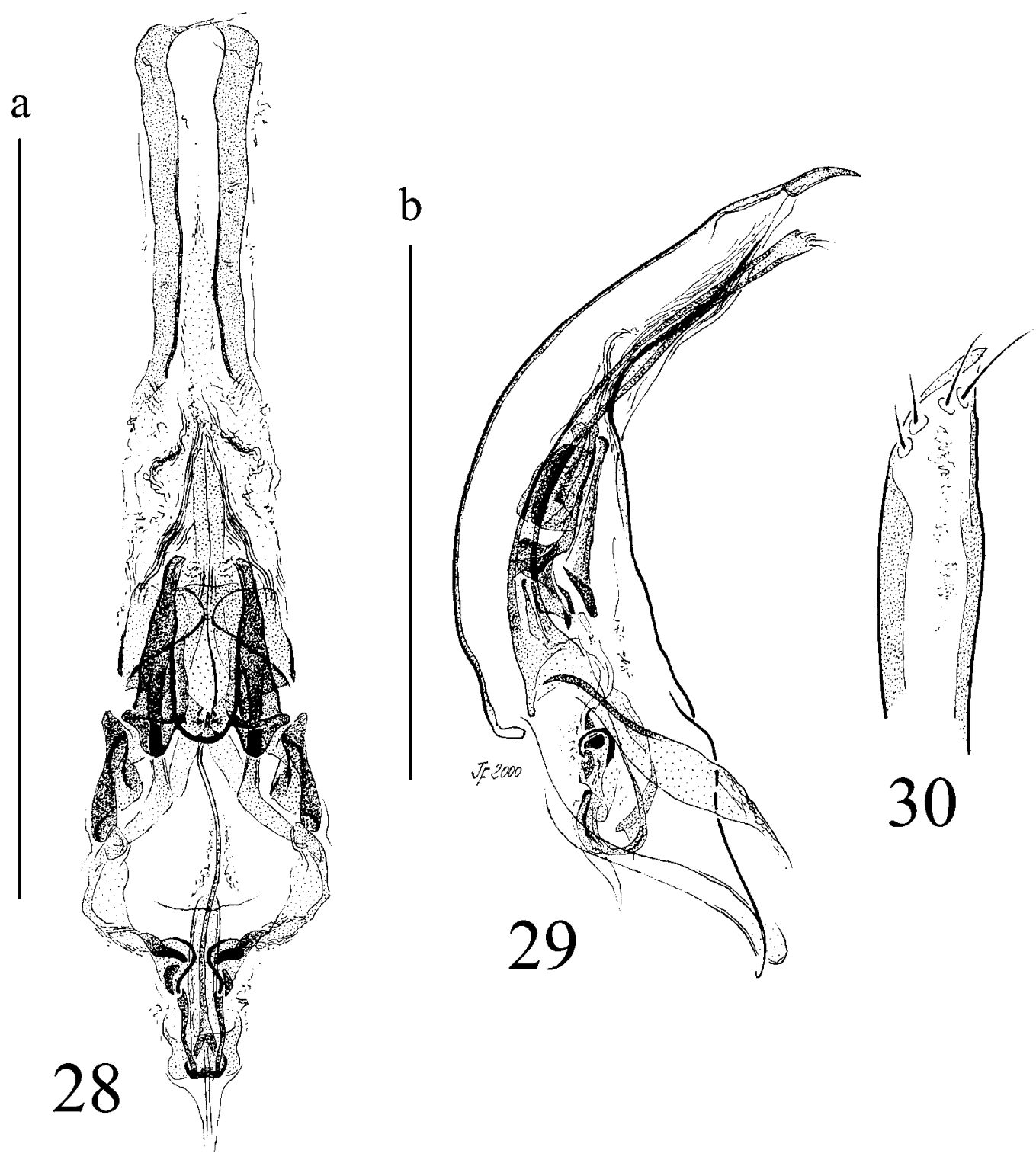

Figs. 28-30.-Bathysciola (Bathysciola) arcuatipes. 28) internal sac of the aedeagus in dorsal view. 29) aedeagus in lateral view. 30) apical region of the lateral style. Scale bar: a-b, $0.5 \mathrm{~mm}: 28,29$.

Figs. 28-30.- Bathysciola (Bathysciola) arcuatipes. 28) vista dorsal del saco interno del edeago. 29) vista lateral del edeago. 30) región apical del estilo lateral. Escala: a-b, $0.5 \mathrm{~mm}: 28,29$.

region (floating pieces of other models of internal sac, Fresneda, 1998) large and noticeably sclerotized to upper extreme.

Discussion. The possibility of transferring $B$. arcuatipes to the $B$. lapidicola complex as another subspecies has been discussed. However, not enough specimens have been studied, particularly those in the subspecies B. lapidicola; they are only known from the type localities and only the specimens in the type series, normally one or two specimens. The existing specific and subspecific table is to be provisionally maintained until a good representation of all the taxa is obtained. This species is 
closely related to B. lapidicola simplex, as they have similar male metatibiae: triangular and slightly curved in the apical fourth. The basal region of the aedeagus of $B$. arcuatipes (Fig. 29) is more robust and does not have a ventrally expanded area which is characteristic of $B$. lapidicola (Fig. 32); their respective internal sacs of the aedeagus are very similar and it is difficult to define small differences between B. arcuatipes (Fig. 28) and B. lapidicola (Fig. 31).

\section{Bathysciola (Bathysciola) (lapidicola group) lapidicola lapidicola (Saulcy, 1872)}

Adelops lapidicola Saulcy, 1872. In Abeille de Perrin: Synopsis des Adelops Pyrénéens: 22

Bathyscia (Bathyscia) lapidicola (Saulcy): Reitter, 1885. Verh. naturforsch. Ver. Brünn, 23(1884): 33

Bathysciola lapidicola (Saulcy): Jeannel, 1910. Arch. Zool. exp. gén., 45(1): 29

Bathysciola (Bathysciola) lapidicola (Saulcy): Jeannel, 1914. Coleopterorum catalogus pars 60: 9

Bathysciola (Bathysciola) lapidicola lapidicola (Saulcy): Perreau, 2000. Mém. de la SEF, 4: 236

Material STUDIED. The number of specimens studied is not indicated in the original description. The following specimens belonging to the type series were found preserved in the MNHNP general collection. Two specimens in the same pin labelled: 1. (hw): Aubert pierres / Abeille; 2. (i): Collect / de Saulcy; 3 (i, in red): TYPE; 4. (hw): lapidicola / type; 5. (i): MUSÉUM PARIS / Coll F. P. de Saulcy / Coll A. ARGOD. 1931. Two specimens preserved in the MNHNP general collection and labelled: first specimen: 1. (hw): Aubert pierres $/$ Abeille; 2. (hw): lapidicola; 3. (i): Collect. de Saulcy; 4. (i, in red): COTYPE; 5. MUSÉUM PARIS / Coll F. P. de Saulcy / Coll A. ARGOD. 1931. Second specimen: 1. (hw): Aubert pierres / Abeille; 2. (hw): lapidicola / type; 3. (i): Collect. de Saulcy; 4. (i, in red): COTYPE; 5. MUSÉUM PARIS / Coll F P. de Saulcy / Coll A. ARGOD. 1932. Jeannel (1924a) indicates that the type series is from Grotte de Lestelas; but the located specimens are labelled as being from Aubert, where they must have been found under stones.

Male Genitalia. In lateral view (Fig. 32) aedeagus slender and folded in obtuse angle in the middle more or less; ventrally expanded area in upper part of basal region; in dorsal view, robust, with almost paralell sides, weakly converging in slightly truncate tip; lateral style somewhat shorter than median lobe, four tiny setae transversally set out inserted in tip (Fig. 33); internal sac of aedeagus (Fig. 31) characterised by two elongate, triangular phaneroid complexes on either side of the axis of symmetry of the sac, in median region; the upper part of these pieces is prolonged in a kind of well-defined translucid phanera in the upper part of the internal sac; the two lateral phanerae of the tip of the basal region (floating pieces of other models of internal sac, Fresneda, 1998) are small, upper extreme weakly sclerotised.

Discussion. Specimens in the type series from Aubert, Ariége (France) were used to illustrate the male genitalia. Bathysciola lapidicola is closely related to $B$. arcuatipes: see discussion on $B$. arcuatipes. Bathysciola lapidicola is a complex of four subspecies based on inconsistent characters. In the subspecies described, there is some variation in the shape of the median lobe of the aedeagus and the internal sac; there are also some insignificant differences in secondary sexual characters, such as the shape of the male metatibiae. Two of the subspecies have been described based on a very small number of specimens-one and two specimens, respectivelyand the differential characters have such little significance that the option of establishing the synonymy with the nominotypic subspecies has been considered; it was decided to preserve them provisionally until new specimens were collected: if the differential characters, though small, exist in all the population and if the population has a determined distribution area, the category of subspecies would be justified.

\section{Bathysciola (Bathysciola) (lapidicola group) lapidicola rectipes Coiffait, 1959}

Bathysciola lapidicola subsp. rectipes Coiffait, 1959. Ann. Spéléol., 14(1-2): 162

Bathysciola (Bathysciola) lapidicola rectipes Coiffait: Perreau, 2000. Mém. de la SEF, 4: 236

Material studied. Coiffait (1959) studied a small series of specimens. "Type: Grotte de Gouillou à Izaut de l'Hôtel, Haute-Garonne, une petite série..."; three have been located. The type series is in the Coiffait collection at the MNHNP and the specimens are labelled as follows one specimen: 1. (hw Coiffait): H. Gar. Izaut / Gr de Gouillou / V-55. H. Coiffait; 2. (hw Coiffait): ssp rectipes / Coiff.; 3. (hw Coiffait, in red): HOLOTYPE. Two specimens: 1. (hw Coiffait): H. Gar. Izaut / Gr de Gouillou / V-55. H. Coiffait; 2. (hw Coiffait): ssp rectipes / Coiff.; 3. (hw Coiffait, in red): PARATYPE. The following specimens in the Coiffait collection in MNHNP were also studied: F-H. Gar., Aspet, Grotte de Peyreblanche, 1.IX.1954, HC leg., 2 exs.; F-H. Gar., Izaut de l'Hotel, entrée de la Grotte de Gouillou, IV.1960, HC leg., 3 exs.

COMPARATIVE STUDY. In lateral view aedeagus tends to be slightly more robust than type form but with ventrally expanded area in upper extreme of basal region. It is differentiated from lapidicola by the straight, slender metatibiae, expanded from the first third and then subparallel to the tip. 


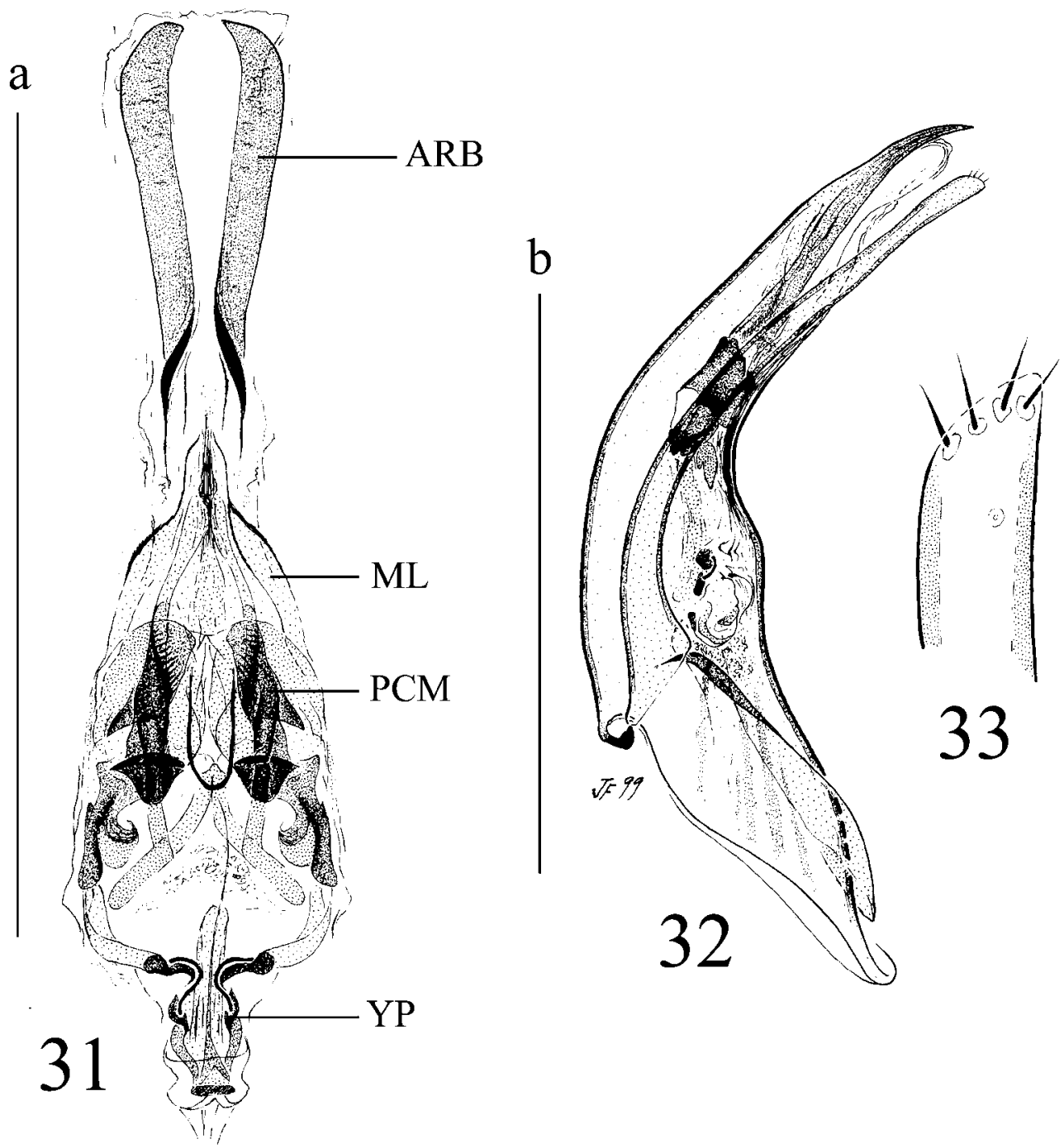

Figs. 31-33.- Bathysciola (Bathysciola) lapidicola. 31) internal sac of the aedeagus in dorsal view. 32) aedeagus in lateral view. 33) apical region of the lateral style. Scale bar: a-b, $0.5 \mathrm{~mm}: 31,32$. ARB, apical reinforcement band; ML, membranous ligulae; PCM, phanerae complex of the medial region; YP, Y-shaped piece.

Figs. 31-33.- Bathysciola (Bathysciola) lapidicola. 31) vista dorsal del saco interno del edeago. 32) vista lateral del edeago. 33) región apical del estilo lateral. Escala: a-b, $0.5 \mathrm{~mm}: 31$, 32. ARB, banda de refuerzo apical; ML, lígula membranosa; PCM, complejo de faneras de la región media; YP, pieza en forma de Y.

\section{Bathysciola (Bathysciola) (lapidicola group) lapidicola simplex Coiffait, 1959}

Bathysciola lapidicola subsp. simplex Coiffait, 1959. Ann. Spéléol., 14(1-2): 161

Bathysciola (Bathysciola) lapidicola simplex Coiffait: Perreau, 2000. Mém. de la SEF, 4: 236

Material STUdiED. The number of specimens in the type series is not indicated and a male specimen is described. "Type:
Gouffre Djerbao vers $1.100 \mathrm{~m}$ à Arbas, Haute-Garonne (M. Bouillon). Ma collection." (Coiffait, 1959). This specimen is preserved in the col. Coiffait in MNHNP and labelled: 1. (hw Coiffait): H. Gar. Arbas / Gouffre de Djerbao / 8-56. M.B.; 2. (hw Coiffait): ssp. simplex / Coiff.; 3. (hw Coiffait, in red): HOLOTYPE.

COMPARATIVE STUDY. As in the subspecies rectipes the aedeagus in lateral view is somewhat more 
robust than in the nominotypic subespecies and has a ventral expanded area. It is differentiated from lapidicola by the triangular, slightly curved metatibiae in the apical fourth; also, by the first segment of the male protarsi which is as wide as the distal extreme of the protibia, slightly narrower in lapidicola.

\section{The meridionalis new group}

Diagnosis. The male genitalia of Bathysciola meridionalis (Jacquelin du Val, 1854) was taken as the model. Median lobe of aedeagus (Fig. 43) curved just beyond central area, forming obtuse angle; apical part slightly shorter; four short setae inserted two by two (Fig. 44) in tip of lateral style; internal sac (Fig. 42) with a series of strongly sclerotised phanerae in median region (Fig. 42: PCM), an upper one and a smaller lower one, both tranversal, the ends of which are joined by a fairly sclerotised and strongly wrinkled tissue; in the central part, in axial position, strongly sclerotised floating nodule (Fig. 42: FN); inferior part of apical reinforcing bands (Fig. 42: ARB) with a sac (Fig. 42: SS), the tegument of which is strongly striate, with very sclerotised robust spines on the upper part. Spermathecal complex similar to B. finismillennii n. sp. (Fig. 37). Spermatheca curved from one end to the other and both lobes differentiated, their section being larger than that of the median region; spermathecal duct inserted in spermatheca via a nodule; expanded, striate and crossing a kind of sclerotised cylinder at the point where it joins the bursa copulatrix; spermathecal gland connected to terminal nodule of spermathecal duct, at the point where it joins the spermatheca. On evaluating the characters of the internal sac of the aedeagus, no similarity with any other model was found. It is true that the tip of the style has four setae, as in the Bathysciola of the schiodtei group, or Euryspeonomus Jeannel, 1919 or Speocharidius Jeannel, 1919; however, this is not a conclusive character in establishing relationships as there is also a species in this group with nine setae whose internal sac leaves no doubt of the taxonomic position of the meridionalis group. Three species.

GEOGRAPHICAL DISTRIBUTION. Western half of the northern slope of the Pyrenees, occasionally, some localities on the southern slope; also, the Garona river basin, as far as Bordeaux.

\section{Bathysciola (Bathysciola) (meridionalis group) finismillennii $\mathrm{n}$. $\mathrm{sp}$.}

TYPE SERIES. Holotype: one male from Grotte de Sabouche in Eycheil, Ariége (France), VII.1958, H. Coiffait leg. (stored in col. MNHNP). Paratypes: two males and two females with the same data as the holotype; two males and one female, Grotte de Sabouche, Eycheil, Ariége, 20.XI.2002. Eric Olivier leg., in col. E. Olivier and col. Fresneda.

DesCRIPTION. Body length: 2,30 mm. Oblong, oval-shaped and uniform. Surface covered in fine, yellowish, laid back pilosity. Pronotum transverse, with lateral margins uniformly arcuate and tegument marked with clear, dense disordered punctures with a dull appearance. Elytra lacking parasutural striae and sculpture formed by rugose points vaguely lined up transversally. Mesosternal carina low and uniformly arcuate. Legs proportionally short and first segment of male protarsi quadrangular, as wide as distal extreme of protibia.

Male Genitalia. Lobe of aedeagus (Fig. 35) strongly arcuate in central region, almost forming a right angle and the two resulting halves practically of the same length; nine long setae (Fig. 36) inserted in tip of lateral lateral style; median region of internal sac (Fig. 34) with a series of strongly sclerotized phanerae forming anular complex; in the centre, in axial position, there is a strongly sclerotized elongate nodule apparently floating; in the inferior part of the apical reinforcing bands there is a sac with a striate tegument.

Female Genitalia. Spermatheca (Fig. 37) uniformly curved from one end to the other and the two lobes differentiated, though their section is much larger than that of the median region; spermathecal duct inserted in the spermatheca via a nodule, and also expanded, striate and crossing a sclerotized cylinder at the point where it joins the bursa copulatrix.

Discussion. All the specimens in this group have a uniformly curved median lobe from one end to the other in lateral view, that is, the median curvature is large and the two resulting parts form a very obtuse angle, the distal part being smaller than the basal one (Figs. 35, 39 and 43); four setae of varying length -short (Fig 44) or long and twisted (Figs 36 and 40)- depending on the species, inserted in the apex of the lateral lateral lateral style. In B. finismillennii $\mathrm{n}$. sp. the median lobe is strongly curved in the central region almost forming a right angle, and the two resulting halves are practically of the same length (Fig. 35); nine long setae inserted in the tip of the lateral style (Fig. 36). B. meridionalis is the most 

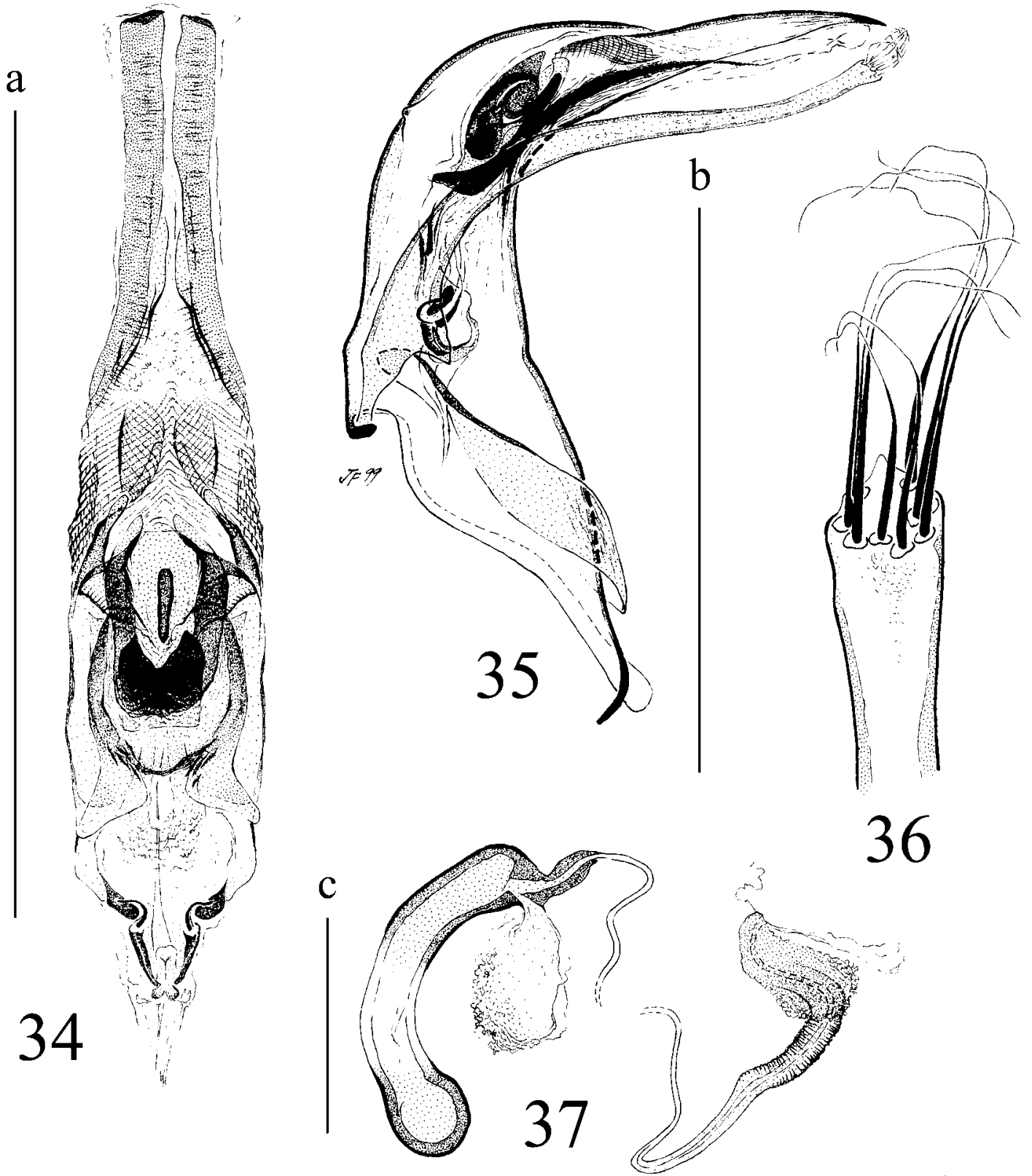

Figs. 34-37.-Bathysciola (Bathysciola) finismillennii sp. n. 34) internal sac of the aedeagus in dorsal view. 35) aedeagus in lateral view. 36) apical region of the lateral style. 37) spermathecal complex. Scale bar: a-b, $0.5 \mathrm{~mm}$ : 34, 35; c, $0.1 \mathrm{~mm}: 37$.

Figs. 34-37.-Bathysciola (Bathysciola) finismillennii sp. n. 34) vista dorsal del saco interno del edeago. 35) vista lateral del edeago. 36) región apical del estilo lateral. 37) complejo espermatecal. Scale bar: a-b, $0.5 \mathrm{~mm}: 34,35$; c, $0.1 \mathrm{~mm}: 37$.

similar of all the species in the group. It is practically impossible to differentiate it from this species by the external morphology and the internal sac of the aedeagus is also very similar; with a strongly sclerotized nodule in axial position in the upper part of the median region and a sac with a striate tegument. However, it can be differentiated from this species and others, as previously commented, by the 
supranummary setae on the tip of the lateral style of the aedeagus. The presence of numerous setae on the tip of the lateral style has already been described for other Iberian specimens in the genus Bathysciola: B. zariquieyi (with five or six setae), $B$. madoni (with eight to fourteen setae) and $B$. penicillata (with nine or ten setae). In any case these taxa are at a considerable distance from the species described because the model of internal sac of the aedeagus is completely different, and they are related to the Bathysciola in the aubei group. The specimens in the type series were found in the Coiffait collection (MNHNP) where they had been determined by this author as Bathysciola meridionalis. In the general collection of this museum there is another female specimen (Grotte d'Eycheil, 25.V.1897, J. Bepmale leg.) which is not included in the type series because as it is a female it cannot be determined with absolute certainty; however this specimen was presumibly studied by R. Jeannel in his revision (Jeannel, 1911) and he attributed it with doubts to Bathyscia nitidula; he states that he observed some differences in this taxon in the antennae and suggests the possibility of it being a new species. Years later in the monograph, no comment was made about including the specimen in the studied Bathysciola meridionalis (= Bathyscia nitidula).

ETYMOLOGY. This compound name is formed by the latin terms: finis (end), mille (thousand) and annus (year). The genitive indicates that it is the Bathysciola from the end of the millenium, as this species was discovered during the year two thousand on the Gregorian calendar.

\section{Bathysciola (Bathysciola) (meridionalis group) grenieri (Saulcy, 1872)}

Adelops grenieri Saulcy, 1872. in Abeille de Perrin, Synopsis des Adelops Pyrénéens: 22

Bathyscia (Bathyscia) grenieri (Saulcy): Reitter, 1885. Verh. naturforsch Ver. Brünn, 23(1884): 33

Bathyscia schioedtei subsp. grenieri (Saulcy): Jeannel, 1907. Ann. Soc. Entomol. Fr., 76: 423

Bathysciola schiodtei subsp. grenieri (Saulcy): Jeannel, 1910. Arch. Zool. exp. gén., 45(1): 29

Bathysciola (Bathysciola) schiodtei subsp. grenieri (Saulcy): Jeannel, 1914. Coleopterorum catalogus, pars 60: 10

Bathysciola (Bathysciola) grenieri (Saulcy): Jeannel, 1924. Arch. Zool. exp. gén., 63(1): 110

Bathysciola grenieri (Saulcy, 1872): Secq \& Secq, 1996. l'Entomologiste, 52(1): 10

Bathysciola (Bathysciola) grenieri (Saulcy): Perreau, 2000. Mém. de la SEF, 4: 236

MATERIAL STUDIED AND BIBLIOGRAPHICAL DATA. Lectotype male preserved in the MNHNP and labelled: 1. (hw): Vernet; 2. (i, in red): Collect. de Saulcy; 3. (i, in red): Cotype; 4. (i): Muséum Paris, Coll. F. P. de Saulcy, Coll. A. Argod. 1931; 5. (hw) grenieri; 6. (i, hw, in red): Lectotype male, Bathysciola grenieri (Saulcy), B. Secq dés. 1994. Paralectotypes five males and six females preserved at the MNHNP and labelled: 1. (hw): Vernet; 2. (i, in white or red): Collect. de Saulcy; 3. (i, in red): Type or Cotype; 4. (i): Muséum Paris, Coll. F. P. de Saulcy, Coll. A. Argod. 1931; 5. (hw) grenieri; 6. (i, hw, in red): Paralectotype male or female, Bathysciola grenieri (Saulcy), B. Secq dés. 1994. This species was recorded on one occasion from Andorra, without specifying the locality (Español, 1956).

Male genitalia. A series of specimens from Ax les Thermes, Ariége (France) was used for the description and illustrations. Base of aedeagus in lateral view (Fig. 39) robust and strongly folded in middle, apical half decreasing brusquely becoming very fine, tip prolonged and pointed or ending in small nodule; lateral style sinuous, as long as or slightly shorter than median lobe with tip expanded and club-shaped with nine (Fig. 36) or four setae of varying length (Figs. 40 and 44); in dorsal view internal sac of aedeagus (Fig. 38) characterised by strongly sclerotized complicated phanera superposed in median region; occasionally forming a type of ring with an interior space ocuppied by a floating nodule; upper extreme of phanerae and between reinforcing bands of apical region, there may be one or several sacs with a strongly striate tegument; in lateral view phanerae in median region forming a kind of parenthesis.

Discussion. This species is easily differentiated within its group as its relationship with $B$. finismillenni $\mathrm{n}$. sp. is as distant or as close as with B. meridionalis. The latter two species are a lot more similar to each other. Bathysciola grenieri and the other species have the same model of internal sac when observed in lateral view as they both have bracket-shaped phanerae, however, in dorsal view $B$. grenieri does not have strongly striate sacs, and the floating nodule inside the sclerotized ring in the other species is modified in this one, and formed by three phanerae joined by one end, resembling the letter $\mathrm{T}$. The description by Saulcy does not specify the number of specimens studied. Lectotype and paralectotypes were erroneously designated in the study by Secq \& Secq (1996). The lectotype and paralectotypes in fact correspond to Adelops grenieri, not to Bathysciola grenieri as indicated on the labels included by Secq and as indicated in the mentioned study.

\section{Bathysciola (Bathysciola) (meridionalis group) meridionalis (Jacquelin du Val, 1854)}

Adelops meridionalis Jacquelin du Val, 1854. Ann. Soc. entomol. Fr. (Bull. séances), 23: 36 


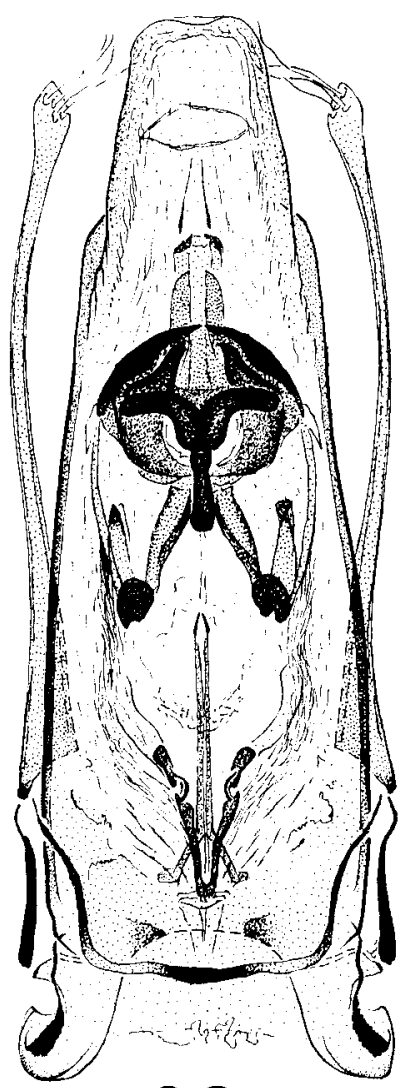

a
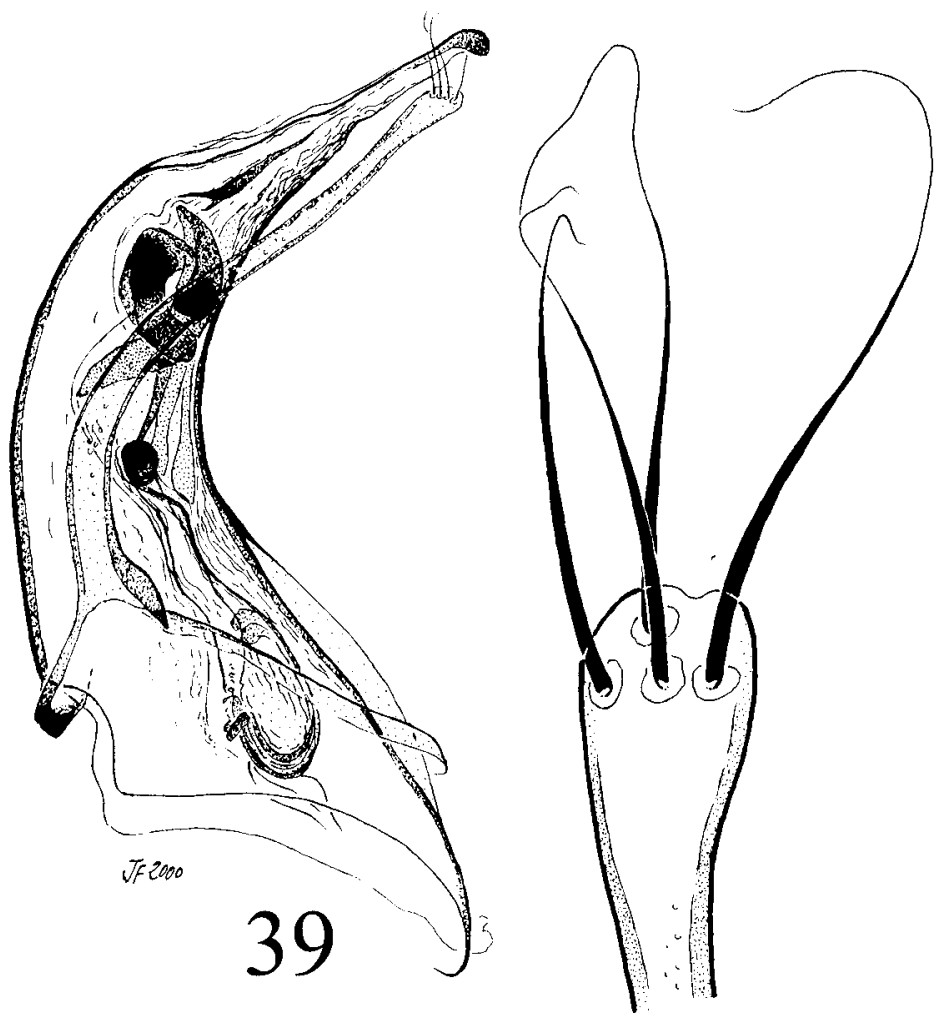

38

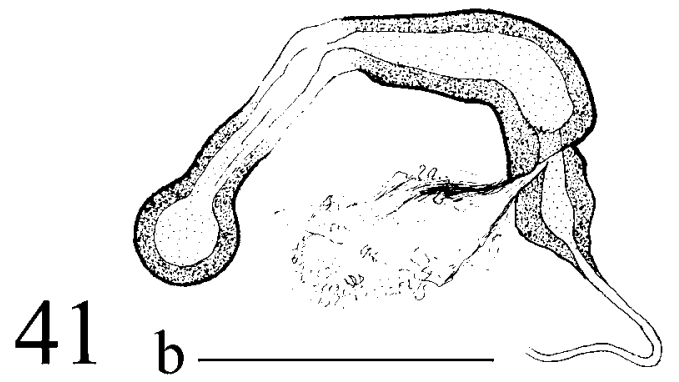

40

Figs. 38-41.- Bathysciola (Bathysciola) grenieri. 38) aedeagus and internal sac in dorsal view. 39) aedeagus in lateral view. 40) apical region of the lateral style. 41) spermatheca. Scale bar: a, $0.5 \mathrm{~mm}: 38,39$; b, $0.1 \mathrm{~mm}: 41$.

Figs. 38-41.- Bathysciola (Bathysciola) grenieri. 38) edeago y vista dorsal del saco interno. 39) vista lateral del edeago. 40) región apical del estilo lateral. 41) espermateca. Escala: a, $0.5 \mathrm{~mm}: 38,39 ;$ b, $0.1 \mathrm{~mm}: 41$.

Bathyscia (Bathyscia) meridionalis (J. du Val): Reitter, 1885. Verh. naturforsch. Ver. Brünn, 23(1884): 33

Bathyscia meridionalis (J. du Val): Delherm de Larcenne, 1890. Feuille des jeunes naturalistes, 21(242): 36

Bathyscia nitidula Normand, 1907. Bull. Soc. entomol. Fr., 12: 272

Bathysciola meridionalis (J. du Val): Jeannel, 1910. Arch. Zool. exp. gén., 45(1): 29

Bathysciola (Bathysciola) meridionalis (J. du Val): Jeannel, 1914. Coleopterorum catalogus pars 60: 10
Bathysciola (Bathysciola) meridionalis (J. du Val): Perreau, 2000. Mém. de la SEF, 4: 237

MATERIAL STUDIED. The number of specimens studied was not indicated in the original description (Jacquelin du Val, 1854). Two specimens belonging to the type series were found, preserved in the general collection at the MNHNP, fixed on a transparent lamina and labelled: first specimen: 1. (i): TYPE; 2.: (i) MUSÉUM PARIS / (hw) coll / (hw) J. du Val; 3. (hw du Val): meridionalis / J. du V. Second specimen also fixed on a 


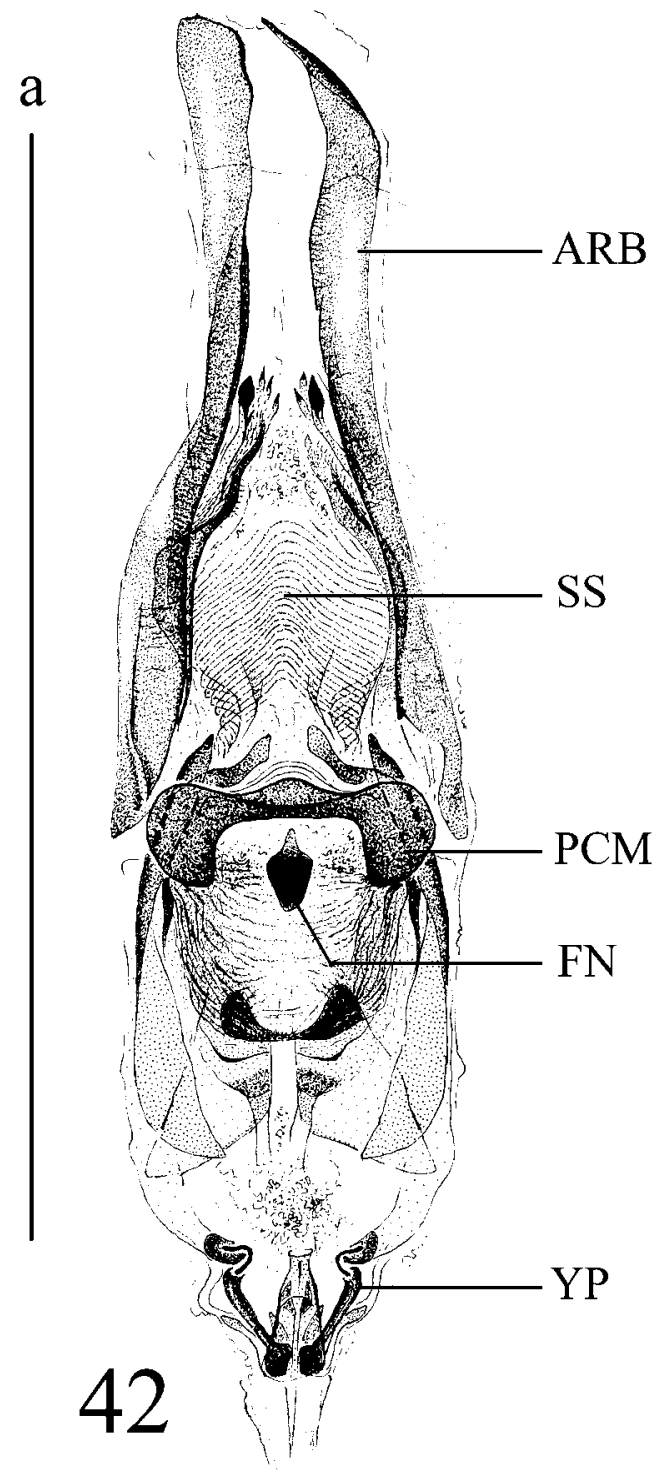

transparent lamina and labelled: 1. (i, in red): COTYPE; 2.: (i) MUSÉUM PARIS / (hw) coll / (hw) J. du Val. Sub. nitidula. In the MNHNP general collection two specimens belonging to the type series of nitidula labelled as follows were studied: first specimen: 1. (i): Ar. / Gr. de Portel / Dr. Normand; 2. (i, in red) COTYPE; 3. (i): MUSÉUM PARIS / Coll. R. Jeannel 1931; 4 (hw): nitidula / Norm. Both specimens have the label "COTYPE". The specimen used in the original description has not been found. The original description (Normand, 1907) does not indicate the number of specimens in the type series. There are two more specimens in the MNHNP: F-Ar., Grotte de Portel, VI.1920, RJ leg., 2 exs.; with the following label handwritten by Jeannel: nitidula.

Male Genitalia. The genital structures of $B$. meridionalis were chosen as the model for charac-

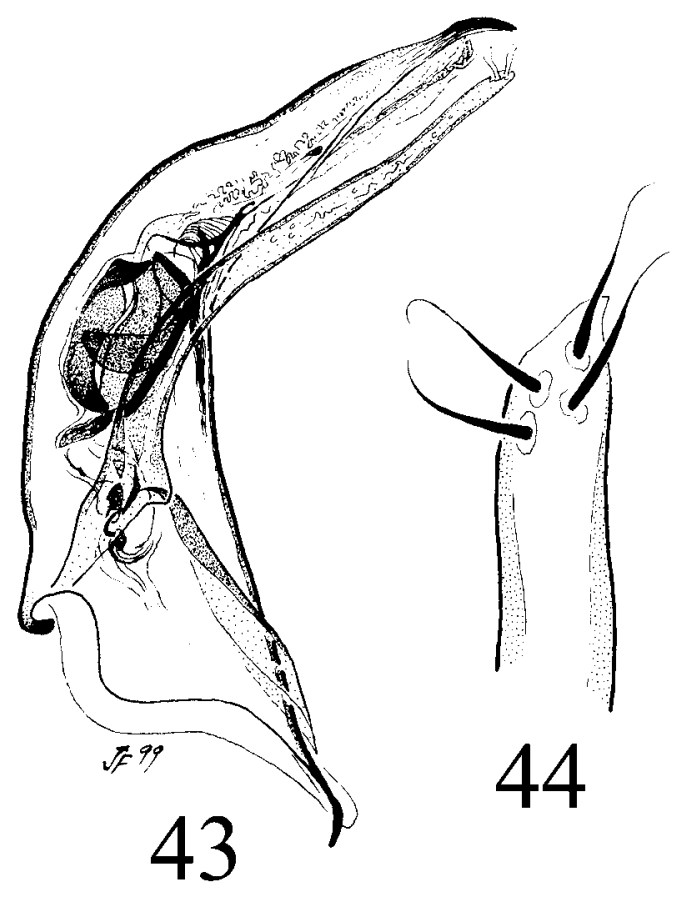

Figs. 42-44.-Bathysciola (Bathysciola) meridionalis. 42) internal sac of the aedeagus in dorsal view. 43) aedeagus in lateral view. 44) apical region of the lateral style. Scale bar: a-b, 0.5 $\mathrm{mm}: 42,43$. ARB, apical reinforcement band; FN, floating nodule; PCM, phanerae complex of the medial region; SS, striated sac; YP, Y-shaped piece.

Figs. 42-44.-Bathysciola (Bathysciola) meridionalis. 42) vista dorsal del saco interno del edeago. 43) vista lateral del edeago. 44) región apical del estilo lateral. Escala: a-b, $0.5 \mathrm{~mm}: 42,43$. $\mathrm{ARB}$, banda de refuerzo apical; FN, nódulo flotante; PCM, complejo de faneras de la región media; SS, saco estriado; YP, pieza en forma de Y.

terising the group: internal sac of the aedeagus (Fig. 42), aedeagus in lateral view (Fig. 43) and tip of the lateral style (Fig. 44).

Discussion. The type series comes from Bordeaux. The male genitalia was illustrated using a series of specimens from Monferran, in the department of Gers, France. Of the species in the group the most similar one is $B$. finismillennii $\mathrm{sp}$. $\mathrm{n}$. The internal sac of the aedagus of these two taxa has the same layout and appearance: with a strongly sclerotized nodule in axial position in the upper part of the median region and a large sac with a strongly striate tegument. However, there 
are easily discernible differences between the respective sacs, as can be seen in figures 42 (B. meridionalis) and 34 (B. finismillennii sp. n.). The shape of the median lobe is also different, it is longer and more angulose in B. finismillennii sp. n., and there are nine setae inserted in the tip of the lateral style of this species compared with four in B. meridionalis.

\section{The larcennei new group}

DiAgnosis. The male genitalia of the species Bathysciola larcennei (Abeille de Perrin, 1883) is taken as the model. A series of specimens from Pordiac in Gers, France was used in the description and illustrations. In lateral view (Fig. 49) median lobe of aedeagus strongly expanded ventrally in basal region and folded in uniform curve just before half its length; distal half gradually decreasing and tip pointed and slightly curved ventrally. Lateral style slightly shorter than median lobe, bearing four long subequal setae and a membranous lamina on tip (Fig. 50). Upper area of median region of internal sac of aedeagus (Fig. 48) with two small phanerae joined together by a small sclerotized bridge (Fig. 48: PM); in lower region and at a distance from these phanerae there is a transversal lamina (Fig. 48: TL) bearing two fine long superposed phanerae set out obliquely; inferior region of these phanerae with two identical nodules (Fig. 48: SN) with a peduncle prolonged to the area near the Y-shaped piece (Fig. 48: YP). Facies of internal sac of aedeagus number, shape and layout of sclerotized shieldshow no great similarity with any of the other models described. Apart from the differences there is some similarity with the model of the schiodtei group in the layout of the groups of phanerae: two situated at both ends of the median region. As in the meridionalis or schiodtei groups the tip of the lateral style has four setae which also occurs in the Basque-Navarre genera Euryspeonomus or Speocharidius; as previously indicated, this is not a determining character when establishing degrees of relationship if it is not as a complement of other more conclusive ones. The need to study the other genera of Leptodirinae inhabiting these territories, is underlined. Two species.

GEOGRAPHICAL DISTRIBUTION. Northern slope of the central Pyrenees, in the departments of Gers, Haute Garonne and Hautes Pyrénées (France).

\section{Bathysciola (Bathysciola) (larcennei group) convena} Jeannel, 1924 new rank

Bathysciola (Bathysciola) larcennei subsp. convena Jeannel, 1924. Arch. Zool. exp. gén., 63 (1): 92

Bathysciola larcennei subsp. convena Jeann.: Coiffait, 1952. Notes biospéol., 7: 44

Bathysciola larcennei convena Jeannel, 1924: Secq \& Secq, 1996. l'Entomologiste, 52 (1): 12

Bathysciola (Bathysciola) larcennei convena Jeannel: Perreau, 2000. Mém. de la SEF, 4: 237

MATERIAL STUDIED. The number of specimens is not indicated in the original description. Lectotype and paralectotypes are designated in the study by Secq \& Secq (1996). Lectotype male labelled: 1. (hw): Grotte de Gargas; 2. (hw): H. Pyr., R. J., 944, 17.VIII.19; 3. (i, in red): Type; 4. (i): Muséum Paris, Coll. R. Jeannel. 1931; 5. (i, hw): Lectotype male, Bathysciola larcennei convena Jeannel, B. Secq dés. 1994. Paralectotypes one male and two females labelled: 1. (hw): Grotte de Gargas; 2. (hw): H. Pyr., R. J., 944, 17.VIII.19; 3. (i or hw, in red): Type; 4. (i or hw): Muséum Paris, Coll. R. Jeannel. 1931; 5. (i, hw): Paralectotype male or female, Bathysciola larcennei convena Jeannel, B. Secq dés. 1994.

Male Genitalia. In lateral view (Fig 46) basal region of median lobe weakly expanded ventrally and folded in uniform curve just before half its length; distal region decreasing gradually with dorsus somewhat depressed; tip pointed and slightly curved in ventral part. Lateral style a little shorter than median lobe, with four long twisted setae of similar length at tip (Fig 47). In the upper part of the median region of the internal sac of the aedeagus (Fig 45) there are two small pilous strongly sclerotized phanerae; in the inferior region and at a distance from them there are dorsal and ventral phanerae of peculiar shape, formed by a number of twisted laminas.

Discussion. A series of specimens from the Grotte de Gargas, Ariège (France) was used for the description of the male genitalia. This taxon was described (Jeannel, 1924a) as a subspecies of Bathysciola larcennei, and its status had not been modified. The differences observed amongst their respective genital structures justifiy the independance of both species. The median lobe of the aedeagus in lateral view is similar in both species, however a closer study reveals some subtle differences: in B. convena (Fig. 46) the basal region is thick but has no peculiar expanded areas and the distal half decreases gradually with the dorsus slightly depressed; however, in $B$. larcennei there is a prominent rounded lump in the ventral area (Fig. 49). The lateral style of $B$. convena (Fig. 47) do not have a membranous lamina at the tip, but $B$. larcennei (Fig. 50) does. The internal sac of the aedeagus though of the same model in both species, has 

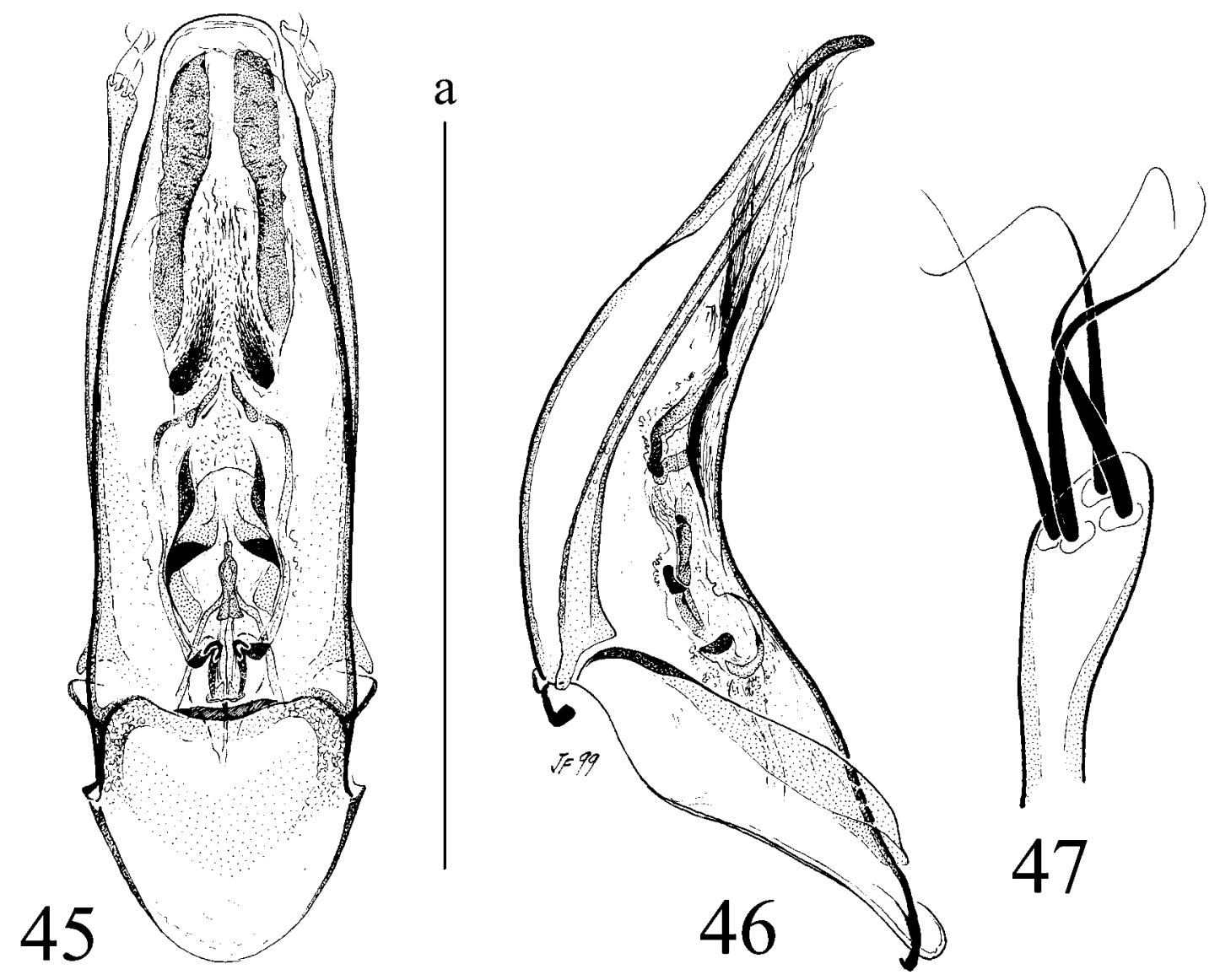

Figs. 45-47.- Bathysciola (Bathysciola) convena new rank. 45) aedeagus and internal sac in dorsal view. 46) aedeagus in lateral view. 47) apical region of the lateral style. Scale bar: a, $0.5 \mathrm{~mm}: 45,46$.

Figs. 45-47.- Bathysciola (Bathysciola) convena nuevo rango. 45) edeago y vista dorsal del saco interno. 46) vista lateral del edeago. 47) región apical region del estilo lateral. Escala: a, $0.5 \mathrm{~mm}: 45,46$.

very different pieces: the upper part of the median region in $B$. convena has two small pilous strongly sclerotized phanerae whereas in $B$. larcennei there are two smooth phanerae formed by a number of lamina joined together by a small sclerotized bridge; the differences in all the pieces of the sclerotized shield are numerous (Figs. 45 and 48).

\section{Bathysciola (Bathysciola) (larcennei group) larcennei (Abeille de Perrin, 1883)}

Bathyscia larcennei Abeille de Perrin, 1883. In Delherm de Larcenne: Catalogue des Coléoptères du Gers et du Lot et Garonne, appendice 1: 1

Bathyscia lucantei Abeille de Perrin, 1883. In Delherm de Larcenne. Catalogue des Coléoptères du Gers et du Lot et Garonne, appendice 3: 9
Bathyscia (Bathyscia) larcennei Abeille de Perrin: Reitter, 1885. Verh. Naturforsch. Ver. Brünn, 23(1884): 33

Bathyscia schioedtei subsp. larcennei Abeille de Perrin: Jeannel, 1907. Ann. Soc. entomol. Fr., 76: 423

Bathysciola (Bathysciola) larcennei (Abeille de Perrin): Jeannel, 1924. Arch. Zool. exp. gén., 63(1): 109

Bathysciola larcennei larcennei (Abeille de Perrin): Secq \& Secq, 1996. l'Entomologiste, 52(1): 11

Bathysciola (Bathysciola) larcennei larcennei (Abeille de Perrin): Perreau, 2000. Mém. de la SEF, 4: 237

Material StUdied. Lectotype female labelled: 1. (hw): Pordiac, 2 oct. 79; 2. (i, in red): Type; 3. (i): Muséum Paris, Coll. Abeille de Perrin, 1919; 4. (hw): larcennei Ab.; 5. (i, hw, in red): Lectotype femelle, Bathysciola larcennei (Abeille), B. Secq dés. 1994. Paralectotypes three males, four females and three other specimens in poor condition. The different specimens has one of these four labels: 1. (hw): Pordiac; (hw): Pordiac, Gers, Delherm; (hw): Pordiac, Gers, ex. Coll. Larcenne; 4. (hw): larcennei Ab., Pordiac; (hw): de Larcenne, Gers; (i or hw, depen- 


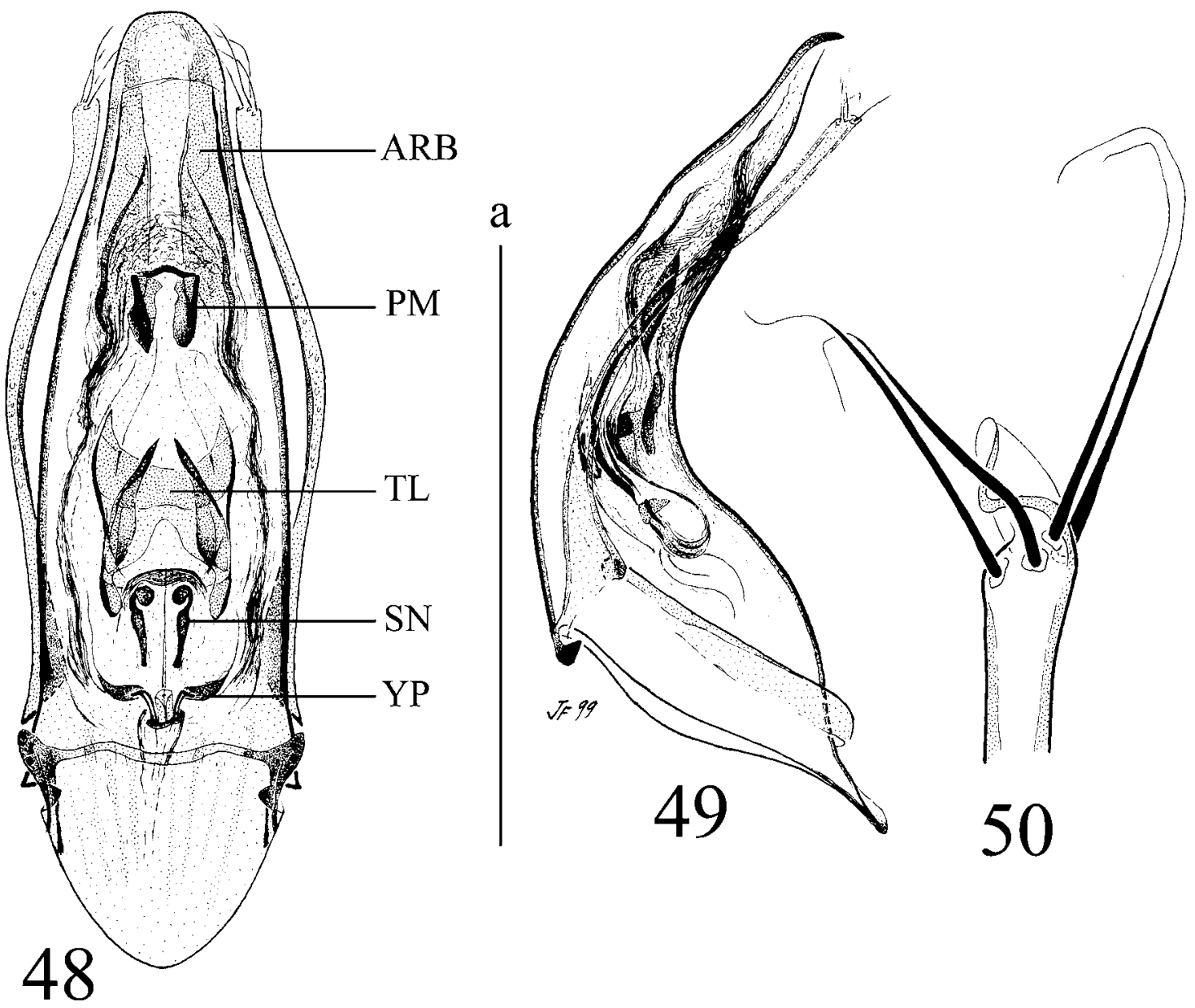

Figs. 48-50.-Bathysciola (Bathysciola) larcennei. 48) aedeagus and internal sac in dorsal view. 49) aedeagus in lateral view. 50) apical region of the lateral style. Scale bar: a, $0.5 \mathrm{~mm}$ : 48, 49. ARB, apical reinforcement band; PM, phanerae of the medial region; $\mathrm{SN}$, sclerotized nodule; TL, transversal lamina; YP, Y-shaped piece.

Figs. 48-50.- Bathysciola (Bathysciola) larcennei. 48) edeago y vista dorsal del saco interno. 49) vista lateral del edeago. 50) región apical del estilo lateral. Escala: a, $0.5 \mathrm{~mm}$ : 48, 49. ARB, banda de refuerzo apical; PM, faneras de la región media; SN, nódulo esclerotizado; TL, lámina trasnversal; YP, pieza en forma de Y.

ding on the specimens): Muséum Paris, Coll. Abeille de Perrin, 1919; (i in three specimens; hw in three specimens): Muséum Paris, Coll. R. Jeannel, 1931; (i in two specimens): Muséum Paris, 1932, Coll. Sainte-Claire Deville; (hw, in red in one specimen): Type; 9 . ( hw, in red in five specimens): larcennei, Type; 10. (i, hw, in red): Paralectotypes male, femelle, Bathysciola larcennei (Abeille), B. Secq dés. 1994.

Male Genitalia.- The genital structures of $B$. larcennei were used to characterise the group; aedeagus in dorsal view and internal sac by transparency (Fig. 48), aedeagus in lateral view (Fig. 49) and tip of lateral style (Fig. 50).
Discussion. It is differentiated from the other species in the genus in the discussion on $B$. convena. In the description by Abeille de Perrin the number of specimens studied is not indicated. The lectotype and paralectotypes were erroneously designated in the study by Secq \& Secq (1996). This series of specimens corresponds, in fact, to Bathyscia larcennei and not to Bathysciola larcennei as indicated by the labels that Secq \& Secq (1996) included and as stated in the study carried out by these authors. 
The schiodtei group of Perreau, 2000

Groupe schioedtei of Perreau, 2000. Mém. de la SEF, 4: 236

Diagnosis. The male genitalia of the Bathysciola schiodtei (Kiesenwetter, 1850) was taken as the model. A series of specimens from Vielha, Lérida (Spain) was used for the description and illustrations. For the spermathecal complex, specimens of $B$. rugosa from Dolina de Orobe in Alsásua, Navarra (Spain). The median lobe in lateral view (Fig. 81) is long, weakly arquate, uniformly decreasing from the base to the tip and with a sinuous dorsal face; the lateral style are as long as the median lobe, pointed and bearing four setae (Fig. 82); the internal sac of the aedeagus (Fig. 80) divided into three areas: in the basal region the Yshaped piece (Fig. 80: YP) formed by two very fine symmetrical rods with a thick bean-shaped nodule articulated by a tubule with another nodule of the same characteristics, at the tip, there are phanerae next to the Y-shaped piece (Fig. 80: NPYP); in the median region ventral (Fig. 80: VPM) and dorsal (Fig. 80: DPM) phanerae weakly sclerotized, not easily discernible; a number of well-defined phanerae visible on both sides of the sac (Fig. 80: LPM); at the end of the median region there are some strongly sclerotized nodules articulated amongst each other (Fig. 80: PC); in the apical region reinforcing bands (Fig. 80: ARB) resting upon sclerotized nodules (Fig. 80: SN). Spermatheca (Fig. 79) curved from one end to the other and median region very thin; both lobes differentiated, the basal one being much larger and more elongate than the apical one: the spermathecal duct is long and fine, and expanded near the bursa copulatrix where it crosses a sclerotized disk; a spermathecal gland can be seen. The schiodtei group is related to the genera inhabiting the Basque-Navarre region, Euryspeonomus and Speocharidius having in common the tips of the lateral style of the aedeagus armed with four differentiated setae and phanerae next to the Y-shaped piece in the basal region of the internal sac. The differences amongst the described taxa in this group are clear and consistent for all the studied specimens; they are all considered valid as they are clearly characterised. However, the differences are not extremely important and the problem arises when assigning a taxonomical category to them: species or subspecies. There are two possible solutions: subordinate all the taxa as subpecies of the oldest taxon or consider all of them as good species. Data in entomological literature demonstrate that the Leptodirinae species do not have very wide distribution areas: the observations made by the authors of this study are along the same line. So the second option has been chosed, that is, to consider practically all the described taxa as species.

GEOGRAPHICAL DISTRIBUTION. The specimens in this group inhabit the Pyrenean mountains, in particular both slopes of the western half, where they diversified into numerous taxa. They also inhabit the northern areas, following the course of the river Garona to its mouth and there is a considerably isolated population in the region of Calvados, northern France. The group probably invaded the Pyrenees going from west to east as phylogenetically similar genera: Euryspeonomus and Speocharidius are found in the western extreme Basque-Navarre territory. It is the only genus of the series that has moved east, perhaps due to being less developed and therefore less capable of colonizing any cryptic habitat, such as forests area that probably stretched uninterrupted between these regions and between both slopes of the Pyrenees.

\section{Bathysciola (Bathysciola) (schiodtei group) bigerrica Jeannel, 1930 new rank}

Bathysciola (Bathysciola) parallela subsp. bigerrica Jeannel, 1930. Bull. Soc. entomol. Fr., 35: 224.

Bathysciola (Bathysciola) schiodtei subsp. convexa Coiffait, 1959. Ann. Spéléol., 14(1-2): 160. n. syn.

Material STUdied. Subsp. bigerrica: the original description only states: "Type: un mâle de Aspeigt" (Jeannel, 1930). This specimen is stored in the MNHNP general collection and labelled: 1. (i): Ossau / Aspeigt; 2. (hw): Hustache; 3. (i): TYPE; 4. (i): MUSÉUM PARIS / Coll. R. Jeannel 1931. Subsp. conve$x a$ : the number of specimens is not indicated in the original description, only: "Type dans ma collection" (Coiffait, 1959). This specimen is stored in the Coiffait collection at the MNHNP and labelled: 1.: (i) B. Pyrénées / (hw Coiffait) LARRAU / (i) H. Coiffait / (hw Coiffait) 22.9.49; 2. (hw Coiffait): Grotte / Aker leccia; 3. (hw Coiffait, in red): TYPE.

Male Genitalia. In lateral view (Fig 52) median lobe long, weakly arcuate and uniformly decreasing from base, which is very thick to tip with slightly concave face just before; styl lateral style us almost as long as median lobe, pointed and bearing four strongly folded setae similar in length (Fig. 53); in the internal sac of the aedeagus (Fig. 51) there are some phanerae next to the weakly sclerotized Y-shaped piece; in the median region the ventral phanerae are well sclerotized and appear to form the interior margin of translucent laminas; the dorsal ones are hyaline; there are a number of short phanerae can be seen along the sides of the sac, which are not strongly sclerotized and rest upon the laminas of the ventral phanerae; the basal 


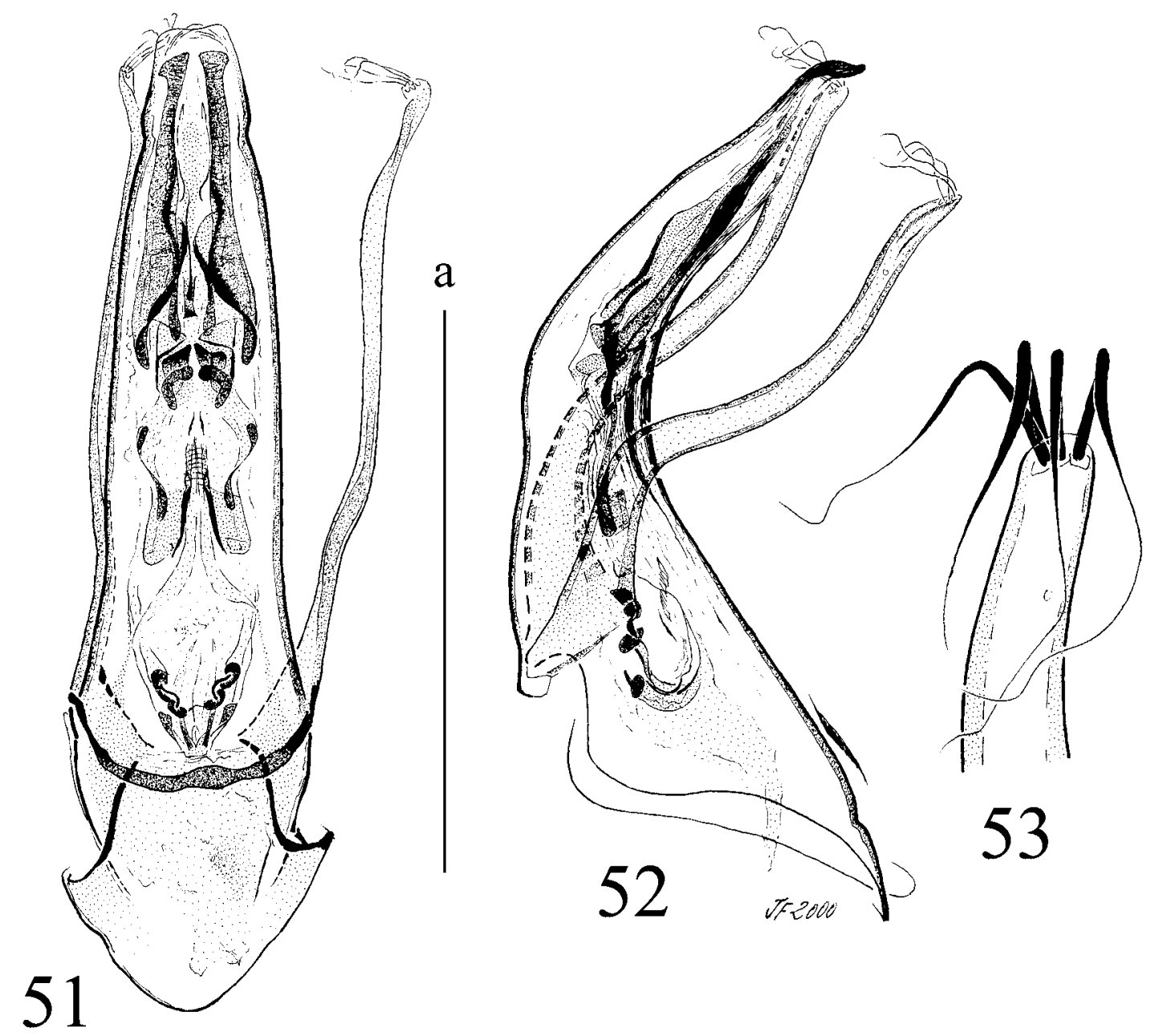

Figs. 51-53.- Bathysciola (Bathysciola) bigerrica new rank. 51) aedeagus and internal sac in dorsal view. 52) aedeagus in lateral view. 53) apical region of the lateral style. Scale bar: a, $0.5 \mathrm{~mm}: 51,52$.

Figs. 51-53.- Bathysciola (Bathysciola) bigerrica nuevo rango. 51) edeago y vosta dorsal del saco interno. 52) vista lateral del edeago. 53) región apical del estilo lateral. Escala: a, $0.5 \mathrm{~mm}: 51,52$.

nodules of the phaneroid complex are folded in an acute angle; the interior margin of the reinforcing bands is noticeably expanded, sclerotized and prolonged forming peduncles; amongst the reinforcing bands there is a tiny tubule with a fine rod

Discussion. Bathysciola bigerrica was described (Jeannel, 1930) as a subspecies of B. parallela. The differences observed in the latter species have led to this taxon being considered a species for questions of coherence with the criterion applied in this revision. It is similar to a number of species in its own group that have a clearly defined structure between the reinforcing bands of the internal sac of the aedeagus, which is either a tubule, a rod or both; these species are: $B$. bigerrica, $B$. diegoi, $B$. grandis, B. parallela and B. obermaieri. In any case $B$. bigerrica and B. parallela are closely related as they are the only species with the unusual character of a pendunculate lower extreme of the reinforcing bands in common. Identification is made possible by numerous genital characters (Figs. 51 and 73) though the robustness, size and degree of sclerotization of the phanerae of the median region of the internal sac is possibly the most apparent. 


\section{Bathysciola (Bathysciola) (schiodtei group) breuili} Bolívar, 1921

Bathysciola (Bathysciola) breuili Bolívar, 1921. Bol. Soc. esp. Hist. nat., T. $50^{\circ}$ aniv.: 525

Bathysciola (Bathysciola) schiodtei subsp. breuili Bolívar, 1921: Jeannel, 1924. Arch. Zool. exp. gén., 63(1): 110 Bathysciola (Bathysciola) schioedtei breuili Bolívar: Perreau, 2000. Mém. de la SEF, 4: 238

Bathysciola (Bathysciola) azuai Bolívar, 1921. Bol. Soc. esp. Hist. nat., T. $50^{\circ}$ aniv.: 524

Material STUdied. Subsp. breuili: in the original description Bolívar (1921), the author states that he collected and studied various specimens collected by $\mathrm{H}$. Breuil and R. Jeannel on 18th August, 1919; he also states that the "Tipo: macho..." is in col. Biospeologica (in the MNHNP) and the remaining specimens divided between this museum and the MNCNM. The following species belonging to the type series were found: one specimen stored in the MNHNP general collection and labelled:: 1. (hw) 1.945 cuev. de Landarbaso; 2. Guipuzcoa RJ VIII-19; 3. Bathysciola breuili C. Bol.; 4. (i, in red) COTYPE. Two specimens preserved in the MNHNP general collection and labelled: 1. (hw) 1.945 cuev. de Landarbaso; 2. Guipuzcoa RJ VIII-19; 3. Bathysciola breuili C. Bol.; 4. (i, in red): COTYPE. Two male and female specimens preserved in the MNCNM general collection; the first specimen: 1. (hw) 945 cuev. de Landarbaso; 2. Guipuzcoa RJ VIII-19; 3. Bathysciola breuili C. Bol.; 4. (i) MNCN / MADRID. The second specimen: 1. (hw) 945 cuev. de Landarbaso; 2. (hw) Guipuzcoa R. Jeann. VIII-19; 3. (i) MNCN / MADRID. Subsp. azuai: in the description Bolívar (1921) the author claims to have collected and studied three specimens which have been located in the museums indicated by these author. One male ("Tipo: macho...". Bolívar, 1921) stored in the MNCNM collection and labelled: 1. (hw Bolívar): Gorbea 28.8.1919; 2. (i): Prov. Alava P. BOLIVAR; 3. (hw Bolívar): Bathysciola azuai C. Bol. TIPO. Another specimen in the MNHNP general collection labelled: 1.: (hw) Bathysciola / feuilles mortes Gorbeas; 2.: (i, in red) TYPE; 3.: (i) MUSÉUM PARIS / Coll. R. Jeannel 1931; 4.: (hw) Bathysciola / Azuai C. Bol. Besides the type series the following specimens have been studied: S-VI, Murúa, Embalses de Gorbeia, 25.IV.1999, JF leg., 3 males and 1 female stored in col. JF; S-VI, Murúa, beech forest near the Cueva Mairuelegorreta, 2000, JF and Salgado leg., 16 exs. stored in col. JF and col. Salgado; there is another specimen in the MNCNM collection: S-SS, Rentería, Cueva de Landarbaso, VIII.1923, Abajo leg., 1 male. Another labelled specimen from the MNHNP has been studied: Peña de Gorbea, $1000 \mathrm{~m}$, feuilles, IX.1919, R. Jeannel.

Male Genitalia. Median lobe of aedeagus in lateral view (Fig. 55) curved in mid region and preapically bisinuate; style with four long subequal setae at tip set out in twos and intricately twisted (Figs. 56 and 57); internal sac (Fig. 54) with very fine, weakly sclerotized exterior phanerae; basal phanerae of phaneroid complex strongly folded in obtuse angle; reinforcing bands expanded in basal region forming laminas almost touching in the axis of symmetry of sac.
FEMALE GENITALia. Spermathecal complex coinciding with description given for the genus, spermatheca (Fig. 58) proportionally short and robust, with two noticeably expanded lobes.

Discussion. Specimens from the Cueva de Landarbaso, in Rentería (Guipúzcoa) were used in the description of the genitalia. This species was described as a species (Bolívar, 1921) and shortly afterwards (Jeannel, 1924a) was included as subspecies of $B$. schiodtei. Nevertheless, the exclusive characters of the internal sac of the aedeagus, and a curious secondary sexual character not seen in the genus, justify its status as valid species. This taxon should be included in the schiodtei group which has no differentiated structure amongst the reinforcing bands; these species are: $B$. breuili, B. fauveli, $B$. rugosa and $B$. schiodtei. The most similar amongst them is $B$. rugosa as they have very similar basal nodules in the phaneroid complex: in an acute angle in B. breuili and obtuse in B. rugosa. In contrast, the other two species in the subgroup have rectilinear nodules with an nocked inferior margin. The lateral phanerae of the internal sac are robust and strongly sclerotized in $B$. rugos $a$, whereas in $B$. breuili they are hyaline and finer; the phanerae adjacent to the Y-shaped piece are very evident in B. breuili but in B. rugosa they are almost invisible. Also, in B. breuili there is a femoral spine in the male metafemurs, not present in B. rugosa or the other taxa in the genus; a tiny undulated area can be seen in $B$. diegoi only, where the femoral spine would be, if it existed. This study verified that $B$. azuai and $B$. breuili are the same species. As both names were published in the same study by the author (Bolívar, 1921) it was first thought that it should come before azuai which appears on page 524 before breuili named on page 525; however, breuili was chosen as it is better characterized, also, the genital structure of the type series is in better condition and has therefore been studied; on the other hand the genitalia of the specimens of the type series of azuai is not preserved so must have been misplaced.

\section{Bathysciola (Bathysciola) (schiodtei group) diegoi Salgado \& Fresneda, 2000}

Bathysciola diegoi Salgado \& Fresneda, 2000. Elytron, 14: 184

Material StUdied. Holotype: male from Cueva de Mendia Landa, Arive (Navarra), 19.7.2000, Rodríguez, Salgado \& Fresneda leg. Stored in col. Fresneda (Llesp). Paratypes: 4 males and 8 females with the same collection data as the holotype. Preserved in the collections of the authors and the Zoology 

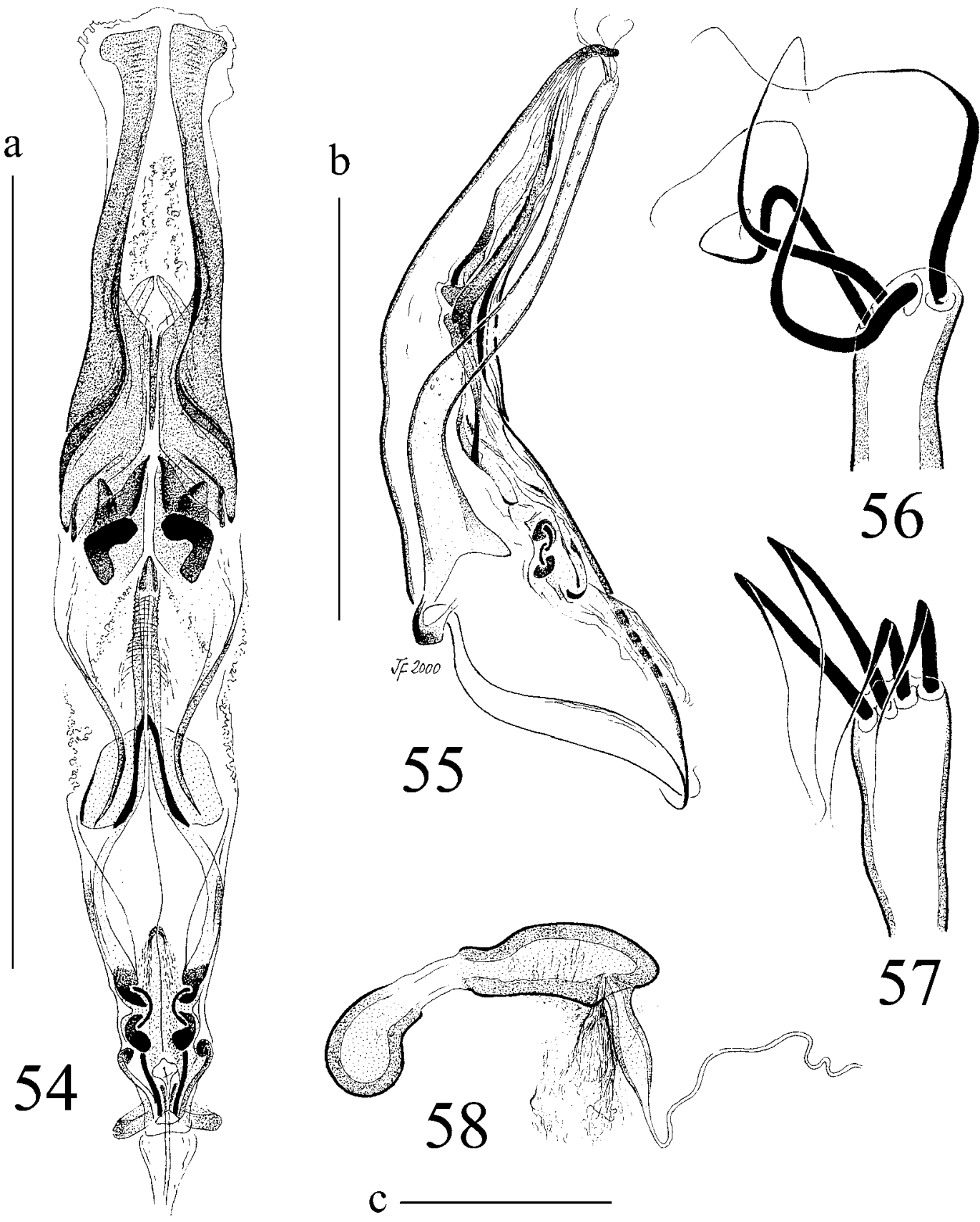

Figs. 54-58.- Bathysciola (Bathysciola) breuili. 54) internal sac of the aedeagus in dorsal view. 55) aedeagus in lateral view. 5657) apical region of the lateral style. 58) spermatheca. Scale bar: a-b, $0.5 \mathrm{~mm}: 54,55$; c, $0.1 \mathrm{~mm}: 58$.

Figs. 54-58.- Bathysciola (Bathysciola) breuili. 54) vista dorsal del saco interno del edeago. 55) vista lateral del edeago. 56-57) región apical del estilo lateral. 58) espermateca. Escala: a-b, $0.5 \mathrm{~mm}: 54,55$; c, $0.1 \mathrm{~mm}: 58$. 
Museum in Barcelona. The following material from the same locality has also been studied: trap: 19.7.2000/13.4.2001, JF leg., 1 ex.; 13.4.2001, JF \& Escoll leg., 2 exs.

Male Genitalia. Median lobe of aedeagus (Fig. 60 ) folded approximately in the middle in an obtuse angle; basal half strongly robust and dorsal face sinuous, especially in basal part. Tip of style (Fig. 61) has four long sinuous setae of similar length. Internal sac of aedeagus (Fig. 59) divided into three parts: in basal region Y-shaped piece formed by two very fine symmetrical rods with a stout bean-shaped nodule articulated by a tubule with another nodule in the same shape at the tip; there are some phanerae next to the Y-shaped piece; in median region with ventral and dorsal phanerae and two very long exterior ones, in the upper area of the median region there is phaneroid complex formed by three strongly sclerotized nodules articulated amongst each other, basal ones rectilinear with inferior nocked margin; in apical region reinforcing bands expanded in basal part forming laminas that almost touch the axis of symmetry of the sac, where a tubule can be seen.

Female Genitalia. Spermatheca (Fig. 62) discreetly curved from one end to the other and median region thin; both lobes differentiated, the basal one being larger and more elongate than the apical one; spermathecal duct 13-14 times longer than spermatheca becoming thinner as it gets nearer to the spermatheca forming a long stout nodule at the point of insertion with the spermatheca; also, it is larger near the bursa copulatrix, where it crosses a sclerotized disk; the spermathecal gland opens out near the insertion point with the spermatheca.

DisCUSSION. The specimens in the type series from the Cueva de Mendia Landa, in Arive (Navarre) were used to illustrate the genitalia. Bathysciola diegoi should be included with those in the group with a tubule or rod amongst the reinforcing bands of the internal sac of the aedeagus. The general structure of the internal sac of $B$. diegoi is very similar to that of $B$. obermaieri (Figs. 59 and 69 ), but there are differences in the shape and layout of some of its sclerotized pieces; there are also some differences in the median lobe and spermatheca.

- Bathysciola diegoi: in the phaneroid complex the upper phanera is a simple triangular lamina; the intermediate one is in the shape of a triangular tooth and also a flat lamina; the ventral and lateral phanerae are strongly sclerotized and robust (Fig. 59). The dorsal area of the median lobe is more sinuous and the basal part is less robust
(Fig. 60). The spermatheca (Fig. 62) is shorter and robust, with the apical lobe proportionally larger; the spermathecal duct is inserted in the spermatheca by a stout elongate nodule.

- Bathysciola obermaieri: in the phaneroid complex the upper phanera forms a triangular lamina with two expanded margins; the intermediate one is elongate and the upper margin expanded, protruding towards the axial line of the sac; the ventral and lateral phanerae are more slender and weakly sclerotized (Fig. 69). The dorsal area of the median lobe in ventral view is weakly sinuous and the basal part more robust (Fig. 70). The spermatheca (Fig. 72) is longer and thin, with a proportionally small apical lobe; the spermathecal duct is thin to the point of insertion with the spermatheca though there is a small expanded area just before the point of contact.

\section{Bathysciola (Bathysciola) (schiodtei group) fauveli Jeannel, 1924}

Bathysciola fauveli Jeannel, 1924. Arch. Zool. exp. gén., 63(1): 112

Bathysciola (Bathysciola) fauveli Jeannel: Perreau, 2000. Mém. de la SEF, 4: 236

Material StUdied. The original description indicates that only one male, designated "type" (Jeannel, 1924a) was studied. It is stored in the MNHNP general collection and is labelled: 1.: (hw) Venoix / (Calvados) inond.; 2.: (hw) schiodtei; 3.: (i, in red) TYPE; 4.: (hw) Adelops / crassipes / ab. n. sp.; 5.: (i) MUSÉUM PARIS / Coll. R. Jeannel 1931.

Male genitalia. Median lobe of aedeagus (Fig. 64) folded approximately in half, in an obtuse angle; basal half robust and dorsal face sinuous throughout. Tip of lateral style (Fig. 65) with four similar sinuous setae which are not very long. In the internal sac of the aedeagus (Fig. 63) there are some fine, strongly sclerotized phanerae next to the Y-shaped piece; in the median region the ventral phanerae are strongly sclerotized, as are the exterior ones, which are also very long; the dorsal phanerae are hyaline; the basal nodules in the phaneroid complex are slightly arquate, almost rectilinear.

Discussion. The male genitalia of the single specimen from Venoix in Calvados (France) was illustrated. The number of specimens studied is not indicated in the original description. The genitalia were prepared between two glass slides and one of the lateral style was separated; it was prepared again on an acetate paper slide and placed in Canada Balsam inserted on the same pin as the specimen it belongs to. Bathysciola fauveli was descri- 

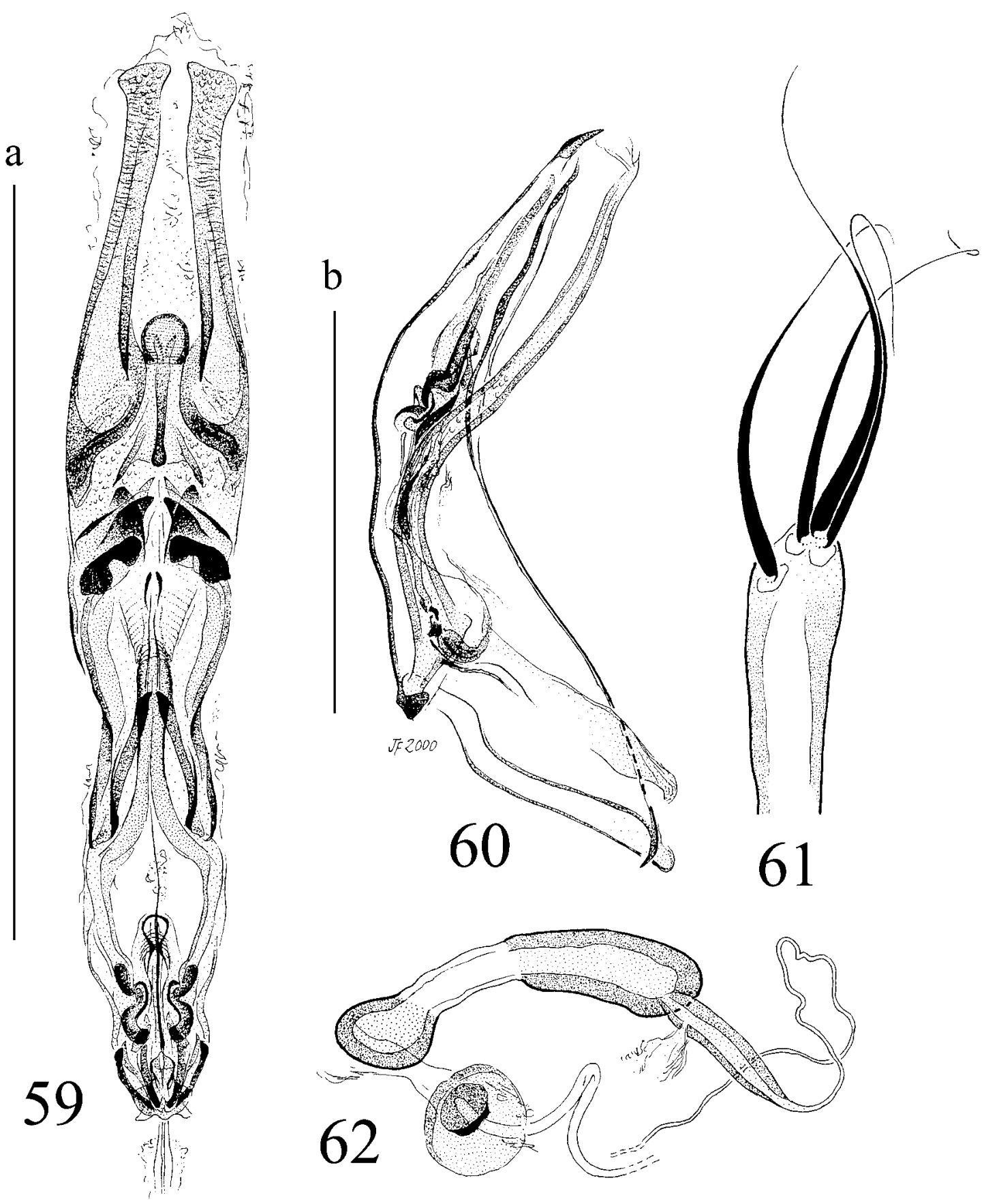

$\mathrm{c}$

Figs. 59-62.-Bathysciola (Bathysciola) diegoi. 59) internal sac of the aedeagus in dorsal view. 60) aedeagus in lateral view. 61) apical region of the lateral style. 62) spermathecal complex. Scale bar: a-b, $0.5 \mathrm{~mm}: 59,60$; c, $0.1 \mathrm{~mm}: 62$.

Figs. 59-62.- Bathysciola (Bathysciola) diegoi. 59) vista dorsal del saco interno del edeago. 60) vista lateral del edeago. 61) región apical del estilo lateral. 62) complejo espermatecal. Escala: a-b, $0.5 \mathrm{~mm}: 59,60$; c, $0.1 \mathrm{~mm}: 62$. 

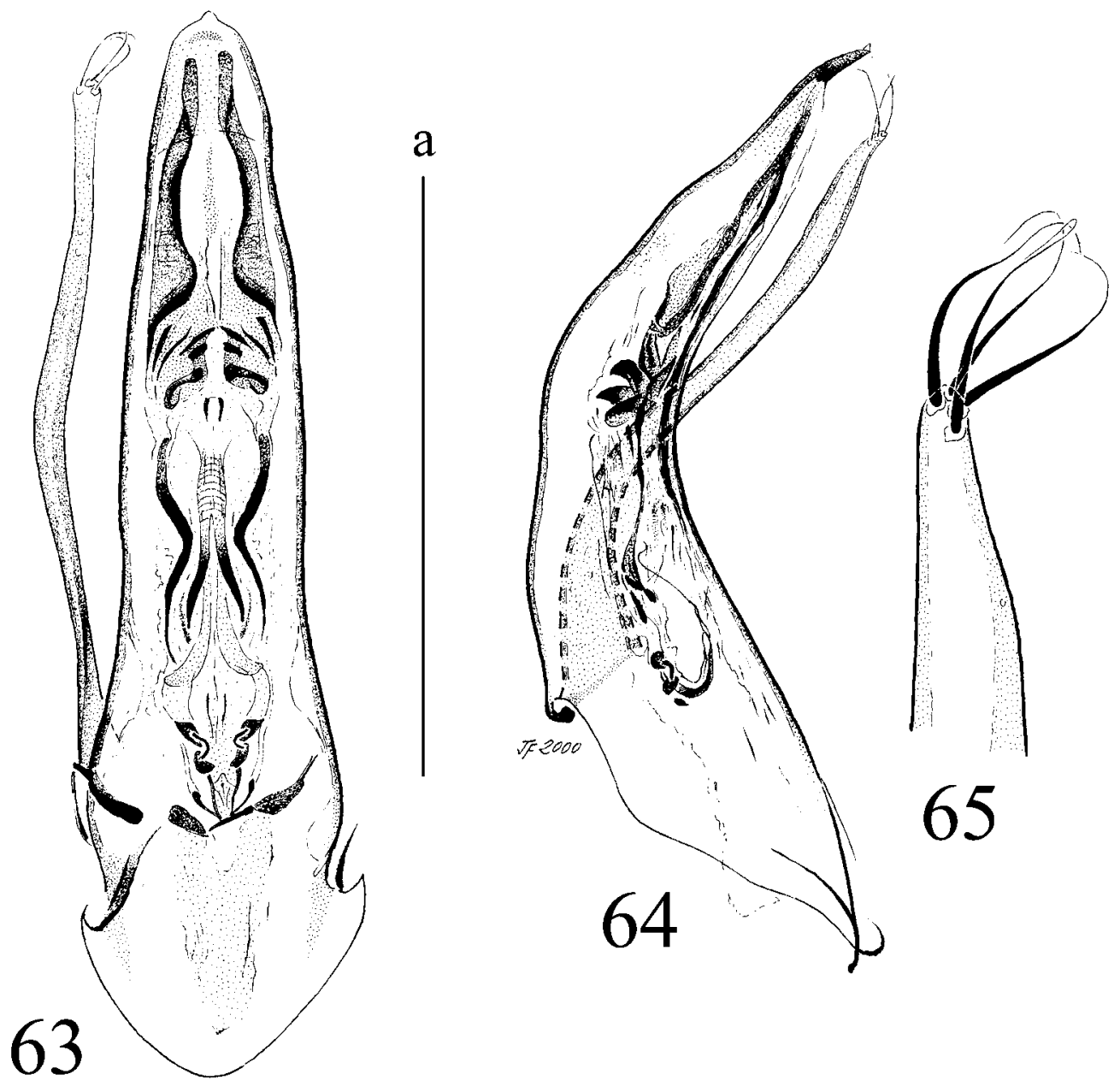

Figs. 63-65.- Bathysciola (Bathysciola) fauveli. 63) aedeagus and internal sac in dorsal view. 64) aedeagus in lateral view. 65) apical region of the lateral style. Scale bar: a, $0.5 \mathrm{~mm}: 63,64$.

Figs. 63-65.- - Bathysciola (Bathysciola) fauveli. 63) edeago y vista dorsal del saco interno. 64) vista lateral del edeago. 65) región apical del estilo lateral. Escala: a, 0.5 mm: 63, 64 .

bed in three lines of the identification key for the species belonging to genus Bathysciola proposed by Jeannel (1924a); in this paper the mentioned author relates the new taxon to $B$. rugosa due to characters of its external morphology. However, $B$. fauveli is closely related to $B$. schiodtei. The internal sac of the aedeagus was studied by transparency through the tegument of the median lobe; the reason for this was that extracting the sac meant destroying the median lobe and as this is a unique specimen it was decided that all the structures should be kept in tact. When there are more specimens the necessary preparations can be made to obtain more precise information. As far as can be seen the phaneroid complex of the upper part of the median region of the internal sac appears to be very similar to that of B. schiodtei without the upper nodules present in the latter species; in any case the internal sac of $B$. fauveli is certainly different to that of B. rugosa. Jeannel (1924a) states that there are three setae inserted in the tip of the lateral style. This is true of the left lateral style of the aedeagus in this specimen, but the right one has four; the left lateral style may have been mutilated; so, B. fauve$l i$ is considered to have four setae at the tip of the lateral style like the other species in the genus. 
Also, this specimen has a handwritten label that says schiodtei, which shows that the first impression of the person who studied the insect was to adjudicate this determination; this specimen was collected by A. Fauvel; it also has a handwritten label saying Adelops crassipes ab. n. sp., there is no proof that this name was ever published (there is a Mesocolon crassipes Szymczakowski, 1973 Paracatopinae-). Finally, it is interesting to note that this taxon came from an area considerably distant from the distribution area of this group of species.

\section{Bathysciola (Bathysciola) (schiodtei group) grandis} (Fairmaire, 1856)

Adelops grandis Fairmaire, 1856. Ann. Soc. entomol. Fr., 25: 525

Adelops depressus Saulcy, 1863. Ann. Soc. entomol. Fr. (Bull. séances), 32: 17

Bathyscia grandis (Fairmaire): Jeannel, 1907. Ann. Soc. entomol. Fr., 76: 424

Bathyscia (Bathyscia) grandis (Fairmaire): Jeannel, 1908. Arch. Zool. exp. gén., 4e série, 8: 313

Bathysciola schiodtei subsp. grandis (Fairmaire): Jeannel, 1910. Arch. Zool. exp. gén., 45(1): 29

Bathysciola (Bathysciola) schiodtei subsp. grandis (Fairmaire): Jeannel, 1914. Coleopterorum catalogus pars 60: 11

Bathysciola larcennei subsp. navarica Coiffait, 1959. Ann. Spéléol., 14(1-2): 160

Bathysciola (Bathysciola) schioedtei grandis (Fairmaire): Perreau, 2000. Mém. de la SEF, 4: 238

Material StUdied. The species was described from the Grotte d'Isturitz and the number of specimens studied is not indicated (Fairmaire, 1856). Several specimens belonging to the type series were found, stored in the MNHNP general collection and labelled: first specimen: 1.: (hw Fairmaire) Caverna / d'Isturitz / Bas-Pyr.; 2.: (i, in red) TYPE; 3.: (i) MUSÉUM PARIS / Coll. León Fairmaire / 1906; 4.: (hw Fairmaire) Bathyscia / grandis / Frm. Four more specimens preserved in the MNHNP general collection and labelled: first specimen: 1.: (i) Collection León Fairmaire / 1906; 2.: (hw Fairmaire) grandis / Frm / Grotte / d'Isturitz; 3.: (hw Jeannel) grandis / (in red) TYPE; 4.: (i) MUSÉUM PARIS / Coll. R. Jeannel 1931. Three specimens without "TYPE" red label: (hw Fairmaire) / Isturitz; 2.: (i) MUSÉUM PARIS / Coll. León Fairmaire / 1906.

Male genitalia. Median lobe of aedeagus (Fig. 67) folded in obtuse angle approximately in the middle; basal half strongly robust and dorsal face strongly sinuous throughout; the tip is strongly curved in the ventral part; the tip of the lateral style (Fig. 68) has two long setae and two shorter ones, all of them twisted. The internal sac of the aedeagus (Fig. 66) has a number of long, fine well sclerotized exterior phanerae; the ventral phanerae are very evident but the dorsal ones are practically invisible; the lower nodules in the phaneroid complex are fol- ded in an acute angle; amongst the reinforcing bands there are two laminas that do not come into contact, with a short tubule between them.

DisCUSSION. Specimens from Arudy, Basses Pyrénées (France) were used for the illustrations. It was described as a species (Fairmaire, 1856), but added to the subspecies of $B$. schiodtei (Jeannel, 1910). The peculiar features observed in the internal sac of its aedeagus in this study are sufficient to restore it to its original status of species. It should be included with those species exhibiting a tubule amongst the reinforcing bands of the internal sac. The most similar of these species is B. bigerrica $(B$. parallela would be slightly more distant) which has the same shaped basal nodules in the phaneroid complex and an almost identical tubule amongst the reinforcing bands; in $B$. bigerrica there is also a rod, which does not occur in $B$. grandis.

\section{Bathysciola (Bathysciola) (schiodtei group) obermaieri Bolívar, 1918}

Bathysciola (Bathysciola) obermaieri Bolívar, 1918. Bol. Soc. esp. Hist. nat., 18: 447

Bathysciola (Bathysciola) rugosa subsp. obermaieri Bolívar: Jeannel, 1924. Arch. Zool. exp. gén., 63(1): 112

Bathysciola rugosa ssp. obermaieri Bolívar: Español, 1966. Graellsia, 22: 17

Bathysciola (Bathysciola) schioedtei obermaieri Bolívar: Perreau, 2000. Mém. de la SEF, 4: 238

Material STUdied AND BIBLIOGRAPHICAL DATA. The number of studied species is not indicated in the original description (Bolívar, 1918). Several specimens belonging to the type series have been located in the MZB, MNCNM and MNHNP collections. A male specimen stored in col. MNCNM and labelled as follows: 1. (i) C. Santa Elena Biescas; 2. obverse (i): Prov. Huesca C. BOLIVAR, reverse (hw Bolívar): 24.VII.18; 3. (hw Bolívar) Bathysciola obermaieri C. Bol. TIPO. Three specimens, one male and two female, preserved in the MNCNM coll. and labelled as follows: 1. (i) C. Santa Elena Biescas; 2. obverse (i): Prov. Huesca C. BOLIVAR, reverse (hw Bolívar): 24.VII.18; 3. (hw Bolívar) Bathysciola obermaieri C. Bol. TIPO. Two specimens preserved in the MNHNP general collection and labelled: 1.: (i) C. Santa Elena Biescas; 2. obverse (i) Prov. Huesca C. BOLIVAR, reverse (hw Bolívar) 24.VII.18; 3. (hw Bolívar) Bathysciola obermaieri C. Bol. TIPO. A specimen preserved in col. MZB labelled: 1.: (i) C. Santa Elena / Biescas; 2. obverse (i): Prov. Huesca / C. BOLIVAR, reverse (hw Bolívar): 24.VII.18; 3. (i, r) COTYPUS; 4. (hw Bolívar) Bathysciola obermaieri / Co-TIPO C. Bol. / (i) C. BOLIVAR det. Additional material: S-HU, Villanúa, Cueva de las Guixas, 1962-63, Español, Senent, Auroux, Dumont, Barbier \& OE leg. (Escolà, 1974); S-HU, Villanúa, Cueva Nueva, Auroux \& OE leg. (Español, 1966); IX.1965, Auroux leg., 1 female (Español, 1966); 1962-63, Español, Senent, Auroux, Dumont, Barbier \& OE leg. (Escolà, 1974); S-HU, Villanúa, Cueva Vieja, OE, Senent, Auroux \& Español leg. 


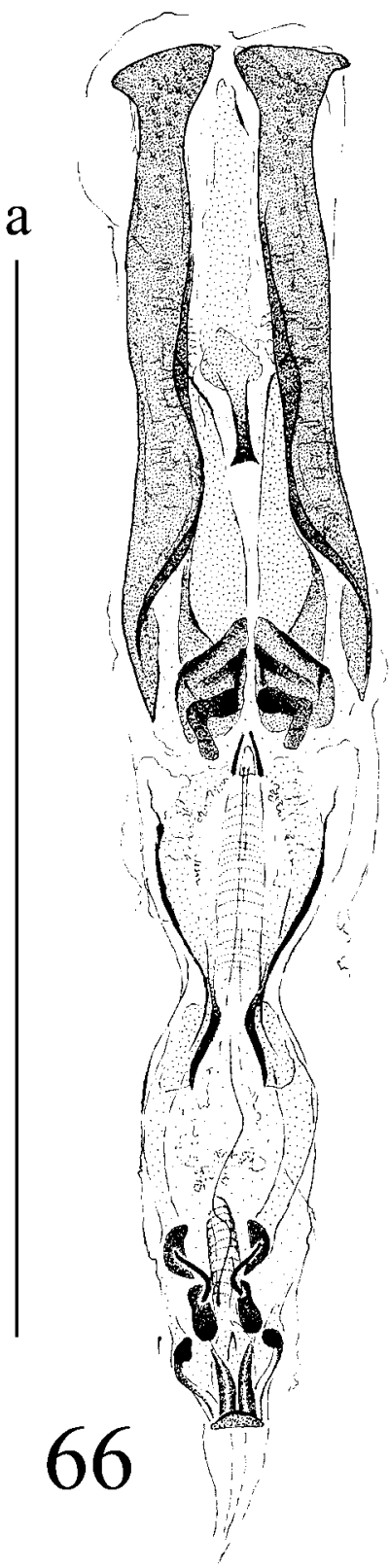

(Español, 1966); S-HU, Villanúa, Cueva del Rebeco, 20.8.1965, Auroux \& OE leg., 1 male (Español, 1966); S-HU, Villanúa, Cueva del Rebeco, 1962-63, Español, Senent, Auroux, Dumont, Barbier \& OE leg., (Escolà, 1974); S-SS, Orio, Guardetxe-Aurre'ko Leizea 1, Galán leg. (Español, 1970: subsp. rugosa; Escolà, 1974). The determination of the latter mentioned material need to be revised as its distribution area is at a considerable distance from the normal distribution of the species.

Male Genitalia. Median lobe of aedeagus (Fig. 70) folded in obtuse angle approximately in the middle; basal half strongly robust and dorsal face sinuous throughout; tip of lateral style (Fig. 71) with four long twisted setae of similar length, sometimes very long and twisted in a complicated manner. Internal sac of aedeagus (Fig. 69) with long robust exterior phanerae, though weakly sclerotized; phaneroid complex with rectilinear basal phanerae, upper end thin and basal thick, reforcing bands widened in basal region forming plates almost touching the axis of symmetry of the sac, where a tubule can be seen; near this a stout weakly 
sclerotised rod stretches from the apical tip of the reinforcing bands with a pubescent distal tip.

FEMALE GENITALIA. The spermathecal complex coincides with the description given for the genus, the spermatheca (Fig. 72) being long and thin.

Discussion. The genitalia of both sexes was illustrated using the specimens of the type series from the Cueva de Santa Elena, Biescas (Huesca). This taxon was described as a species (Bolívar, 1918) but added to the subspecific table of B. rugosa (Jeannel, 1924a). The peculiar features observed in the internal sac of the aedeagus are sufficient to restore it to its original status of species. Like $B$. diegoi -the most similar species- it belongs to the subgroup with a sclerotized structure amongst the reinforcing bands of the internal sac of the aedeagus; $B$. rugosa is not amongst them. The comparative examination of $B$. diegoi in the discussion section can be consulted.

\section{Bathysciola (Bathysciola) (schiodtei group) parallela} (Jeannel, 1907)

Bathyscia parallela Jeannel, 1907. Ann. Soc. entomol. Fr., 76: 422

Bathyscia (Bathyscia) parallela Jeannel, 1907: Jeannel, 1908. Arch. Zool. exp. gén., 4e série, 8: 317

Bathysciola parallela (Jeannel): Jeannel, 1910. Arch. Zool. exp. gén., 45(1): 29

Bathysciola (Bathysciola) parallela (Jeannel): Jeannel, 1914. Coleopterorum catalogus pars 60: 10

Bathysciola (Bathysciola) parallela parallela (Jeannel): Perreau, 2000. Mém. de la SEF, 4: 237

MATERIAL STUDIED. The original description indicates that only two males and two females have been studied (Jeannel, 1907); a male specimen belonging to the type series was found, stored in the MNHNP general collection and labelled: 1. (hw): Grotte de Rébénacq / B. Pyr. / 9-05; 2. (i): male; 3. (hw): 80; 4. (hw): parallela / TYPE (r); 5. (i): TYPE; 6. (i): MUSÉUM PARIS / Coll. R. Jeannel 1931.

Male Genitalia. Median lobe of the aedeagus in lateral view (Fig. 74) long, weakly arcuate, uniformly decreasing from base to tip, both faces strongly sinuous; lateral style almost as long as median lobe, pointed and bearing four strongly folded setae of similar length (Fig. 75); internal sac of aedeagus (Fig. 73) with weakly sclerotized phanerae next to Y-shaped piece; ventral phanerae in median region enormous, strongly sclerotized and forming the interior margin with translucent laminas; dorsal ones tiny and also strongly sclerotized; short phanerae along sides of sac, with only the lower pointed end sclerotized; basal nodules of phaneroid complex folded in very acute angle; inte- rior margin of reinforcement bands noticeably expanded and sclerotized, prolonged, forming enormous peduncles; robust rod amongst reinforcement bands.

Discussion. A series of specimens from the Grotte de l'Oueil du Neéz in Rébenacq, Basses Pyrénées (France) was used to illustrate the male genitalia. The description is very superficial as it is limited to a few lines in a dichotomic key (Jeannel, 1907). Its affinities must be looked for in the species of its group which have a sclerotized structure amongst the reinforcement bands of the internal sac of the aedeagus. B. bigerrica is the most similar and there is no doubt about its close relationship, they are the only species that have in common the unusual character of a pedunculate inferior end of the reinforcing bands. Many genital characters enable its identification (Figs. 51 and 73) though the difference in robustness, size and degree of sclerotization in the phanerae in the median region of the internal sac is probably the most apparent.

\section{Bathysciola (Bathysciola) (schiodtei group) rugosa} (Sharp, 1872)

Adelops rugosus Sharp, 1872. An. Soc. esp. Hist. nat., 1: 270 Bathyscia (Bathyscia) rugosa (Sharp): Reitter, 1885. Verh. Naturforsch. Ver. Brünn., 23(1884): 38

Bathyscia schioedtei subsp. rugosa (Sharp): Jeannel, 1907. Ann. Soc. entomol. Fr., 76: 424

Bathysciola rugosa (Sharp): Jeannel, 1910. Arch. Zool. exp. gén., 45(1): 29

Bathysciola (Bathysciola) rugosa (Sharp): Jeannel, 1914. Coleopterorum catalogus, pars 60: 11

Bathysciola (Bathysciola) rugosa (Sharp): Perreau, 2000. Mém. de la SEF, 4: 238

MATERIAL STUDIED AND BIBLIOGRAPHIC DATA. The original description does not indicate how many specimens were studied (Sharp, 1872). A specimen belonging to the type series has been found, stored in col. Brit. Mus. and labelled: 1. (i round red label): TYPE H.T.; 2. (hw): Alsasua G. R. C.; 3. (i): Sharp coll. 1905-313; 4. (hw Sharp): A. rugosus female type DS. The following specimens recorded by Jeannel (1911) and labelled as follows are in the Brit. Mus. collection: 1. (i): Alsasua Espagne R. Obr. \& L. Bl. Juin 1879; 2. (i): Brit. Mus. 1934680; 3.: (hw Jeannel) B. rugosa Sharp (i) Jeannel det. The following specimens are in the MNCNM collection: S-NA, Alsásua, Cueva de Orobe, 3.IX.1919, Bolívar leg., 1 male (Español, 1974; Español \& Bellés, 1980); S-NA, Alsásua, Escalera leg., 6 exs. (Escalera, 1899); S-NA, Alsásua, Uhagón leg., 1 male; S-SS, Zumaya, M. de la Escalera leg., 6 exs. (Escalera, 1899; Jeannel, 1911); S-SS, Albiztur, Cueva de Txorrote, 20.VIII.1919, Bolívar leg., 1 male (Español, 1974; Español \& Bellés, 1980); S-VI, Zuazo, M. de la Escalera leg., 4 females (Escalera, 1899). The following specimens are in the MNHNP general collection: S-NA, Alsásua, 1 ex.; S-NA, Alsásua, VI.1879, Oberthür \& Bleuze leg., 5 exs.; S-NA, Sierra 


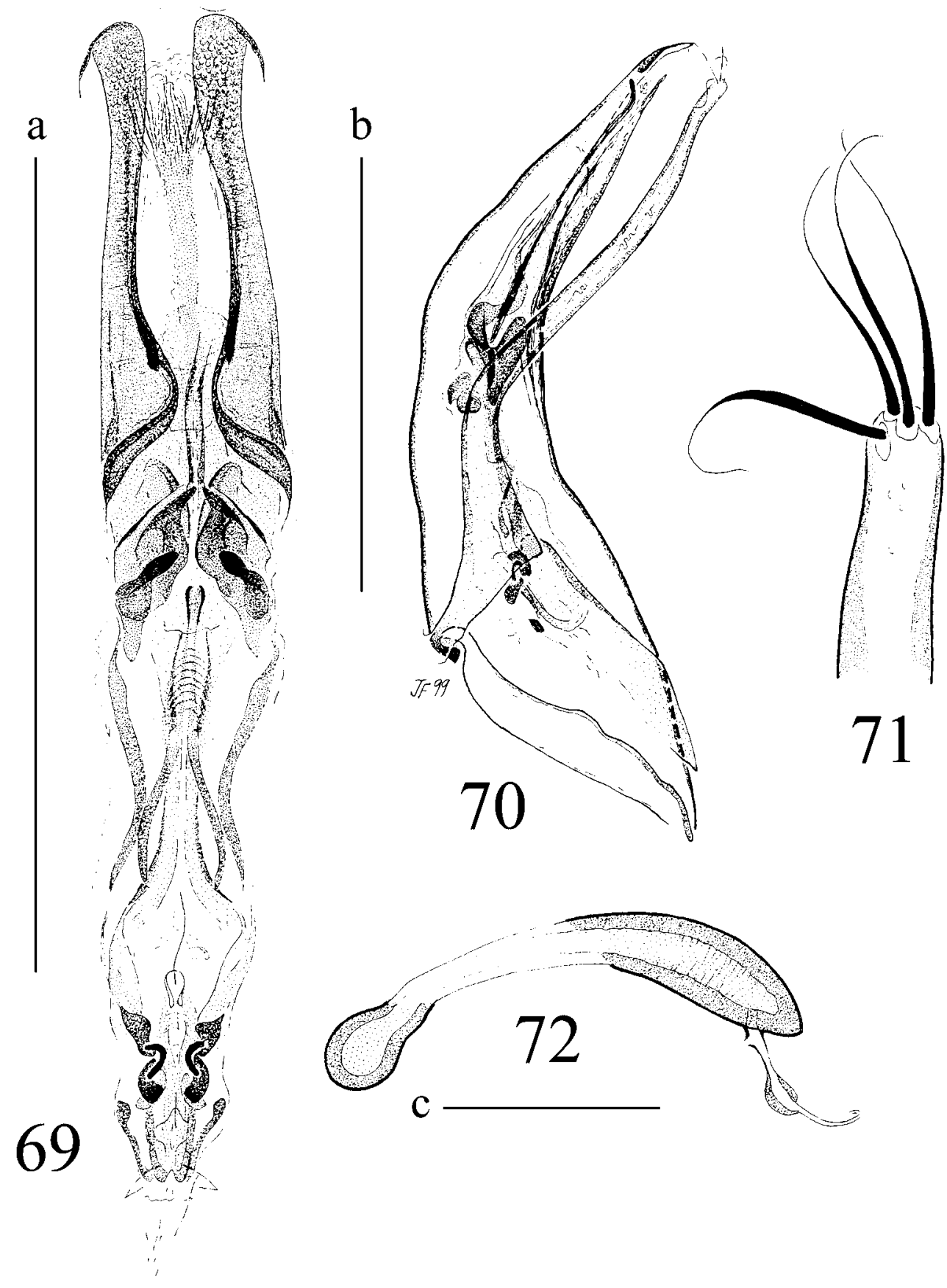

Figs. 69-72.- Bathysciola (Bathysciola) obermaieri. 69) internal sac of the aedeagus in dorsal view. 70) aedeagus in lateral view. 71) apical region of the lateral style. 72) spermatheca. Scale bar: a-b, $0.5 \mathrm{~mm}: 69,70$; c, $0.1 \mathrm{~mm}: 72$.

Figs. 69-72.-Bathysciola (Bathysciola) obermaieri. 69) vista dorsal del saco interno del edeago. 70) vista lateral del edeago. 71) región apical del estilo lateral. 72) espermateca. Escala: a-b, $0.5 \mathrm{~mm}: 69,70 ; \mathrm{c}, 0.1 \mathrm{~mm}: 72$. 


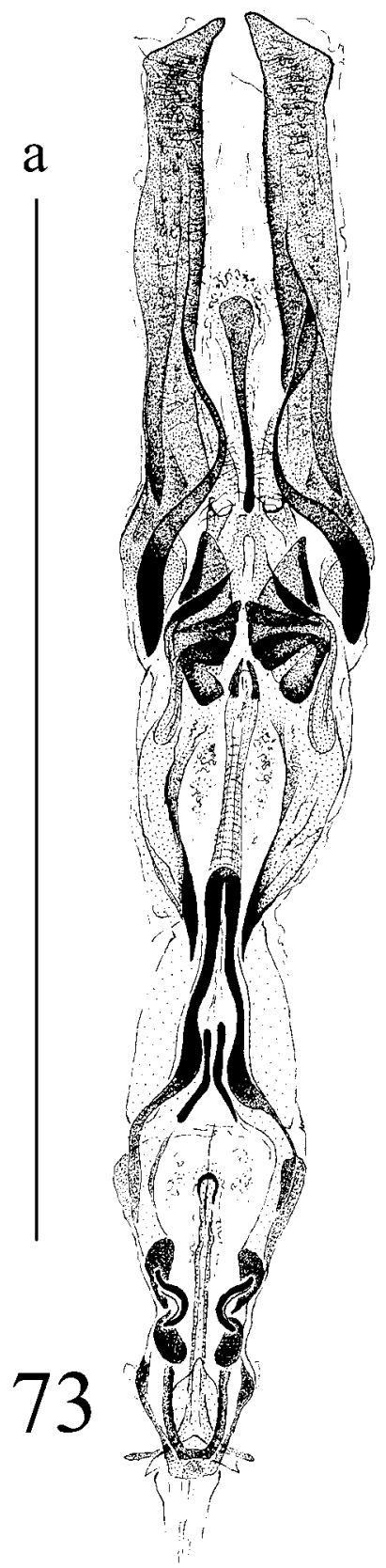

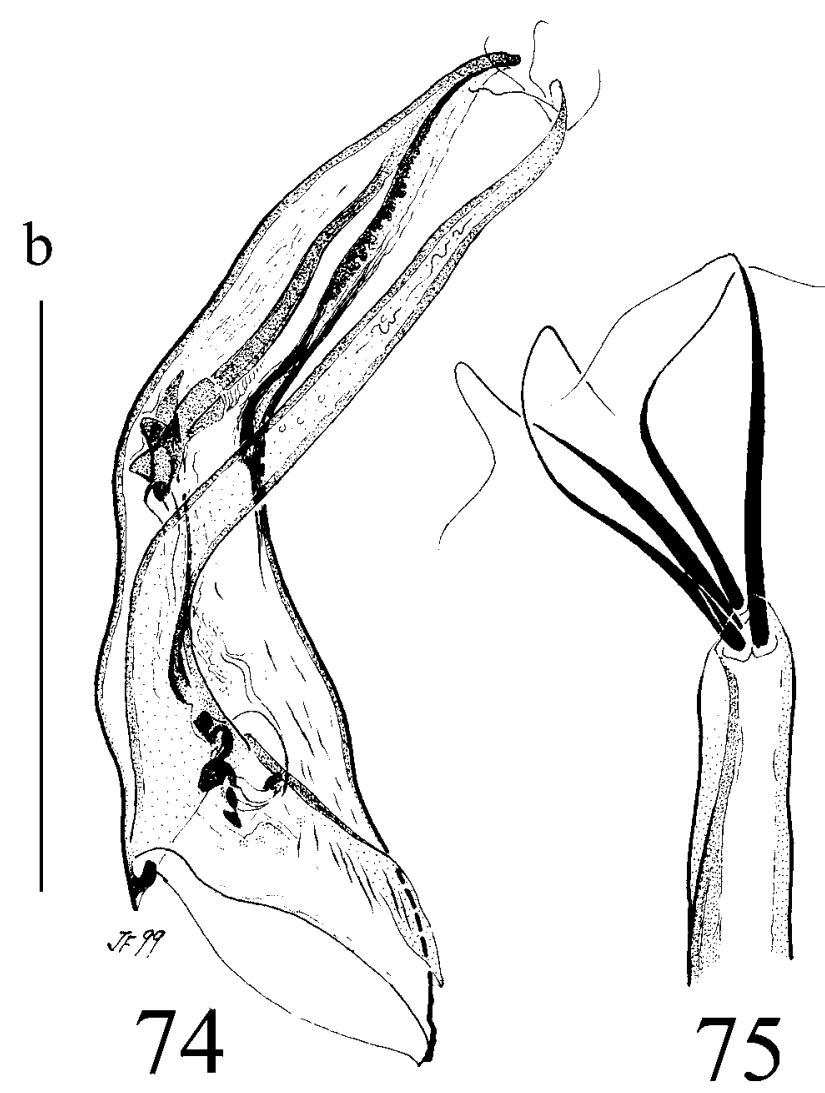

Figs. 73-75.-Bathysciola (Bathysciola) parallela. 73) internal sac of the aedeagus in dorsal view. 74) aedeagus in lateral view. 75 ) apical region of the lateral style. Scale bar: a-b, $0.5 \mathrm{~mm}: 73$, 74.

Figs. 73-75.- Bathysciola (Bathysciola) parallela. 73) vista dorsal del saco interno del edeago. 74) vista lateral del edeago. 75) región apical del estilo lateral. Escala: a-b, $0.5 \mathrm{~mm}$ : 73, 74.

Orobe 2, 16.VII.1998, Escoll \& Salgado leg., 3 males \& 8 females, stored in col. JF; S-NA, Villanueva de Aézcoa, Cueva de Artekia, VII.2000, Salgado \& JF leg., 1 male; S-VI, Zuazo, Uhagón leg. (Jeannel, 1911).

Male Genitalia. Median lobe of aedeagus (Fig. 77) folded in obtuse angle approximately in half; basal half propotionally weakly robust, dorsal face strongly sinuous throughout; tip of lateral style

(Fig. 78) bearing four long sinuous setae of two Peña de San Adrian, 2.IX.1919, RJ leg., 3 exs. The following also found in the Coiffait collection MNHNP: S-NA, Abaurrea Alta, Cueva del Puente, VII.1934, Gaudin leg., 1 ex. The following material has been studied an bibliographical references found: S-NA, Olazagutia, Cueva de Daran-Daran (Español, 1974; Español \& Bellés, 1980); S-NA Lekunberri, Casa Forestal de Aralar, 16.VII.1998, Salgado \& OE leg., 2 females, stored in col. JF; S-NA, Alsásua, Cueva de 
lengths. Internal sac of aedeagus (Fig. 76) with long fine strongly sclerotized phanerae with a laminar expanded area in upper extreme; phaneroid complex with basal phanerae folded in right angle; reinforcing bands expanding in basal region forming laminas that leave an empty space in the axial region of the sac.

Female Genitalia. Spermathecal complex (Fig. 79) coinciding with the description given for the genus, the spermatheca being proportionally short and robust.

DisCUSSION. The genitalia of both sexes were illustrated based on a series of specimens from the Cueva de Orobe, Alsásua (Navarra). This taxon was described as species (Sharp, 1872), but Coiffait (1959) tended to consider it as a large size subspecies of B. schiodtei, whose females are not distinguishable from those belonging to $B$. grandis -at that time considered as a subspecies of $B$. schiodte $i$ - The B. rugosa males are the largest of all the group and have such depressed elytra that they are almost flat. There are no differentiated structures in the reinforcement bands of the internal sac of the aedeagus, and the appearance of the basal nodules of the phaneroid complex place this taxon close to $B$. breuili, the most similar species. The characters differentiating these two species are detailed in the discussion section referring to $B$. breuili.

\section{Bathysciola (Bathysciola) (schiodtei group) schiodtei} (Kiesenwetter, 1850)

Bathyscia schiodtei Kiesenwetter, 1850: Stettiner entomol. Ztg., 11(7): 223

Adelops schiodtei (Kiesenwetter): Fairmaire et Laboulbène, 1854. Faune entomol. Fr., 1: 311

Bathyscia (Bathyscia) schioedtei Kiesenwetter: Reitter, 1885. Verh. naturforsch. Ver. Brünn, 23(1884): 32

Bathyscia schioedtei Kiesenwetter: Jeannel, 1907. Ann. Soc. entomol. Fr., 76: 423

Bathyscia (Bathyscia) schioedtei Kiesenwetter: Jeannel, 1908. Arch. Zool. exp. gén., 4e série, 8: 310

Bathysciola schiodtei (Kiesenwetter): Jeannel, 1910. Arch. Zool. exp. gén., 45(1): 28

Bathysciola (Bathysciola) schiodtei (Kiesenwetter): Jeannel, 1914. Coleopterorum catalogus, pars 60: 11

Bathysciola (Bathysciola) schioedtei schioedtei (Kiesenwetter): Perreau, 2000. Mém. de la SEF, 4: 239

Material STUdied AND BIBLIOGRAPHICAL DATA. The original description does not indicate the number of specimens studied and the specimen or the specimens of the type series have not been found in the investigations carried out in different museums. So, apart from the interpretation of the original description (Kiesenwetter, 1850), the characterisation of the species provided by different authors who state that they have identified the species (Bolívar, 1919; Jeannel 1911 \& 1924a;
Español, 1956; Coiffait, 1959) has been accepted. Numerous specimens of French origin determined by R. Jeannel and H. Coiffat deposited in the M NHNP collection, have been located and studied. The original description indicates the type locality: "Bagnières de Luchon" (Kisenwetter, 1850); different samplings carried out in the locality did not provide any specimens though some were found in a nearby locality; alter comparing them with the MNHNP specimens and verifying that it was the same species, they were used for the descriptions and illustrations in this study. The following material was studied and Iberian bibliographical references found: S-L, Bóssost (Español, 1956); S-L, Lés, III.1916, Hilaire leg. (Bolívar, 1919; Español, 1956); XI.1916, Hilaire leg. (Bolívar, 1919; Español, 1956); S-L, Vielha-Mijaran, Plan Batalher, 10.V.1999, JF leg., 3 males, stored in col. JF.; S-L, Val d'Aran, VIII.1916, Zariquiey leg. (Bolívar, 1919). The following specimens from the MNHNP general collection were studied: SL, Baix Aran, Bossost, 16.I.1916, Hilaire leg., 1 ex.; S-L, Baix Aran, Les, 16.I.1916, Hilaire leg., 1 ex. The following specimens are also in the Coiffait collection at the MNHNP: S-L, Baix Aran, Güells del Jueu, IX.1954, HC leg., 2 exs. The type series of $B$. larcennei navarica, junior synonymy of $B$. schiodtei schiodtei is in the Coiffait collection of the MNHNP. One specimen labelled: 1. (i): H. PYR, PIC D'ANIE / BOIS DE BRECA / 15-6-51 COIFFAIT; 2. (hw Coiffait): HOLOTYPE; 3. (i): MUSÉUM PARIS / 1985 / Coll. H. COIFFAIT; 4. (hw Secq, in red): s. sp. navarica / Holotype; 5. (hw Secq): Bathysciola / schiödtei / (Kiesenw.) / B. SECQ det. 1994. Another labelled: 1.: (hw Coiffait) 23.2.47 / (i) B. Pyrénées / (hw Coiffait) Arelte / (i) H. Coiffait; 2. (hw Coiffait): Aven / d'Ambielle; 3. (hw Coiffait): PARATYPE; 4. (i): MUSÉUM PARIS / 1985 / Coll. H. COIFFAIT; 5. (hw Secq, in red): s. sp. navarica / Coiffait / Paratype; 6. (hw Secq): Bathysciola / schiödtei / (Kisenw.) / B. SECQ det. 1994. There is also a third specimen determined by Coiffait as navarica which does not belong to the type series: F-B. Pyr., Bielle, Bois de Boila, 13.IX.1941, HC leg., 1 ex.

Male genitalia. The genital structures of $B$. schiodtei were used in the description of the genus; internal sac of the aedeagus (Fig. 80), aedeagus in lateral view (Fig. 81) and tip of the lateral style (Fig. 82).

Discussion. Bathysciola schiodtei belongs to the subgroup of species lacking tubules and rod amongst the reinforcing bands of the internal sac of the aedeagus. The most similar one is B. fauveli which also has straight, nocked basal nodules in the phaneroid complex, however, B. fauveli does not have the robust elongate upper nodules present in B. schiodtei.

\section{Incertae sedis}

\section{Bathysciola (Bathysciola) aranensis Coiffait, 1959}

Bathysciola aranensis Coiffait, 1959. Ann. Spéléol., 14(1-2): 162 Bathysciola (Bathysciola) aranensis Coiffait: Perreau, 2000. Mém. de la SEF, 4: 236 


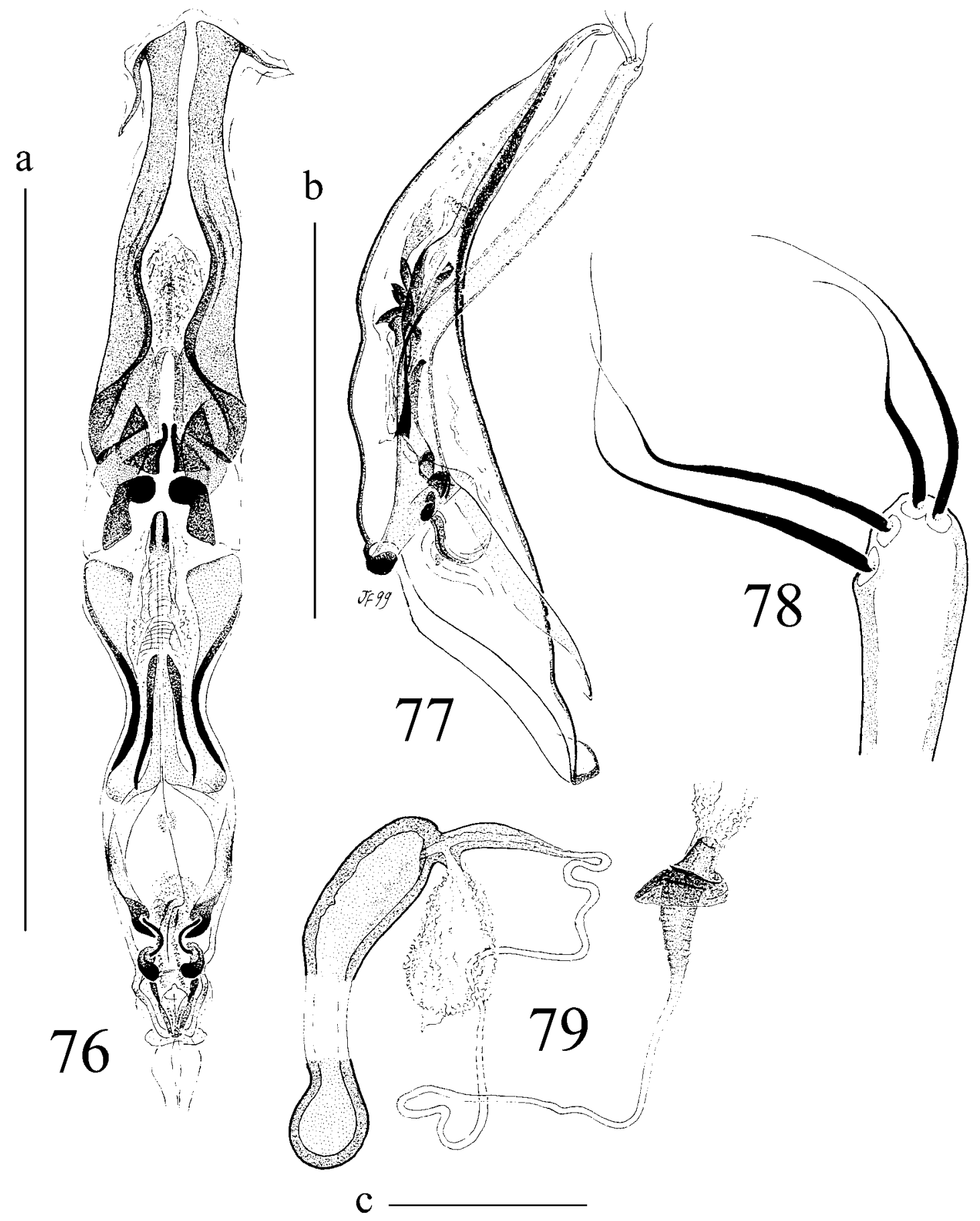

Figs. 76-79.- Bathysciola (Bathysciola) rugosa. 76) internal sac of the aedeagus in dorsal view. 77) aedeagus in lateral view. 78) apical region of the lateral style. 79) spermathecal complex. Scale bar: a-b, $0.5 \mathrm{~mm}: 76,77$; c, $0.1 \mathrm{~mm}: 79$.

Figs. 76-79.- Bathysciola (Bathysciola) rugosa. 76) vista dorsal del saco interno del edeago. 77) vista lateral del edeago. 78) región apical del estilo lateral. 79) complejo espermatecal. Escala: a-b, $0.5 \mathrm{~mm}: 76,77$; c, $0.1 \mathrm{~mm}: 79$. 

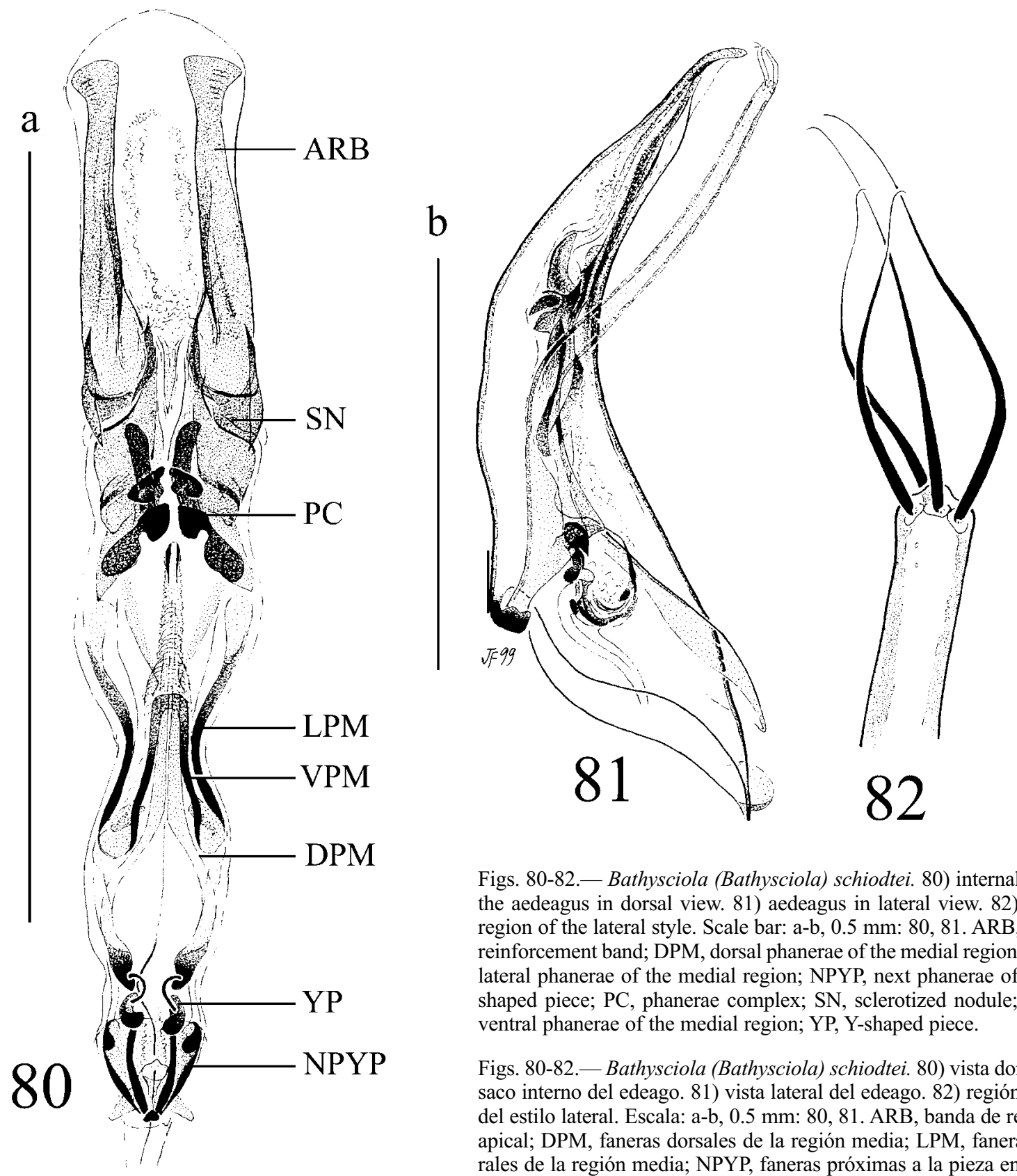

Figs. 80-82.-Bathysciola (Bathysciola) schiodtei. 80) internal sac of the aedeagus in dorsal view. 81) aedeagus in lateral view. 82) apical region of the lateral style. Scale bar: a-b, $0.5 \mathrm{~mm}$ : 80, 81. ARB, apical reinforcement band; DPM, dorsal phanerae of the medial region; LPM, lateral phanerae of the medial region; NPYP, next phanerae of the Yshaped piece; PC, phanerae complex; SN, sclerotized nodule; VPM, ventral phanerae of the medial region; YP, Y-shaped piece.

Figs. 80-82.-Bathysciola (Bathysciola) schiodtei. 80) vista dorsal del saco interno del edeago. 81) vista lateral del edeago. 82) región apical del estilo lateral. Escala: a-b, $0.5 \mathrm{~mm}: 80,81$. ARB, banda de refuerzo apical; DPM, faneras dorsales de la región media; LPM, faneras laterales de la región media; NPYP, faneras próximas a la pieza en forma de Y; PC, complejo de faneras; SN, nódulo esclorotizado; VPM, fanreas ventrales de la región media; YP, pieza en forma de Y.

No male from $B$. aranensis Coiffait, was studied; the related specimen in the description is a female and therefore it was not possible to determine the characters of its aedeagus; in the opinion of the person who described it this taxon is related to $B$. meridionalis (J. du Val) which also belongs to section VI of the genus Bathysciola, Jeannel (1924a). The number of specimens in the type series is not indicated in the original description: "Type: Val d'Aran,...", "Mâle inconnu." (Coiffait, 1959). The only female specimen was found in the Coiffait collection preserved at the MNHNP and is identified as a holotype labelled: 1. (hw Coiffait): Val d'Aran / Artiga de Lin / 9.54 H. Coiffait; 2. 
(hw Coiffait): aranensis / Coiff.; 3. (hw Coiffait, in red): HOLOTYPE.

Bathysciola (Bathysciola) ovata minuscula (Abeille de Perrin, 1901)

Bathyscia minuscula Abeille de Perrin, 1901. L'Echange, 17(201): 68

Bathysciola (Bathysciola) minuscula (Abeille): Jeannel, 1910. Arch. Zool. exp. gén., 45(1): 46

Bathysciola minuscula (Abeille): Jeannel, 1911. Arch. Zool. exp. gén., 47(1): 243

Bathysciola (Bathysciola) minuscula (Abeille): Jeannel, 1914. Coleopterorum catalogus pars 60: 10

Bathysciola (Bathysciola) ovata ssp. minuscula (Abeille): Jeannel, 1924. Arch. Zool. exp. gén., 63(1): 113

Bathysciola (Bathysciola) ovata minuscula (Abeille): Perreau, 2000. Mém. de la SEF, 4: 231

The number of specimens in the type series is not indicated in the original description (Abeille de Perrin, 1901). A specimen belonging to this series was found, deposited in the MNHNP collection and is labelled: 1 (i): Uriage /Grouvelle; 2 (i, r): TYPE; 3 (i): MUSEUM PARIS / Coll. ABEILLE de PERRIN / 1919; 4 (hw): minuscula. This taxon is found near Lyon, in the Rhône region, France. As the studied specimen is a female its identity and its proximity to other species have not been determined.

\section{Key to sections and species groups}

1. Internal sac of aedeagus with phanerae next to Y-shaped piece (Figs. 51, 54, 59, 63, 66, 69, 73, 76 and 80) section VI -part- or schiodtei group

* Internal sac of adeagus lacking phanerae next to Y-shaped piece (Figs. 1, 5, 8, 12, 15, 19, 22, 25, 28, 31, 45, 48, 34, 38 and 42 )

2. Tip of lateral style of adeagus with 3 (Figs. 3, 17, 21, 24 and 27), 5-6 (Fig. 14) or 8-14 setae (Figs. 7, 10 and 36); sac with striate tissue never present in upper part of median region of internal sac of the aedeagus .... (section IV) ... 3

* Tip of lateral style of aedeagus bearing 4 setae (Figs. 30, $33,40,44,47$ and 50); if there are 9 (Fig. 36), there is a sac with striate tissue in the upper part of the median region of the internal sac (Fig. 34) (section VI -part-) ... 6

3. Tip of lateral style of aedeagus with more than three setae (Figs. 7, 10 and 14)

* Tip of lateral style of aedeagus with 3 setae (Figs. 3, 17, 21, 24 and 27)

4. Tip of lateral style of aedeagus with 5-6 setae (Fig. 14) .... zariquieyi group: one species, B. zariquiey

* Tip of lateral style of aedeagus with 8-14 setae (Figs. 10 and 11) madoni group

5. Robust, denticulate strongly sclerotized axial piece in internal sac (Fig. 1)
* The axial piece either does not exist (Fig. 25) in the internal sac, or is very small, weakly sclerotized or hyaline, or only the shield of the distal extreme is visible (Figs. 15, 19 and 22) section VII or ovata group

6. Tip of lateral style of aedeagus bearing four tiny transversally lined setae (Figs. 30 and 33) .......... lapidicola group

* Tip of lateral style of aedeagus bearing four long (Fig. 44) or very long (Figs. 40, 47 and 50) setae; in exceptional cases, nine (Fig. 36)

7. A series of strongly sclerotized robust phanerae in the median region of the internal sac of the aedeagus, forming a type of ring with a nodule in the centre; the nodule is either simple, rounded (Fig. 42), elongate (Fig. 34), or T-shaped (Fig. 38) ...................................... meridionalis group

* Very fine, weakly sclerotized dorsal and ventral phanerae in the median region of the internal sac of the aedeagus (Figs. 45 and 48 )

larcennei group

\section{Key to madoni group}

1. Median lobe of aedeagus in lateral view uniformly arquate from one end to the other, of fairly uniform thickness, even in apical third (Fig. 6)

B. madoni

* Median lobe of aedeagus in lateral view arquate in basal two thirds, a thick area, whereas the apical third is sinuous and gradually decreasing to tip; small depression on dorsal face; distal extreme slightly prolonged and peak shaped (Fig. 9)

B. penicillata

\section{Key to ovata group}

1. Mesosternal carina prolonged on metasternum; apical reinforcing bands in internal sac of aedeagus (Fig. 15) resting upon two membranous bands covered in fine long spines; two triangular phanerae with expanded interior margin and bearing a number of strongly robust spines ........ B. ovata

* Mesosternal carina not prolonged on metasternum; apical reinforcing bands of internal sac of aedeagus (Figs. 19, 22 and 25) not resting upon any differentiated structure; two rounded phanerae very close together or joined by their internal margin ................................................................ 2

2. First segment of male protarsi much wider than distal extreme of protibia and heart-shaped. Lateral style of aedeagus very thick throughout (Fig. 26) with strongly expanded club-shaped distal area (Fig. 27); tissue covered in thick spines near Y-shaped piece in internal sac of aedeagus (Fig. 25) .................................................... B. talpa

* First segment of male protarsi more or less as wide as distal extreme of protibia. Lateral style of aedeagus much thinner throughout, distal area very thin (Fig. 21) or slightly expanded (Fig. 24); near Y-shaped piece in the internal sac of the aedeagus, no differentiated structure (Fig. 19) or membranous sac covered in round scales (Fig. 22)

3. Median lobe of aedeagus in lateral view rectilinear in basal region, but in the rest, smooth and uniformly curved to the tip, which is pointed (Fig. 20); internal sac of aedeagus (Fig. 19) with one small elongate bifurcate nodule in 
median region, in axial position; reinforcing bands very long in apical region .................................... B. asperula

* Median lobe of aedeagus in lateral view uniformly arquate from base to apical third; sinuous from this point on, pointed tip slightly expanded and curved (Fig. 23); internal sac of aedeagus (Fig. 22) with two small elongate phanerae almost touching in the axial line of the sac and set out on a round lamina; reinforcing bands short in apical region ....

B. simonis

\section{Key to lapidicola group}

1. Aedeagus in lateral view (Fig. 29) lacking ventral expanded area; in dorsal view sides converging to tip

B. arcuatipes

* Aedagus in lateral view (Fig. 32) with ventral expanded area in upper end of basal region; in dorsal view stout, with almost parallel sides, weakly converging to little truncate tip

B. lapidicola

\section{Key to meridionalis group}

1. Tip of lateral style of aedeagus with nine setae (Fig. 36) .. B. finismillennii sp. $\mathrm{n}$. Tip of lateral style of aedeagus with four setae (Figs. 40 and 44)

2. Upper end of median region of internal sac of aedeagus bearing a lamina as wide as sac itself, formed by a strongly striate tissue (Fig. 42)

B. meridionalis

* Upper end of median region of internal sac of aedeagus without similar structures observed, at most with one axial piece sometimes envelopped in slightly striate tissue (Fig. 38)

B. grenieri

\section{Key to larcennei group}

1. Tip of lateral style of aedeagus with 4 long setae and membranous lamina; two glabrous phanerae joined by a sclerotized bridge at base of reinforcing bands of internal sac of aedeagus (Fig. 48)

B. larcennei

* Tip of lateral style of aedeagus with 4 long setae, lacking membranous lamina; two densely pubescent isolated phanerae at base of reinforcing bands of internal sac of aedeagus (Fig. 45)

B. convena new rank

\section{Key to schiodtei group}

1. Clearly defined, strongly sclerotized structure amongst reinforcing bands of internal sac of aedeagus: tubule (Figs. 66 and 69), rod (Figs. 59 and 73), or a combination of both (Fig. 51)

* No well sclerotized clearly differentiated structure amongst reinforcing bands of internal sac of aedeagus (Figs. 54, 63, 76 and 80)

... 6

2. Basal nodule of phaneroid complex of internal sac of aedeagus folded in acute angle (Figs. 51, 66 and 73) ............ 3
* Basal nodule of phaneroid complex of internal sac of aedeagus rectilinear, with inferior margin (Fig. 59) or nocked upper one (Fig. 69) ……................................................ 5

3. Internal sac of aedeagus (Fig. 73): basal nodule of phaneroid complex folded in very acute angle so that internal margin of both segments of angle almost touching; large strongly sclerotized rod amongst reinforcing bands; in inferior region of reinforcing bands a number of enormous strongly sclerotized penduncles; ventral phanerae very long, robust and strongly sclerotized ............ B. parallela

* Internal sac of aedeagus (Figs. 51 and 66): basal nodule of phaneroid complex folded in acute angle close to $90^{\circ}$; short tubule amongst reinforcing bands with a fine rod inside; in inferior region of reinforcing bands a number of small weakly sclerotized penduncles; ventral phanerae very short and thin

4. Tip of lateral style of aedeagus with 4 subequal setae (Fig. 53). Internal sac of aedeagus (Fig. 51), tiny tubule amongst reinforcing bands inside with there is a fine rod; lateral phanerae of median region short, weakly sclerotized with extremes expanded in a spatula shape

B. bigerrica new rank

* Tip of lateral style of aedeagus with 2 very long setae and two shorter ones (Fig. 68). Internal sac of aedeagus (Fig. 66), small tubule only amongst reinforcing bands; lateral phanerae of median region fine, long and well sclerotized

B. grandis

5. Internal sac of aedeagus (Fig. 69): in phaneroid complex upper phanera forming triangular lamina with two expanded margins; intermediate phanera elongate, upper margin expanded, protruding to axial line of sac; ventral and lateral phanerae more slender and weakly sclerotized. Median lobe in lateral view with dorsal area weakly sinuous and basal part more robust (Fig. 70). Spermatheca (Fig. 72) longer and thin, with apical lobe proportionally small; spermathecal duct thin to point of insertion with spermatheca though with small expanded area just before point of contact

B. obermaieri

* Internal sac of aedeagus (Fig. 59): in phaneroid complex upper phanera is a simple triangular lamina; intermediate phanera is shaped like a triangular tooth and is also a flat lamina; ventral and lateral phanerae strongly sclerotized and robust. Median lobe in lateral view with dorsal region more sinuous and basal portion less robust (Fig. 60). Spermatheca (Fig. 62) shorter and robust, with proportionally larger apical lobe; spermathecal duct inserted in spermatheca through a large elongate nodule

B. diegoi

6. Basal nodules of internal sac of aedeagus not folded in half therefore looking subrectilinear (Figs. 63 and 80) .......... 7

* Basal nodules of internal sac of aedeagus strongly folded in the middle forming obtuse (Fig. 76) or even acute (Fig. 54) angle

7. Large strongly sclerotized elongate upper nodules visible in phaneroid complex of internal sac of aedeagus (Fig. 80) ..

B. schiodtei

* Nodules not visible in phaneroid complex of internal sac of aedeagus (Fig. 63) B. fauveli 
8. Male metafemurs with denticle in posterior margin. In the internal sac of the aedeagus (Fig. 54) the two upper phanerae in the phaneroide complex are superposed, one on top of the other, so that only the apical vertex of the upper one can be seen; outer phanerae in the median region thin and weakly sclerotized

B. breuili

* Male metafemurs lacking denticle in posterior margin. In the internal sac of the aedeagus (Fig. 76) the two upper phanerae in the phaneroid complex are at a distance from each other, so that the entire surface of both can be seen; outer phanerae in the median region fine, strongly sclerotized and expanded at upper end forming weakly sclerotized lamina

B. rugosa

\section{References}

Abeille de Perrin, E., 1901. Nouvelles espèces de Coléoptères français. L'Echange, 17(201): 68-70.

Bellés, X., 1983. Descripción de un nuevo Bathysciinae ibérico y algunas notas sobre el valor específico de los caracteres del saco interno del edeago. Fragmenta Entomologica, 17(1): 105-110.

BELlÉs X., 1984. Estudi de l'armadura genital en les poblacions de Speonomus (Parvospeonomus) delarouzeei s. 1. i S. (P.) vilarrubiasi Zariquiey (Coleoptera, Catopidae, Bathysciinae) que conviuen a la Cova del Far (Susqueda, La Selva). Exploracions, 8: 7-13.

BEllés, X. \& COMAs, J., 1986. Estudi del sac intern de l'edeagus dels Speonomus del subgènere Speonomites Jeannel, i de Speonomus colominasi Zariquiey (Coleoptera, Catopidae, Bathysciinae). Exploracions, 10: 43-45.

Bellés, X., Comas, J., EscolÀ, O. \& Español, F. 1978. Los Bathysciinae ibéricos: Propuesta de ordenación taxonómica (Col. Catopidae). Speleon, 24: 59-68.

Bolívar, C., 1918. Una Bathysciola cavernícola nueva de la vertiente española de los Pirineos (Col. Silphidae). Boletín de la real Sociedad española de Historia natural, 18: 447-449.

Bolívar, C., 1919. Nota sobre tres Bathysciola de Cataluña (Col. Silphidae). Butlletí de l'Institució Catalana d'Història natural, 19: 18-21.

Bolívar, C., 1921. Coleópteros cavernícolas nuevos de las provincias vascas. Boletín de la real Sociedad española de Historia natural, tomo del cincuentenario: $524-539$

Casale, A., Giachino, P. M. \& Vailati, D., 1991. Brevi considerazioni per una sistematica dei Bathysciinae (Coleoptera: Cholevidae). Atti del XVI congreso nazionale italiano di Entomologia, Bari-Martina Franca: 857-865.

CoIfFAit, H., 1959. Note sur les Bathysciitae de la région Pyrénéenne et de Catalogne. Annales de Spéléologie, 14(1-2): 159-179.
Comas, J., 1983. Los diferentes modelos de sacos internos de las especies del género Anillochlamys Jeannel (Col. Bathysciinae). Mémoires de Biospéologie, 10: 245-247.

Comas, J. \& EscolÀ, O., 1989. El saco interno de los Troglophyes del sur de los Pirineos (Col. Catopidae, Bathysciinae). Mémoires de Biospéologie, 16: 141143 .

Dupré, E., 1989. Bathysciinae (Col. Catopidae) des Pyrénées Occidentales: I Étude du sac interne et morphologie comparée des Speonomus de la région de StJean-Pied-de-Port, redéfiniton du sous-genre Phacomorphus et création du sous-genre Phacomorphoides, considérations phylogéniques et biogéographiques locales, considérations générales sur la systhématique des Bathysciinae. Ikartzaleak, 13: 55-99.

DuPré, E., 1990. Bathysciinae (Col. Catopidae) des Pyrénées Occidentales: II. Étude et morphologie comparée du sac interne de l'édeage des Speonomus et genres voisins des sierras de Navarre et Guipuzkoa. Considérations phylogéniques et biogéographiques locales. Ikartzaleak, 14: 57-72.

DUPRÉ, E., 1991. Bathysciinae nouveaux de la Navarre Pyreneenne (Espagne) (Col. Bathysciinae). Mémoires de Biospéologie, 18: 269-273.

Dupré, E., 1992. Analyse comparée du sac interne de Bathysciinae (Coleoptera Catopidae): interet taxinomique, considérations sur l'evolution fonctionelle du sac. Mémoires de Biospéologie, 19: 169-186.

ESCALERA DE LA, M., 1899. Examen del grupo Bathysciae de España. Anales de la Sociedad española de Historia natural, 28: 363-412.

EscolÀ, O., 1974. Los Bathysciinae de Aragón. Comunicacions del IV Simposi de Biospeleologia. Comité Catalano-Balear de Espeleología, Barcelona: 13-20.

ESPAÑOL, F., 1956. Los Bathysciinae catalanes. Actes $d u 2$ Congrés International d'Etudes Pyrénéens, LuchonPau, 3(2): 109-123.

EsPaÑol, F., 1966. Dos años de actividades bioespeleológicas en el N.E. de España. Coleópteros. Graellsia, 22: $13-23$.

EsPaÑol, F., 1970. Un nuevo Bathysciinae cavernícola de Guipúzcoa (Col. Catopidae). Speleon, 17: 59-62.

EsPAÑoL, F., 1974. Los Bathysciinae cavernícolas de Vizcaya, Guipúzcoa y vecinos relieves navarros. (Col. Catopidae). Kobie, 5: 7-16.

Español, F. \& Bellés, X., 1980. Coleoptera Catopidae Bathysciinae. In: Contribución al conocimiento de la fauna cavernícola del País Vasco. Kobie, 10: 557-561.

FAIRMAIRE, L., 1856. Miscellanea Entomologica. Annales de la Société entomologique de France, 25: 517-548.

FAIRMAIRE, L., 1857. Miscellanea Entomologica. Deuxième partie. Annales de la Société entomologique de France, 26: 725-745. 
FresnedA, J., 1998. Revisión de los géneros de Leptodirinae de la sección Speonomus del sur de Pirineos: géneros Antrocharidius Jeannel 1910, Perriniella Jeannel 1910, Speonomus Jeannel 1908, Troglocharinus Reitter 1908 y Troglophyes Abeille 1894 (Coleoptera, Cholevidae). Mémoires de Biospéologie, 25: 53-85.

Fresneda, J. \& Hernando, C., 1994. Descripción de Bellesia n. gen. (Col. Cholevidae) del Pirineo de Huesca (España) y consideraciones sobre las estructuras del saco interno del edeago. Mémoires de Biospéologie, 20(47): 57-62.

Fresneda, X., Hernando, C. \& Lagar, A., 1994. Contribució al coneixement de Speonomus eseranus Lagar, 1974 (Col., Cholevidae, Leptodirinae) i descripció del subgénere Naspunius nov. Bolletí de la Societat d'Història natural de les Balears, 37: 109-116.

Fresneda, J. \& Salgado, J. M., 2000. Revisión de los géneros de Leptodirinae de la sección Speonomus del sur de Pirineos, II: géneros Aranzadiella Español 1972, Euryspeonomus Jeannel 1919, Kobiella Español \& Bellés 1980 y Speocharidius Jeannel 1919 (Coleoptera, Cholevidae). Mémoires de Biospéologie, 27: 41-52.

Fresneda, J., Salgado, J. M. \& Ribera, I., (in press). Phylogeny of Western Mediterranean Leptodirini, with an emphasis on genital characters (Coleoptera: Leiodidae: Cholevinae). Systematic Entomology.

Giachino, P. M., 1998. Una nuova Bathysciola del Caucaso (Coleoptera Cholevidae: Leptodirinae). Annali del Museo civico di Scienze Naturali di Brescia, [1995], 31: 105-112.

Giachino, P. M., Vailati, D. \& Casale, A., 1998. Major questions in the phylogeny and biogeography of Cholevidae (Coleoptera), with emphasis on the subfamily Leptodirinae. In: Phylogeny and Evolution of Subterranean and Endogean Cholevidae (= Leiodidae Cholevinae), proceedings of XX I.C.E. Firenze, 1996. Atti del Museo regionale di Scienze naturali, Torino: 179-209.

GuÉORguiev, V., 1974a. Sur la classification de la sousfamille des Bathysciinae (Catopidae, Coleoptera). Comptes-rendus de l'Académie bulgare des Sciences, 27(6): 839-842.

GuÉORGUIEv, V., 1974b. Idées nouvelles sur la phylogénie et la palézoographie de la sous-famille des Bathysciinae. Comptes-rendus de l'Académie bulgare des Sciences, 28(7): 965-968.

GuÉORGUIEV, V., 1976. Recherches sur la taxonomie, la classification et la phylogénie des Bathysciinae (Col. Catopidae). Razprave 4, razreda SAZU, 19(4): 91-129.

Hustache, A., 1913. Variations observées sur quelques Bathysciinae (Col.). Bulletin de la Société entomologique de France, 18: 85-86.

JACQUELIN DU VAL, C., 1854. ommunications: séance du 28-juin 1854. Annales de la Société entomologique de France (Bulletin des Séances), 23: 36-37.
JEANNEL, R., 1907. Étude des Bathyscia du groupe de $B$. Schiödtei Kiesw. Annales de la Société entomologique de France, 76: 419-424.

JEANNEL, R., 1909. Coléoptères cavernicoles nouveaux ou peu connus des Pyrénées (note préliminaire). Bulletin de la Société entomologique de France, 14: 17-20.

JEANNEL, R., 1910. Essai d'une nouvelle classification des Silphides cavernicoles. Archives de Zoologie expérimentale et générale, 45(1): 1-48.

JEANNEL, R., 1911. Révision des Bathysciinae (Coléoptères, Silphides). Morphologie, distribution géographique, systématique. Archives de Zoologie expérimentale et générale, 47(1): 1-641.

JEANNEL, R., 1922. La variation des pièces copulatrices chez les Coléoptères. Comptes-rendus de l'Académie des Sciences de Paris, 174: 324-326.

JEAnNel, R., 1923. Un nouveau Bathysciola des PyrénéesOrientales. Bulletin de la Société entomologique de France, 28: 104-106.

JEANNEL, R., 1924a. Monographie des Bathysciinae. Archives de Zoologie expérimentale et générale, 63(1): 1-436.

JEANNEL, R., 1924b. Coléoptères nouveaux de Catalogne. Treballs del Museu de Ciències naturals de Barcelona, 4(8): 1-18.

JEANNEL, R., 1930. Diagnoses préliminaires de quelques Bathysciinae nouveaux. Bulletin de la Société entomologique de France, 35: 223-229.

JEANNEL, R., 1950. Coléoptères cavernicoles nouveaux de France avec un étude sur la phylogénie des Speonomus. Notes Biospéologiques, 5: 83-95.

JEANNEL, R., 1955. L'édéage, initiation aux recherches sur la systématique des Coléoptères. Publications $d u$ Muséum national d'Histoire naturelle de Paris, 16 : 1-155.

Kiesenwetter, H. von, 1850. Fünfzig Diagnosen unbeschriebener oder wenig bekkanter europäischen Käfer. Stettiner entomologische Zeitung, 11(7): 217225.

Lagar, A., 1954. Los Bathysciitae (Col. Catopidae) de la provincia de Barcelona. Speleon, 5: 247-259.

LANEYRIE, R., 1967. Nouvelle classification des Bathysciinae (Col. Catopidae). Tableaux des soustribus, groupes de genres et genres. Annales de Spéléologie, 22(3): 585-645.

LANEYRIE, R., 1969. Addenda et corrigenda á la «Nouvelle classification des Bathysciinae». Annales de Spéléologie, 24(4): 733-736.

LANEYRIE, R., 1978. A propos d'une nouvelle classification des Bathysciinae. Nouvelle Revue d'Entomologie, 8(1): 51-52.

Perreau, M., 1989. De la phylogénie des Cholevidae et des familles apparentées (Coleoptera, Cholevidae). Archives des Sciences, Genève, 39(3): 579-590. 
Perreau, M., 2000. Catalogue des Coléoptères Leiodidae Cholevinae et Platypsillinae. Mémoires de la Société entomologique de France, 4: 1-460

Peyerimhoff, P., 1905. Etude sur les Bathyscia du groupe d'Aubei Kies. (Col.). Bulletin de la Société entomologique de France, 10: 297-303.

Salgado, J. M., 1975. Nueva revisión sistemática y distribución geográfica de los Bathysciinae (Coleoptera) cavernícolas de los Montes Cantábricos. Tesis doctoral. Universidad de Oviedo: 1-234 (inédita).

Salgado, J. M., 1993. Los Bathysciinae (Col. Cholevidae) cantábricos: «sección Speocharis». Mémoires de Biospéologie, 20: 221-230.

SAlgado, J. M., 2000. A new revision and taxonomic position for the Cantabrian Leptodirinae: sections Quaestus and Speonomidius (Coleoptera: Cholevidae). Annales de la Société entomologique de France (N.S.), 36(1): 45-59.

Salgado, J. M. \& Fresneda J., 2000. Bathysciola diegoi sp. n. (Coleoptera: Cholevidae: Leptodirinae) de Navarra (España). Elytron, 14: 183-189.

SAlgado, J. M. \& Fresneda, J., 2003. Revision of the section Anillochlamys Jeannel, 1909 (Coleoptera: Leiodidae: Cholevinae: Leptodirini). Annales de la Société entomologique de France (N.S.), 39(4): 361384.
SECQ, B. \& SecQ, M., 1996. Étude sur le genre Bathysciola Jeannel de la région pyrénéenne (Col. Cholevidae). L'Entomologiste, 52(1): 9-16.

SHARP, D., 1872. Descripciones de algunas especies nuevas de Coleópteros. Anales de la Sociedad española de Historia natural, 1: 259-271.

Vailati, D., 1988. Studi sui Bathysciinae delle Prealpi Centro-occidentali. Revisione sistematica, ecologia, biogeografia della «serie filetica di Boldoria» (Coleoptera, Catopidae). Monografie di «Natura Bresciana», 11: 1- 331.
Recibido, 22-XII-2005

Aceptado, 15-V-2006 Publicado, 30-VI-2006 